U.S. Department of Energy

Idaho Operations Office

\title{
FY 2012 INL Site Sustainability Plan with the FY 2011 Annual Report
}

January 2012 
(This Page Intentionally Left Blank) 
DOE/ID-11383

Revision 3

\section{FY 2012 INL Site Sustainability Plan with the FY 2011 Annual Report}

January 2012

Prepared for the

U.S. Department of Energy

DOE Idaho Operations Office 
(This Page Intentionally Left Blank) 


\title{
FY 2012 INL Site Sustainability Plan with the FY 2011 Annual Report
}

\author{
DOE/ID-11383
}

Revision 3

January 2012
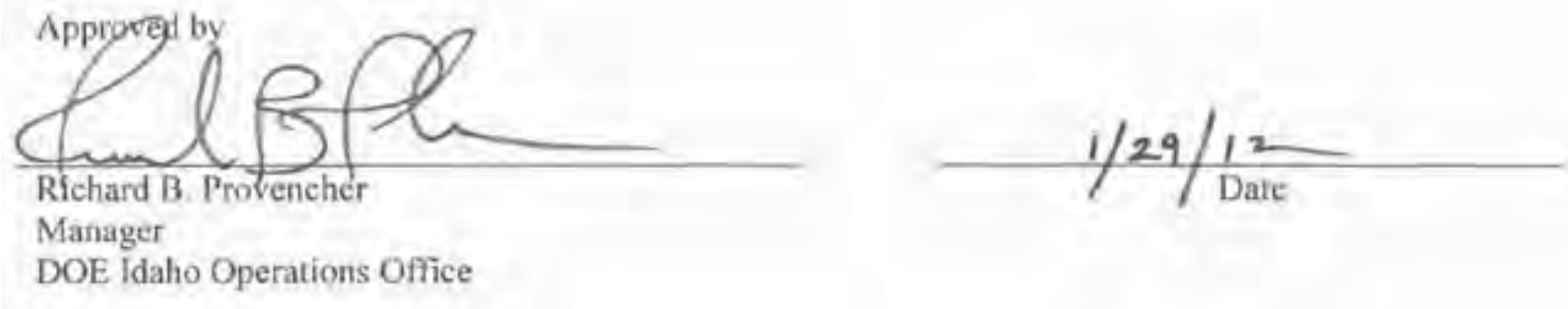
(This Page Intentionally Left Blank) 


\title{
FY 2012 INL Site Sustainability Plan with the FY 2011 Annual Report
}

\author{
DOE/ID-11383 \\ Revision 3
}

January 2012
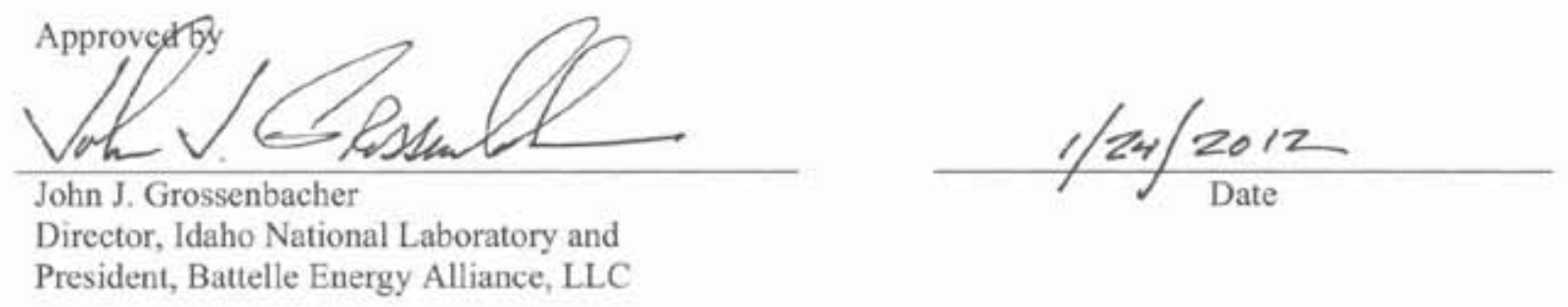
(This Page Intentionally Left Blank) 


\title{
FY 2012 INL Site Sustainability Plan with the FY 2011 Annual Report
}

\author{
DOE/ID-11383 \\ Revision 3
}

January 2012
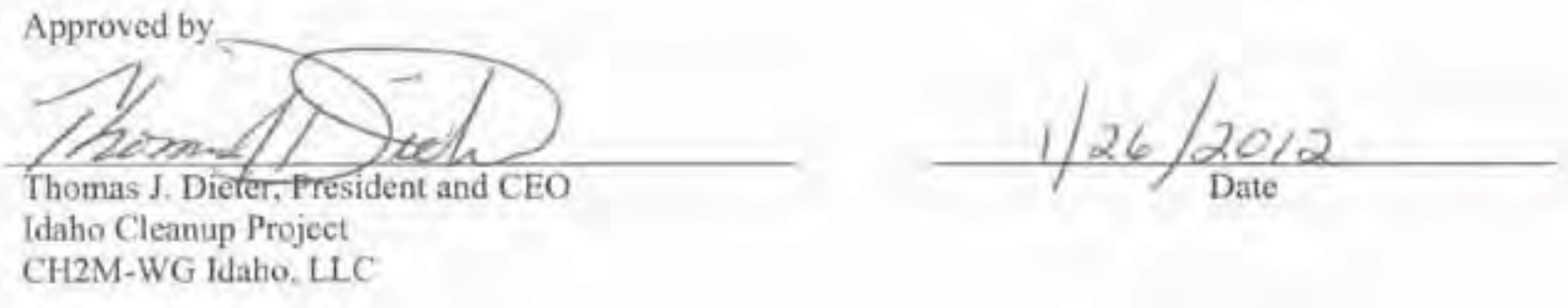

daho Cleanup Project 
(This Page Intentionally Left Blank) 


\title{
FY 2012 INL Site Sustainability Plan with the FY 2011 Annual Report
}

\author{
DOE/ID-11383 \\ Revision 3
}

January 2012
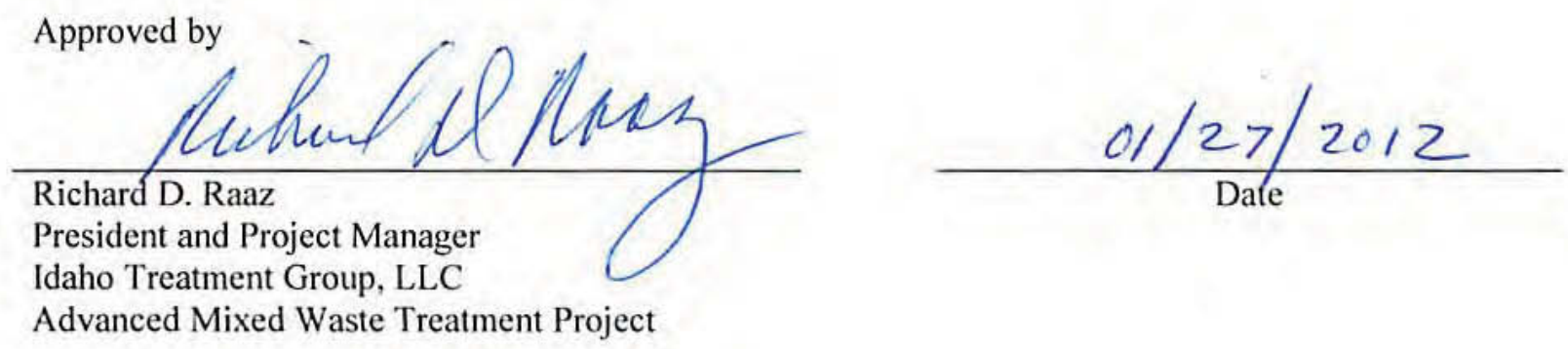
(This Page Intentionally Left Blank) 


\section{EXECUTIVE SUMMARY}

Clean energy and sustainability have long been at the core of the mission of the U.S. Department of Energy (DOE) and are reinforced in Executive Order (EO) 13514, Federal Leadership in Environmental, Energy, and Economic Performance. DOE has articulated its key strategies and goals in its 2011 Strategic Sustainability Performance Plan (SSPP). The Idaho National Laboratory (INL) Site incorporates these strategies through this plan.

Executive Order 13423, "Strengthening Federal Environmental, Energy, and Transportation Management," establishes requirements to cost effectively meet or exceed the goals and objectives of the Energy Policy Act of 2005 for energy efficiency, use of renewable energy, transportation energy, and water conservation at federal facilities. DOE Order 436.1, "Departmental Sustainability," contains requirements that DOE will accomplish to implement EO 13514 and EO 13423.

DOE Order 436.1 provides requirements and assigns responsibilities for managing sustainability within DOE to ensure that missions are carried out in a sustainable manner, to institute wholesale cultural change to factor sustainability and greenhouse gas (GHG) reductions into all DOE decisions, and to ensure that DOE achieves the sustainability goals established in its SSPP. DOE Order 436.1 and the SSPP require that DOE Sites commit appropriate personnel resources, establish a financing plan that prioritizes the use of life-cycle cost effective private sector financing and optimizes the application of appropriations and budgeted funds, and establish specific performance measures and deliverables designed to achieve the listed requirements.

The "FY 2012 INL Site Sustainability Plan with the FY 2011 Annual Report," hereafter referred to as the Plan, was developed according to the narrative requirements from the "Guidance for the FY 2012 DOE Site Sustainability Plans" issued on September 8, 2011. This Plan contains strategies and activities that will lead to continual GHG, energy, water, and transportation fuels efficiency to move the INL Site towards meeting the goals and requirements of the SSPP, EOs 13514 and 13423, and DOE Order 436.1 before the end of Fiscal Year (FY) 2020. The Plan summarizes energy and fuel use reporting requirements and references criteria for performing sustainable design. Plan requirements are integrated into each of the INL Site contractor's Integrated Safety Management System (ISMS) and Environmental Management System (EMS). Finally, Sustainability Program directives based on this Plan are integrated into the Ten-Year Site Plan (TYSP) and operations and acquisition systems.

For the purposes of this document, the "INL Site" is considered all operating contractors and the Department of Energy Idaho Operations Office (DOE-ID), and includes the industrial complexes located west of Idaho Falls and the Idaho Falls buildings. INL is considered to be those facilities operated by Battelle Energy Alliance, LLC (BEA). The Advanced Mixed Waste Treatment Project (AMWTP) and Idaho Cleanup Project (ICP) are referred to by their noted acronyms and include all facilities under their individual responsibility.

This DOE-ID INL Site document serves as an overall INL Site Sustainability Plan. It is supplemented by individual contractor plans and strategies as needed. Updates to the Plan are anticipated annually with added specificity as projects are developed and requirements change. This Plan encompasses all contractors and activities at the INL Site under the control of DOE-ID. The operations and activities of the Naval Reactors Facility (NRF), located on the INL Site, are specifically excluded from this Plan.

The Environmental Management Mission assumptions for this Plan include the AMWTP ceasing operations and be in a cold, dark, and dry status by FY 2018; the remaining ICP operations at the Radioactive Waste Management Complex (RWMC) will be complete by FY 2018 with buildings in a cold, dark and dry status; the Idaho Nuclear Technology Center (INTEC) liquid waste management system operations will be discontinued by FY 2015; and the INTEC New Waste Calcine Facility will be demolished by FY 2015. 
The intent of this Plan is to provide the overall Sustainability strategy for the INL Site during FY 2012. Integral to this Plan is the FY 2011 Annual Report. The Annual Report data for FY 2011 are provided on the Consolidated Energy Data Report (CEDR) that is included as Appendix C.

DOE-ID and the INL Site contractors use their existing EMS to establish goals, track, and review progress towards meeting the energy and water efficiency, greenhouse gas reduction, and renewable energy goals. INL Site contractors will leverage all available sources of funding including Strategic Investment Funding (SIF) and alternative funding programs such as Energy Savings Performance Contracts (ESPC) to implement energy and water reduction projects. Projects identified to date are included on the Conservation Measures worksheet of the CEDR. The INL Site will leverage utility incentive programs to the maximum extent available.

The INL Site spent nearly \$14.9M in FY 2011 for facility, process, and equipment energy. Of this total, $\$ 12.9 \mathrm{M}$ was spent for building energy, $\$ 1.1 \mathrm{M}$ was spent for process energy, and $\$ 878 \mathrm{~K}$ was spent on equipment fuel. The managed area used over 907 billion Btu of energy and 898.0 million gallons of water. Transportation fuel use across the INL Site in FY 2011 totaled 1,157,999 gallons of various types of fuels. The fleet is composed of light-duty vehicles fueled by gasoline and E-85. Heavy-duty vehicles include over-the-road buses fueled by diesel and biodiesel, and a complex assortment of trucks and equipment. Typically, 9.5 million miles are driven annually and over 50,000 hours are logged on heavy equipment.

Table ES-1 and the graph in Figure ES-1 summarize the Annual Report data and provide an FY 2011 status of the DOE SSPP goals. The FY 2011 goals in the graph are the trend point of where the INL Site should be after FY 2011 to remain on track to meet the overall goals by the end of FY 2020. Discussion of the FY 2011 status and planned FY 2012 actions are found in the body of this Plan.

Table ES-1. Annual report data.

\begin{tabular}{|c|c|c|c|c|}
\hline $\begin{array}{c}\text { SSPP } \\
\text { Goal }\end{array}$ & DOE Goal & Performance Status & Planned Actions and Key Issues & $\begin{array}{c}\text { Risk of } \\
\text { Non- } \\
\text { Attainment }\end{array}$ \\
\hline 1.1 & $\begin{array}{l}28 \% \text { Scope } 1 \text { and } \\
2 \text { GHG reduction } \\
\text { by FY } 2020 \text { from } \\
\text { a FY } 2008 \\
\text { baseline }\end{array}$ & $\begin{array}{l}\text { The INL Site Scope } 1 \\
\text { GHG emissions are down } \\
24.8 \% \text { and Scope } 2 \text { GHG } \\
\text { emissions are down } 9.5 \% \text {. } \\
\text { The combined Scope } 1 \text { and } \\
\text { Scope } 2 \text { emissions } \\
\text { decreased } 22.5 \% \text { in FY } \\
2011 \text { as reported by the } \\
\text { Sustainability Performance } \\
\text { Office (SPO). }\end{array}$ & $\begin{array}{l}\text { GHG emission reductions will } \\
\text { primarily be obtained through } \\
\text { efforts to reduce building and } \\
\text { transportation energy. AMWTP and } \\
\text { ICP contract completion will } \\
\text { contribute to further reductions, } \\
\text { helping make progress toward the } \\
\text { goal. } \\
\text { However, an } 8 \% \text { gap in electrical } \\
\text { intensity reduction exists in current } \\
\text { planning. This results in a } 9 \% \text { gap } \\
\text { in meeting the Scope } 1 \text { \& } 2 \text { GHG } \\
\text { reduction goal. A } \$ 42-\$ 52 \mathrm{M} \\
\text { investment in energy efficiency } \\
\text { projects is needed to close the } 9 \% \\
\text { gap. }\end{array}$ & Medium \\
\hline
\end{tabular}


Table ES-1. (continued).

\begin{tabular}{|c|c|c|c|c|}
\hline $\begin{array}{l}\text { SSPP } \\
\text { Goal }\end{array}$ & DOE Goal & Performance Status & Planned Actions and Key Issues & $\begin{array}{c}\text { Risk of } \\
\text { Non- } \\
\text { Attainment }\end{array}$ \\
\hline 1.2 & $\begin{array}{l}30 \% \text { energy } \\
\text { intensity } \\
\text { reduction by } \\
\text { FY } 2015 \text { from a } \\
\text { FY } 2003 \\
\text { baseline }\end{array}$ & $\begin{array}{l}\text { The INL Site has reduced } \\
\text { energy intensity } 5.6 \% \text { from } \\
\text { the FY } 2003 \text { baseline } \\
\text { intensity ( } 10.5 \% \text { when } \\
\text { normalized for weather } \\
\text { factors) as demonstrated } \\
\text { through data entered into } \\
\text { the CEDR and compared to } \\
\text { FY } 2003 \text { data. }\end{array}$ & $\begin{array}{l}\text { The INL Site short range energy } \\
\text { reduction strategies account for a } \\
22 \% \text { reduction in energy intensity } \\
\text { by FY } 2015 \text {. An } 8 \% \text { gap in } \\
\text { electrical intensity reduction exists. } \\
\text { To achieve the initial } 22 \% \\
\text { reduction, capital project upgrades } \\
\text { are planned primarily through } \\
\text { alternative funding mechanisms that } \\
\text { include ESPC and UESC. } \\
\text { Additionally, INL Strategic } \\
\text { Investment funded projects are } \\
\text { planned for FY } 2012 \text { through } \\
\text { FY } 2015 \text { that will assist with } \\
\text { additional energy savings. Finally, } \\
\text { AMWTP and ICP contract } \\
\text { completion will contribute to further } \\
\text { reductions, helping make progress } \\
\text { toward the goal. Closing the } 8 \% \\
\text { energy reduction gap will require } \\
\text { approximately } \$ 42-\$ 52 \mathrm{M} \text { in energy } \\
\text { efficiency projects. }\end{array}$ & Medium \\
\hline 1.3 & $\begin{array}{l}\text { Individual } \\
\text { building or } \\
\text { processes } \\
\text { metering for } \\
90 \% \text { of } \\
\text { electricity (by } \\
\text { October 1, } \\
2012 \text { ); for } 90 \% \\
\text { of steam, natural } \\
\text { gas, and chilled } \\
\text { water (by } \\
\text { October } 1, \\
2015) \text {. }\end{array}$ & $\begin{array}{l}\text { The INL Site meters } 100 \% \\
\text { of its natural gas and } 53 \% \\
\text { of its electric usage. An } \\
\text { analysis was performed on } \\
\text { all existing infrastructure } \\
\text { that will still be in place by } \\
\text { FY } 2020 \text {. From this } \\
\text { analysis, the INL FY } 2011 \\
\text { Metering Plan (PLN-3911) } \\
\text { was developed to provide a } \\
\text { roadmap on how the INL } \\
\text { Site will reach the goal of } \\
\text { metering } 90 \% \text { of } \\
\text { electricity. } \\
\text { Metering was installed in } \\
\text { FY } 2011 \text { on seven facilities } \\
\text { with the highest probability } \\
\text { of meeting the Guiding } \\
\text { Principles (GPs). }\end{array}$ & $\begin{array}{l}\text { Meters will be installed over the } \\
\text { next } 2 \text { years to be compliant with } \\
\text { the } 90 \% \text { metering goal. At no cost } \\
\text { to DOE, the City of Idaho Falls is } \\
\text { planning to upgrade all of its } \\
\text { electrical power meters to smart } \\
\text { meter technology and INL's Idaho } \\
\text { Falls facilities will be upgraded as } \\
\text { part of the city's initial upgrade } \\
\text { project during FY } 2012 \text {. The } \\
\text { remainder of the } 23 \text { facilities } \\
\text { identified as having the highest } \\
\text { probability of meeting the GPs are } \\
\text { targeted for meter installations in } \\
\text { FY } 2012 \text {. } \\
\text { All other meters are planned for } \\
\text { installation through ESPC projects. }\end{array}$ & $\begin{array}{l}\text { Low } \\
\text { The INL Site } \\
\text { did not meet } \\
\text { the } \\
\text { October } 01 \text {, } \\
2012 \text { deadline, } \\
\text { but will meet } \\
\text { the } 90 \% \text { goal } \\
\text { within } 2 \text { years. }\end{array}$ \\
\hline
\end{tabular}


Table ES-1. (continued).

\begin{tabular}{|c|c|c|c|c|}
\hline $\begin{array}{l}\text { SSPP } \\
\text { Goal }\end{array}$ & DOE Goal & Performance Status & Planned Actions and Key Issues & $\begin{array}{c}\text { Risk of } \\
\text { Non- } \\
\text { Attainment }\end{array}$ \\
\hline 1.4 & $\begin{array}{l}\text { Cool roofs, } \\
\text { unless } \\
\text { uneconomical, } \\
\text { for roof } \\
\text { replacements } \\
\text { unless project } \\
\text { already has } \\
\text { CD-2 approval. } \\
\text { New roofs must } \\
\text { have thermal } \\
\text { resistance of at } \\
\text { least R-30. }\end{array}$ & $\begin{array}{l}\text { The INL Site replaced } \\
19,933 \mathrm{ft}^{2} \text { of roofing on } \\
\text { two existing buildings with } \\
\text { cool roofs using the RAMP } \\
\text { program. Two additional } \\
\text { cool roofs were installed } \\
\text { using INL's normal roof } \\
\text { replacement program. }\end{array}$ & $\begin{array}{l}\text { AMWTP and ICP project } \\
\text { completion do not involve } \\
\text { installation of cool roofs. However, } \\
\text { INL roof replacements planned for } \\
\text { FY } 2012 \text { will result in new cool } \\
\text { roofs exceeding } 20,000 \mathrm{ft}^{2} \text {. } \\
\text { Additionally, the new Energy } \\
\text { Systems Laboratory (ESL) will be } \\
\text { complete in FY } 2012 \text { and will } \\
\text { include a cool roof. }\end{array}$ & $\begin{array}{l}\text { Low } \\
\text { Unless funding } \\
\text { for RAMP is } \\
\text { eliminated. }\end{array}$ \\
\hline 1.5 & $\begin{array}{l}7.5 \% \text { of annual } \\
\text { electricity } \\
\text { consumption } \\
\text { from renewable } \\
\text { sources by } \\
\text { FY } 2013 \text { and } \\
\text { thereafter ( } 5 \% \\
\text { FY 2010-FY } \\
\text { 2012). }\end{array}$ & $\begin{array}{l}\text { The INL Site produced no } \\
\text { onsite renewable energy, } \\
\text { but procured a total of } \\
16,900 \text { MWh of } \\
\text { Renewable Energy } \\
\text { Certificates (RECs) from } \\
\text { the Western Area Power } \\
\text { Administration (WAPA). } \\
\text { This purchase represents } \\
7.5 \% \text { of the INL Site } \\
\text { electric usage. }\end{array}$ & $\begin{array}{l}\text { AMWTP and ICP project } \\
\text { completion do not involve } \\
\text { installation of renewable energy } \\
\text { systems. However, INL is actively } \\
\text { pursuing Renewable Energy } \\
\text { Generation capability and annually } \\
\text { purchases RECs in amounts as } \\
\text { outlined in the Energy Policy Act of } \\
\text { 2005. } \\
\text { Non-Attainment Issue: } \\
\text { Although technically feasible, low } \\
\text { electric costs and long paybacks } \\
\text { make renewable energy installation } \\
\text { economically challenging. } \\
\text { Leveraging potential ESPC } \\
\text { renewable energy installation (solar, } \\
\text { geothermal, wind, bio-mass) may } \\
\text { provide up to a maximum of } 2 \% \\
\text { onsite renewable energy generation. } \\
\text { The remaining } 5.5 \% \text { gap will } \\
\text { require major investments and long- } \\
\text { term purchase agreements (up to } 40 \\
\text { years). A privately operated wind } \\
\text { farm installed on INL property } \\
\text { would require } \$ 15 \mathrm{M} \text { in supporting } \\
\text { infrastructure for the project to be } \\
\text { commercially viable. Onsite solar } \\
\text { installation would require over } \\
\$ 35 \mathrm{M} \text {, plus the cost of maintaining } \\
\text { an owned solar generating facility. }\end{array}$ & $\begin{array}{l}\text { High } \\
\text { See Non- } \\
\text { Attainment } \\
\text { Issue statement }\end{array}$ \\
\hline
\end{tabular}


Table ES-1. (continued).

\begin{tabular}{|c|c|c|c|c|}
\hline $\begin{array}{l}\text { SSPP } \\
\text { Goal }\end{array}$ & DOE Goal & Performance Status & Planned Actions and Key Issues & $\begin{array}{c}\text { Risk of } \\
\text { Non- } \\
\text { Attainment }\end{array}$ \\
\hline 1.6 & $\begin{array}{l}10 \% \text { annual } \\
\text { increase in fleet } \\
\text { alternative fuel } \\
\text { consumption } \\
\text { through FY } 2015 \\
\text { relative to a } \\
\text { FY } 2005 \\
\text { baseline. }\end{array}$ & $\begin{array}{l}\text { The INL Site has exceeded } \\
\text { the FY } 2015 \text { goal by } \\
\text { increasing alternative fuel } \\
210 \% \text { relative to FY } 2005 \text {. } \\
\text { In FY } 2011 \text { the INL Site } \\
\text { used } 236,889 \text { gasoline } \\
\text { gallon equivalents of } \\
\text { alternative fuels. This } \\
\text { represents an increase of } \\
210 \% \text { over the FY } 2005 \\
\text { use, and a } 39 \% \text { increase } \\
\text { over FY } 2010 \text { use. }\end{array}$ & $\begin{array}{l}\text { The INL Site will continue to } \\
\text { purchase alternative fuel vehicles in } \\
\text { support of this goal. INL will } \\
\text { optimize the fleet through bus and } \\
\text { heavy truck replacements that are } \\
\text { more efficient and operate on } \\
\text { biodiesel. } \\
\text { However, recent DOE-HQ and GSA } \\
\text { direction has placed an emphasis on } \\
\text { hybrid vehicle purchases. Hybrid } \\
\text { vehicles are not flex fuel capable, so } \\
\text { future alternative fuel consumption } \\
\text { may decrease. }\end{array}$ & Low \\
\hline 1.7 & $\begin{array}{l}2 \% \text { annual } \\
\text { reduction in fleet } \\
\text { petroleum } \\
\text { consumption } \\
\text { through FY } 2015 \\
\text { relative to a } \\
\text { FY } 2005 \\
\text { baseline. }\end{array}$ & $\begin{array}{l}\text { In FY 2011, the INL Site } \\
\text { used } 862,527 \text { gasoline } \\
\text { gallons equivalent of } \\
\text { petroleum, an } 8.1 \% \\
\text { reduction from FY } 2005 \text {. }\end{array}$ & $\begin{array}{l}\text { The INL Site will continue to obtain } \\
\text { increasingly fuel-efficient buses, } \\
\text { procure efficient light-duty vehicles, } \\
\text { and research the feasibility of } \\
\text { implementing alternative fuel for } \\
\text { bus operations. AMWTP and ICP } \\
\text { contract completion will contribute } \\
\text { to further reductions, helping } \\
\text { exceed the goal. }\end{array}$ & Medium \\
\hline 1.8 & $\begin{array}{l}75 \% \text { of light- } \\
\text { duty vehicle } \\
\text { purchases must } \\
\text { consist of } \\
\text { alternative fuel } \\
\text { vehicles (AFVs) } \\
\text { by FY } 2015 \text {. }\end{array}$ & $\begin{array}{l}\text { The INL Site acquired } 101 \\
\text { light-duty vehicles in } \\
\text { FY } 2011,47 \text { are flex-fuel } \\
(46.5 \%), 46 \text { are hybrid } \\
(45.5 \%) \text { and } 8 \text { are gasoline } \\
(8 \%) . \text { Of the } 101 \text { acquired, } \\
92 \% \text { are either AFVs or } \\
\text { hybrid vehicles. }\end{array}$ & $\begin{array}{l}\text { The INL Site will continue to } \\
\text { replace the current fleet with AFVs } \\
\text { as General Services Administration } \\
\text { (GSA) allows. } \\
\text { However, hybrid vehicles are not } \\
\text { AFVs and DOE-HQ is mandating } \\
\text { hybrid vehicles be purchased. As } \\
\text { seen in the FY } 2011 \text { status, this } \\
\text { greatly affects the percentage. A } \\
\text { decision is needed on which vehicle } \\
\text { type is more important: AFV or } \\
\text { hybrid. }\end{array}$ & $\begin{array}{l}\text { Medium } \\
\text { Based on } \\
\text { directives and } \\
\text { vehicles } \\
\text { available from } \\
\text { GSA. }\end{array}$ \\
\hline 1.9 & $\begin{array}{l}\text { Reduce fleet } \\
\text { inventory by } \\
35 \% \text { within the } \\
\text { next } 3 \text { years } \\
\text { relative to a } \\
\text { FY } 2005 \\
\text { baseline. }\end{array}$ & $\begin{array}{l}\text { The INL Site reduced } \\
\text { vehicle fleet inventory } \\
15 \% \text { in FY } 2011 \text { and is on } \\
\text { track to meet the } 35 \% \\
\text { reduction by FY } 2015 \text {, } \\
\text { including interim goals. }\end{array}$ & $\begin{array}{l}\text { The INL Site is on track to meet the } \\
35 \% \text { reduction commitment made to } \\
\text { DOE-HQ. INL performed a 2-year } \\
\text { utilization study and has begun } \\
\text { reducing the size of the INL fleet } \\
\text { while ensuring the ability to meet } \\
\text { the INL mission. } \\
\text { Completion of the AMWTP and } \\
\text { ICP contracts will remove dozens of } \\
\text { vehicles from the fleet inventory. }\end{array}$ & Low \\
\hline
\end{tabular}


Table ES-1. (continued).

\begin{tabular}{|c|c|c|c|c|}
\hline $\begin{array}{l}\text { SSPP } \\
\text { Goal }\end{array}$ & DOE Goal & Performance Status & Planned Actions and Key Issues & $\begin{array}{c}\text { Risk of } \\
\text { Non- } \\
\text { Attainment }\end{array}$ \\
\hline 2.1 & $\begin{array}{l}13 \% \text { Scope } 3 \\
\text { GHG Reduction } \\
\text { by FY } 2020 \text { from } \\
\text { a FY } 2008 \\
\text { baseline. }\end{array}$ & $\begin{array}{l}\text { The INL Site reduced } \\
\text { Scope } 3 \text { GHG emissions } \\
23.3 \% \text { in FY } 2011 \\
\text { compared to FY } 2008 \\
\text { according to the data in the } \\
\text { CEDR, exceeding the } 13 \% \\
\text { reduction goal } 9 \text { years } \\
\text { early. }\end{array}$ & $\begin{array}{l}\text { The INL Site will reduce Scope } 3 \\
\text { GHG emissions primarily through } \\
\text { employee commute reduction } \\
\text { tactics and employee travel } \\
\text { reduction tactics. }\end{array}$ & Low \\
\hline 3.1 & $\begin{array}{l}15 \% \text { of existing } \\
\text { buildings greater } \\
\text { than } 5,000 \text { gross } \\
\text { square feet } \\
\text { (GSF) are } \\
\text { compliant with } \\
\text { the GPs of High } \\
\text { Performance } \\
\text { Sustainable } \\
\text { Buildings } \\
\text { (HPSB) by } \\
\text { FY 2015 }\end{array}$ & $\begin{array}{l}\text { The INL Site has } 2 \% \text { of } \\
\text { existing facilities that are } \\
\text { compliant with the GPs. } \\
\text { AMWTP and ICP project } \\
\text { completion do not involve } \\
\text { bringing facilities in } \\
\text { compliance with the GPs. } \\
\text { Although the INL Site } \\
\text { requires only } 26 \text { facilities } \\
\text { to achieve the GPs (15\% of } \\
\text { the entire INL Site), INL } \\
\text { identified } 27 \text { facilities with } \\
\text { the highest probability of } \\
\text { meeting the GPs. These } \\
\text { facilities were entered into } \\
\text { Portfolio Manager, are } \\
\text { planned for meter } \\
\text { installations, and are } \\
\text { included in plans for } \\
\text { energy and efficiency } \\
\text { upgrades. } \\
\text { Of these } 27 \text { facilities, two } \\
\text { are currently Leadership in } \\
\text { Energy and Environmental } \\
\text { Design (LEED } \\
\text { certified, four are in } \\
\text { construction and are } \\
\text { awaiting LEED } \\
\text { certification, and the } \\
\text { balance are being worked } \\
\text { for Guiding Principle } \\
\text { implementation. }\end{array}$ & $\begin{array}{l}\text { All enduring infrastructure at } \\
\text { Central Facilities Area and the } \\
\text { Advanced Test Reactor Complex } \\
\text { (ATR), and low security facilities at } \\
\text { the Specific Manufacturing } \\
\text { Complex (SMC) were evaluated as } \\
\text { part of developing INL ESPC } \\
\text { Project } 3 \text {. The five GPs are planned } \\
\text { for implementation through the } \\
\text { ESPC, although not at EM facilities. } \\
\text { In FY } 2012 \text {, INL will implement } \\
\text { projects in Idaho Falls (IF) Facilities } \\
\text { including IF-616 (WCB), IF-654 } \\
\text { (EROB), and IF-601 (ROB) that } \\
\text { will help these buildings to obtain a } \\
\text { passing Energy Star rating score and } \\
\text { will be further evaluated using } \\
\text { Portfolio Manager. } \\
\text { INL is planning to certify IF-663 } \\
\text { (RSF) and IF-654 (EROB) in } \\
\text { FY } 2012 \text { as meeting the GPs using } \\
\text { Portfolio Manager, an increase of } \\
1 \% \text {. } \\
\text { Non- Attainment Issue: } \\
\text { The INL Site is responsible for } \\
\text { obtaining Guiding Principle } \\
\text { certification on } 15 \% \text { of the INL Site } \\
\text { Buildings ( } 26 \text { total based on current } \\
\text { enduring infrastructure numbers). } \\
\text { AMWTP and ICP will not } \\
\text { contribute to this goal due to DOE- } \\
\text { HQ direction that EM facilities at } \\
\text { the site will not be a part of the } \\
\text { ESPCs. INL had planned on } \\
\text { obtaining GP certification on } \\
16 \text { buildings, which equates to } 15 \% \\
\text { of the INL controlled buildings. } \\
\text { Although a new plan is in place to } \\
\text { achieve GP compliance on all } 26,\end{array}$ & $\begin{array}{l}\text { High } \\
\text { See Non- } \\
\text { Attainment } \\
\text { Issue statement }\end{array}$ \\
\hline
\end{tabular}


Table ES-1. (continued).

\begin{tabular}{|c|c|c|c|c|}
\hline $\begin{array}{l}\text { SSPP } \\
\text { Goal }\end{array}$ & DOE Goal & Performance Status & Planned Actions and Key Issues & $\begin{array}{c}\text { Risk of } \\
\text { Non- } \\
\text { Attainment }\end{array}$ \\
\hline & & & $\begin{array}{l}\text { the remaining } 10 \text { facilities were } \\
\text { added in FY } 2012 \text { to the INL total } \\
\text { and may not reach GP } \\
\text { implementation until after FY } 2015 \text {. } \\
\text { Energy efficiency project funding, } \\
\text { meter installation, and operating } \\
\text { considerations may cause the new } \\
\text { planned GP implementation date to } \\
\text { slip } 1 \text { or } 2 \text { years for the additional } \\
10 \text { buildings. }\end{array}$ & \\
\hline 3.2 & $\begin{array}{l}\text { All new } \\
\text { construction, } \\
\text { major } \\
\text { renovations, and } \\
\text { alternations of } \\
\text { buildings greater } \\
\text { than } 5,000 \text { GSF } \\
\text { must comply } \\
\text { with the GPs and } \\
\text { where the work } \\
\text { exceeds } \$ 5 \mathrm{M} \text {, } \\
\text { each are } \\
\text { LEED }{ }^{\mathrm{TM}} \mathrm{NC} \\
\text { Gold } \\
\text { certification or } \\
\text { equivalent }\end{array}$ & $\begin{array}{l}\text { The INL Site ensures all } \\
\text { new construction, major } \\
\text { renovations, and } \\
\text { alternations of buildings } \\
\text { greater than } 5,000 \mathrm{GSF} \\
\text { comply with the GPs and } \\
\text { where the work exceeds } \\
\$ 5 \mathrm{M} \text {, are LEED }{ }^{\mathrm{TM}} \mathrm{NC} \\
\text { Gold certified or } \\
\text { equivalent. The INL } \\
\text { Technical Support } \\
\text { Building (TSB) at the ATR } \\
\text { Complex received } \\
\text { LEED }{ }^{\mathrm{TM}} \text { certification on } \\
\text { March } 31,2011 \text {. }\end{array}$ & $\begin{array}{l}\text { AMWTP and ICP project } \\
\text { completion do not involve } \\
\text { certification of temporary facilities. } \\
\text { However, INL continues to pursue } \\
\text { certification at enduring facilities. } \\
\text { IF-683, Radiological Environmental } \\
\text { Sciences Laboratory (RESL) will be } \\
\text { certified at LEED } \\
2012 \text { and IF- } 685 \text { (ESL) is under } \\
\text { construction and is expected to be } \\
\text { submitted for LEED }{ }^{\mathrm{TM}} \text { Gold in FY } \\
\text { 2013. The INL Site Ten Year Site } \\
\text { Plan (TYSP) has institutionalized } \\
\text { sustainability as a core driver during } \\
\text { campus and building planning. }\end{array}$ & Low \\
\hline
\end{tabular}


Table ES-1. (continued).

\begin{tabular}{|c|c|c|c|c|}
\hline $\begin{array}{l}\text { SSPP } \\
\text { Goal }\end{array}$ & DOE Goal & Performance Status & Planned Actions and Key Issues & $\begin{array}{c}\text { Risk of } \\
\text { Non- } \\
\text { Attainment }\end{array}$ \\
\hline 4.1 & $\begin{array}{l}26 \% \text { water } \\
\text { intensity } \\
\text { reduction by FY } \\
2020 \text { from a FY } \\
2007 \text { baseline. }\end{array}$ & $\begin{array}{l}\text { The INL Site has reduced } \\
\text { water use intensity by } 4 \% \\
\text { and total water pumped by } \\
14.5 \% \text { as compared to the } \\
\text { FY } 2007 \text { baseline. } \\
\text { A water assessment was } \\
\text { performed by a water } \\
\text { assessment team from } \\
\text { Pacific Northwest National } \\
\text { Laboratory (PNNL) was } \\
\text { initiated at ATR Complex } \\
\text { to identify reduction } \\
\text { opportunities. }\end{array}$ & $\begin{array}{l}\text { The INL Site will continue to } \\
\text { develop and install projects that } \\
\text { conserve water, primarily through } \\
\text { ESPC project development at the } \\
\text { ATR Complex and Central } \\
\text { Facilities Area and leveraging } \\
\text { assessments done by PNNL. } \\
\text { AMWTP and ICP contract } \\
\text { completion will contribute to further } \\
\text { reductions, (AMWTP completion - } \\
7.1 \text { M gal. annually; Liquid Waste } \\
\text { Management System-56 M gal. } \\
\text { annually). D } \\
\text { Non-Attainment Issue: } \\
\text { Due to low cost water and } \\
\text { electricity, payback on water } \\
\text { efficiency projects can be as much } \\
\text { as } 200 \text { years, unreasonable to } \\
\text { taxpayers and detrimental to INL } \\
\text { missions. The INL Site is unlikely } \\
\text { to achieve this goal. Retrofits on } \\
\text { existing industrial process, } \\
\text { primarily at the ATR Complex, are } \\
\text { estimated at over } \$ 75 \mathrm{M} \text {. The INL } \\
\text { Site estimates a water intensity } \\
\text { reduction of } 10 \%-12 \% \text { by FY } 2020 \text {. }\end{array}$ & $\begin{array}{l}\text { High } \\
\text { See Non- } \\
\text { Attainment } \\
\text { Issue statement }\end{array}$ \\
\hline 4.2 & $\begin{array}{l}20 \% \text { water } \\
\text { consumption } \\
\text { reduction of } \\
\text { industrial, } \\
\text { landscaping, and } \\
\text { agricultural } \\
\text { (ILA) water by } \\
\text { FY } 2020 \text { from a } \\
\text { FY } 2010 \\
\text { baseline. }\end{array}$ & $\begin{array}{l}\text { ILA water is not applicable } \\
\text { to the INL Site. All water } \\
\text { obtained by the INL Site is } \\
\text { obtained from the Snake } \\
\text { River Plain Aquifer and is } \\
\text { potable. The INL Site does } \\
\text { not have access to any non- } \\
\text { potable water supplies. }\end{array}$ & NA. & Low \\
\hline 5.1 & $\begin{array}{l}\text { Divert at least } \\
50 \% \text { of non- } \\
\text { hazardous solid } \\
\text { waste, excluding } \\
\text { construction and } \\
\text { demolition } \\
\text { debris, by FY } \\
2015 \text {. }\end{array}$ & $\begin{array}{l}\text { The INL Site diverted } \\
15.3 \% \text { of its non-hazardous } \\
\text { solid waste in FY } 2011 \text {. } \\
\text { INL diverted } 24.6 \% \text { of } \\
\text { municipal solid waste from } \\
\text { the landfill in FY } 2011 \text {. }\end{array}$ & $\begin{array}{l}\text { The INL Site will continue to } \\
\text { evaluate potential outlets and the } \\
\text { expansion of recyclable waste } \\
\text { streams and to further increase the } \\
\text { amount of wastes diverted from the } \\
\text { landfill. }\end{array}$ & Medium \\
\hline
\end{tabular}


Table ES-1. (continued).

\begin{tabular}{|c|c|c|c|c|}
\hline $\begin{array}{l}\text { SSPP } \\
\text { Goal }\end{array}$ & DOE Goal & Performance Status & Planned Actions and Key Issues & $\begin{array}{l}\text { Risk of } \\
\text { Non- } \\
\text { Attainment }\end{array}$ \\
\hline 5.2 & $\begin{array}{l}\text { Divert at least } \\
50 \% \text { of } \\
\text { construction and } \\
\text { demolition } \\
\text { materials and } \\
\text { debris by FY } \\
2015 \text {. }\end{array}$ & $\begin{array}{l}\text { The INL Site diverted } 12 \% \\
\text { of its construction and } \\
\text { demolition (C\&D) } \\
\text { materials in FY } 2011 . \text { The } \\
\text { majority of AMWTP and } \\
\text { ICP C\&D waste is } \\
\text { prohibited from offsite } \\
\text { reuse due to the DOE } \\
\text { moratorium. } \\
\text { INL diverted } 39.4 \% \text { of the } \\
\text { construction and } \\
\text { demolition waste during } \\
\text { FY } 2011 \text {. }\end{array}$ & $\begin{array}{l}\text { The INL Site will work to } \\
\text { incorporate additional materials into } \\
\text { current C\&D waste diversion } \\
\text { process and will take actions to } \\
\text { accurately measure wood waste } \\
\text { diverted to the wood chipper. }\end{array}$ & Medium \\
\hline 6.1 & $\begin{array}{l}\text { Procurements } \\
\text { meet } \\
\text { sustainability } \\
\text { requirements and } \\
\text { include } \\
\text { sustainable } \\
\text { acquisition } \\
\text { clause (95\% } \\
\text { each year). }\end{array}$ & $\begin{array}{l}\text { AMWTP and ICP do not } \\
\text { track this data. INL } \\
\text { implemented a new } \\
\text { automated tracking process } \\
\text { in FY } 2011 \text { and } \\
\text { preliminary numbers show } \\
\text { that } 31 \% \text { of the contracts } \\
\text { contained the sustainable } \\
\text { acquisition clause. }\end{array}$ & $\begin{array}{l}\text { INL is incorporating numerous } \\
\text { changes to improve the Sustainable } \\
\text { Acquisition Program including } \\
\text { procedures, policies, and enhanced } \\
\text { work processes that increase the } \\
\text { visibility, availability, and use of } \\
\text { sustainable products }\end{array}$ & Medium \\
\hline 7.1 & $\begin{array}{l}\text { All data centers } \\
\text { are metered to } \\
\text { measure a } \\
\text { monthly PUE } \\
(100 \% \text { by FY } \\
2015) \text {. }\end{array}$ & $\begin{array}{l}\text { The INL Site meters one of } \\
\text { two Data Centers and is } \\
\text { connected to the building } \\
\text { control system. }\end{array}$ & $\begin{array}{l}\text { The INL Site plans to implement } \\
\text { metering for the second and last } \\
\text { data center at the Information and } \\
\text { Operations Research Center. }\end{array}$ & Low \\
\hline 7.2 & $\begin{array}{l}\text { Maximum } \\
\text { annual weighted } \\
\text { average Power } \\
\text { Utilization } \\
\text { Effectiveness } \\
\text { (PUE) of } 1.4 \text { by } \\
\text { FY 2015. }\end{array}$ & $\begin{array}{l}\text { The INL High } \\
\text { Performance Computing } \\
\text { (HPC) data center PUE is } \\
1.3-1.4 \text {. }\end{array}$ & $\begin{array}{l}\text { The PUE for the second data center } \\
\text { will be calculated when full } \\
\text { metering is implemented. }\end{array}$ & Low \\
\hline 7.3 & $\begin{array}{l}\text { Electronic } \\
\text { Stewardship - } \\
100 \% \text { of eligible } \\
\text { PCs, laptops, and } \\
\text { monitors with } \\
\text { power } \\
\text { management } \\
\text { activity } \\
\text { implemented and } \\
\text { in use by FY } \\
2012 .\end{array}$ & $\begin{array}{l}\text { INL and ICP both won the } \\
\text { FEC Bronze award in FY } \\
2011 . \text { Power management } \\
\text { controls are in place on the } \\
\text { majority of eligible } \\
\text { computer systems. At INL, } \\
100 \% \text { of eligible PCs have } \\
\text { power management } \\
\text { controls. }\end{array}$ & $\begin{array}{l}\text { Numerous actions are planned for } \\
\text { FY } 2012 \text { that will continue to } \\
\text { support the Federal Electronics } \\
\text { Challenge and work towards } \\
\text { achieving the FY } 2012 \text { Power } \\
\text { Management Goal. }\end{array}$ & Medium \\
\hline
\end{tabular}




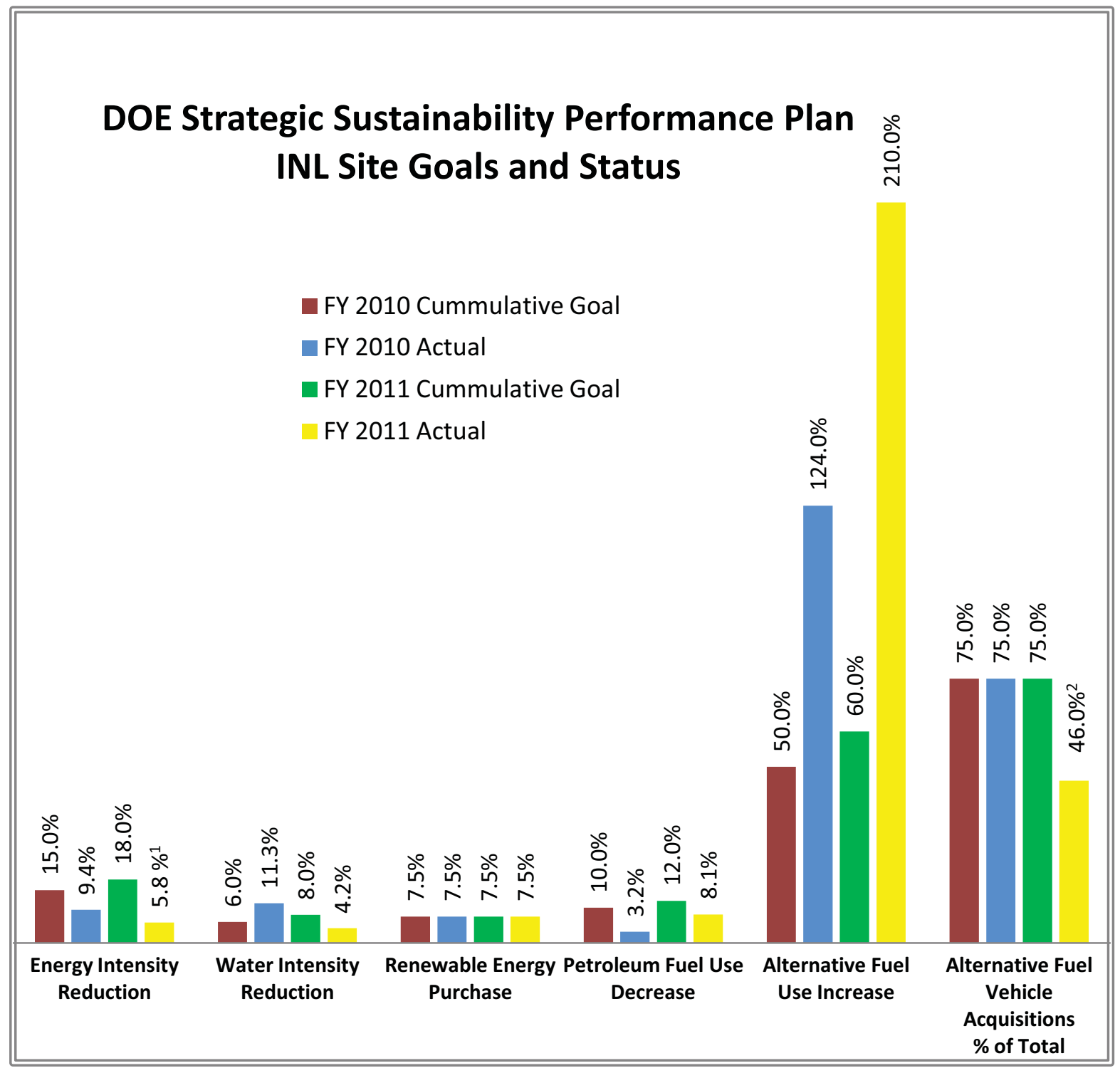

Figure ES-1. Current INL Site status to the DOE goals.

Figure ES-1 shows the INL Site cumulative goal and status for FY 2010 and FY 2011. The cumulative goals are based on individual baseline years as required in Executive Orders.

1. Energy intensity normalized for weather would be $-10.5 \%$.

2. Alternative fuel vehicle purchases are down significantly due to the DOE requirements to procure hybrid light duty vehicles when available. The INL Site acquired 101 light-duty vehicles in FY 2011, 47 are flex-fuel (46.5\%), 46 are hybrid (45.5\%), and 8 are gasoline (8\%). Of the 101 acquired, $92 \%$ are either AFVs or hybrid vehicles. 


\section{CONTENTS}

EXECUTIVE SUMMARY ........................................................................................................

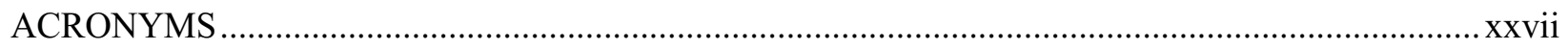



1.1 Scopes 1 and 2 Greenhouse Gas Reduction ............................................................. 1

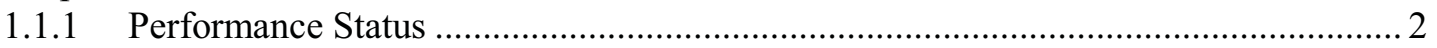

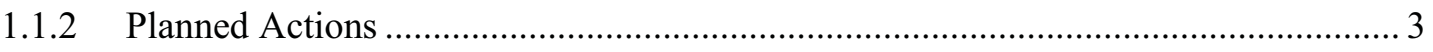

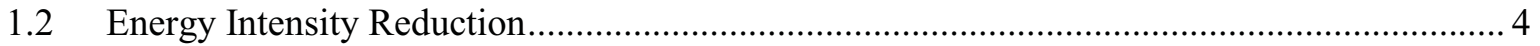

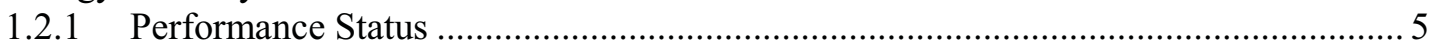

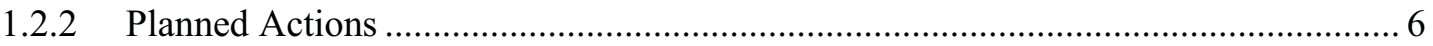

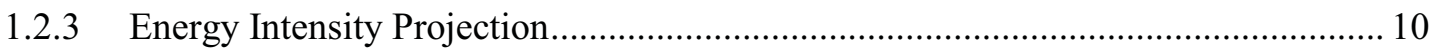

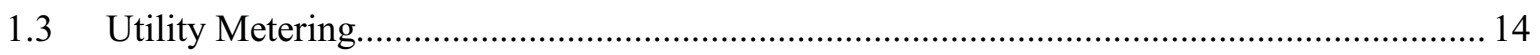

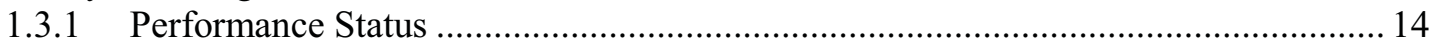

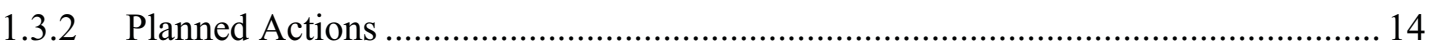

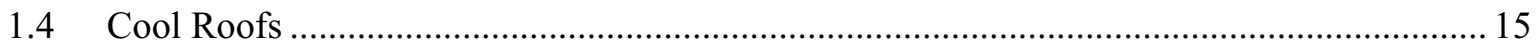

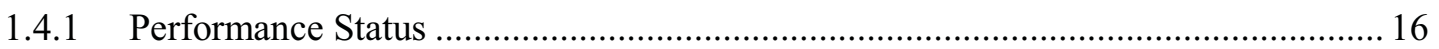

1.4.2 Planned Actions .......................................................................................... 16

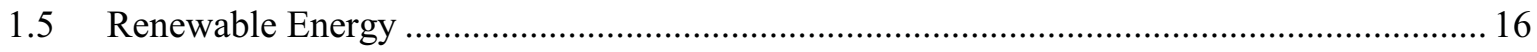

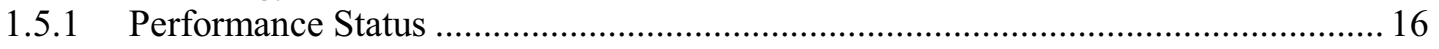

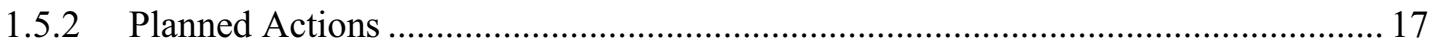

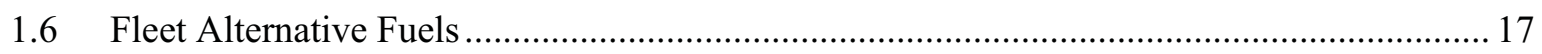

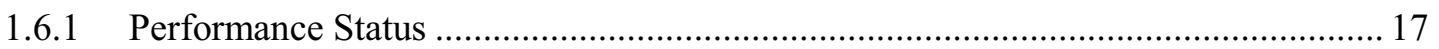

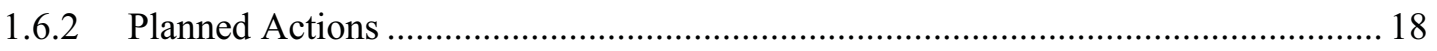

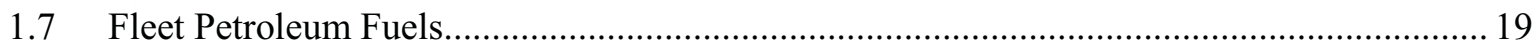

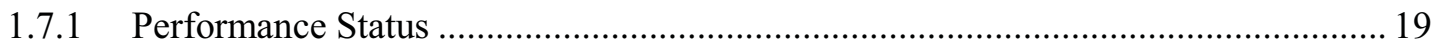

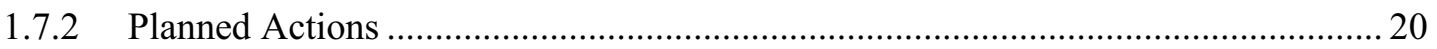

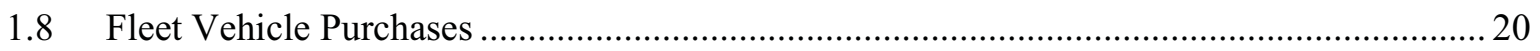



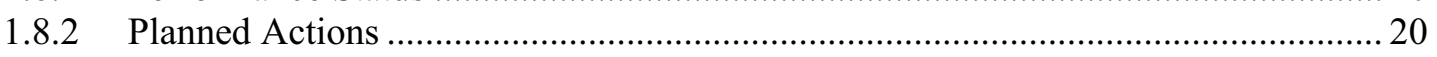

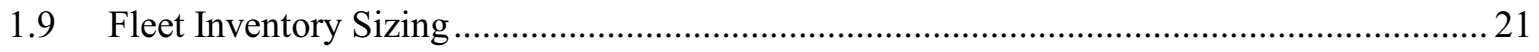

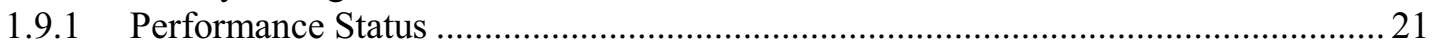

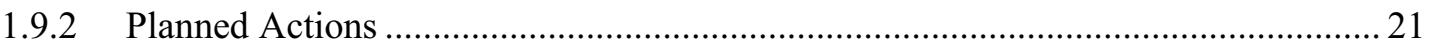

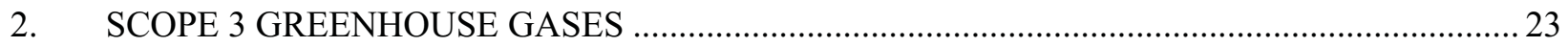

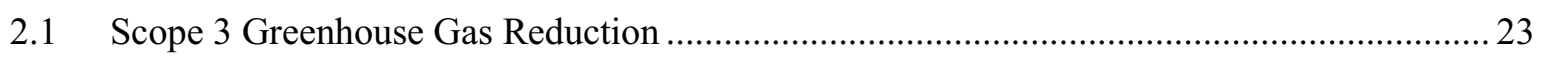

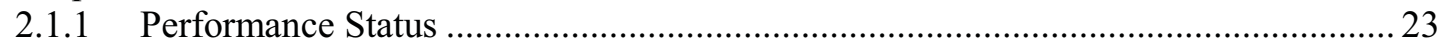

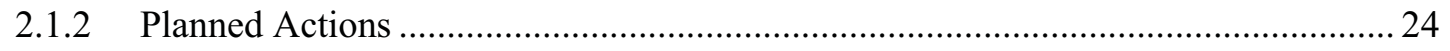

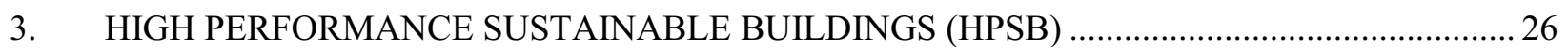

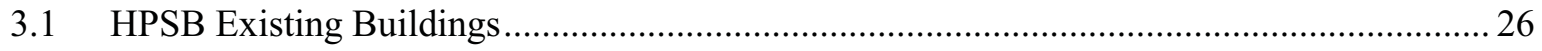

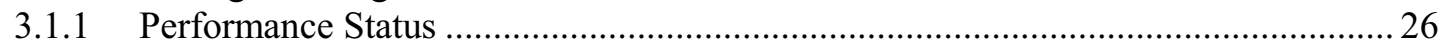

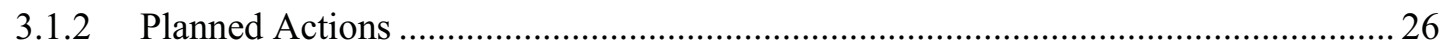

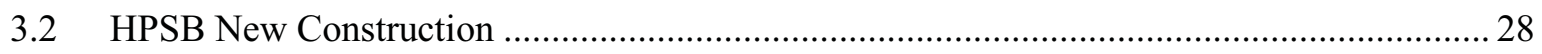

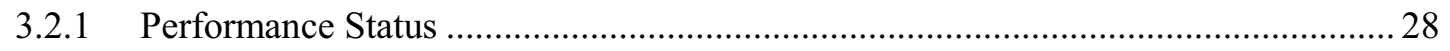

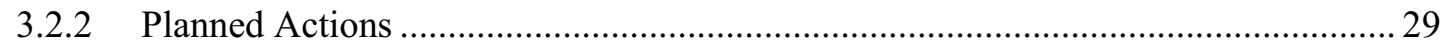




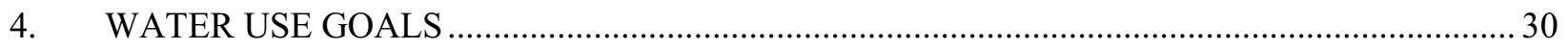

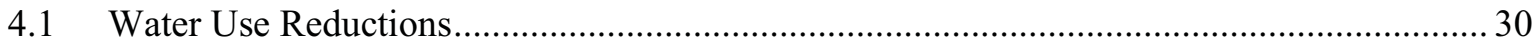

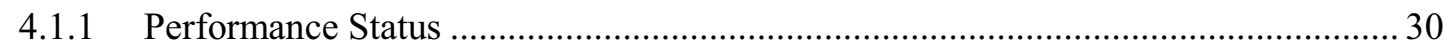



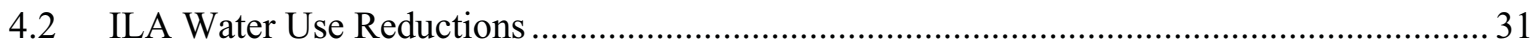

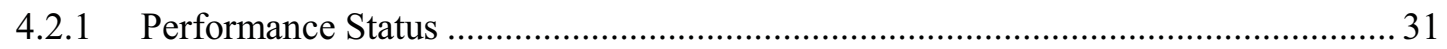

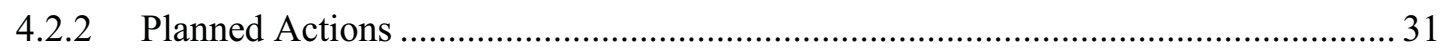

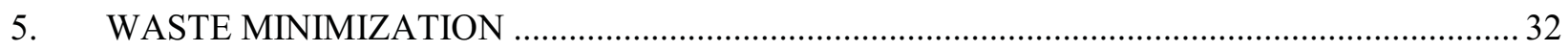

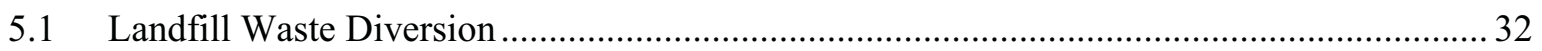

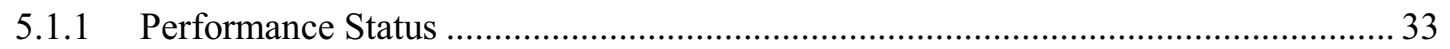

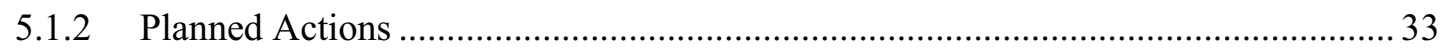

5.2 Construction and Demolition Waste Diversion ................................................................ 33

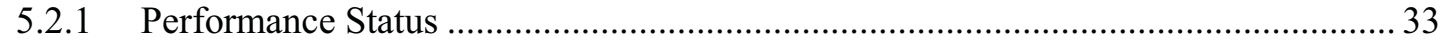

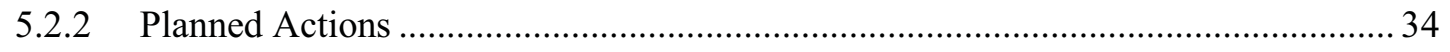

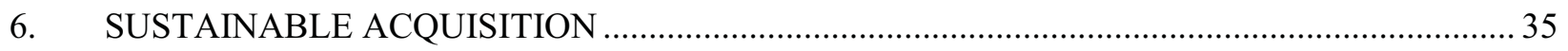



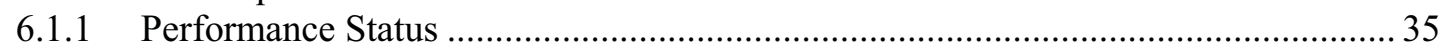

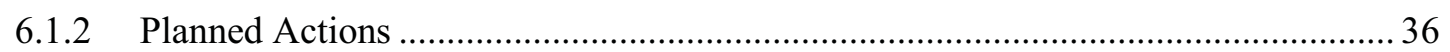

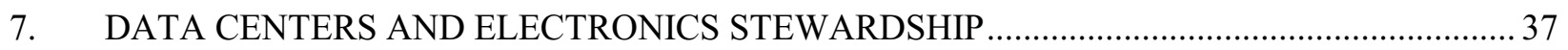

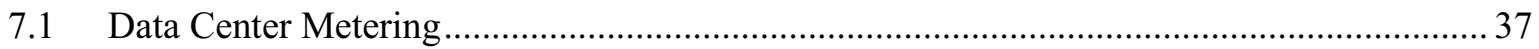

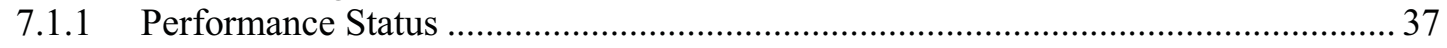

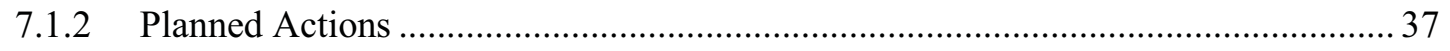

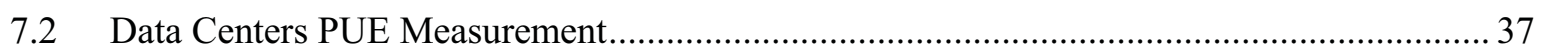

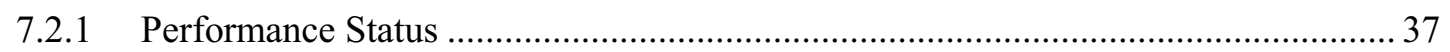

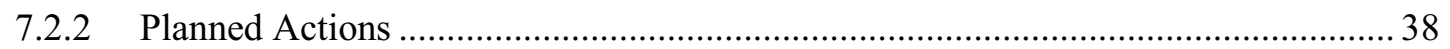

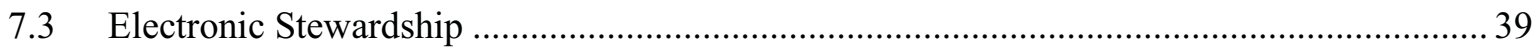

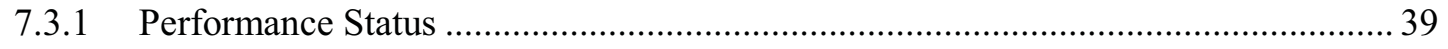

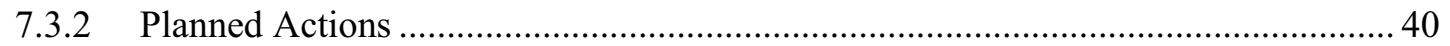

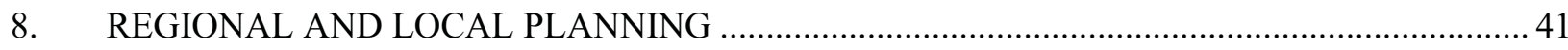

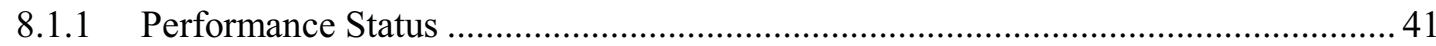

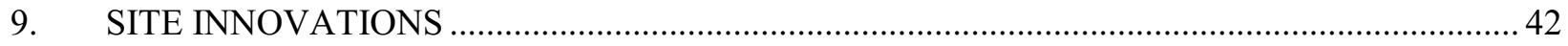

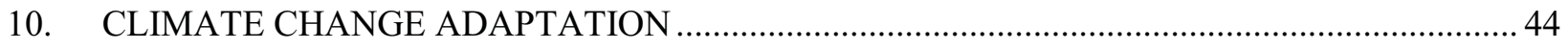

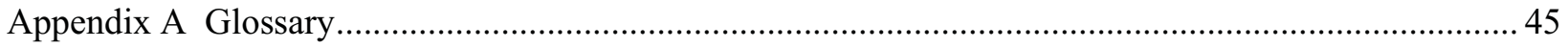

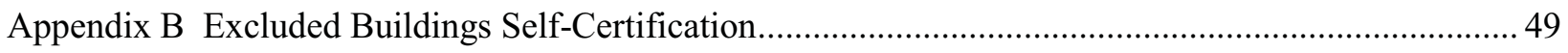

Appendix C Consolidated Energy Data Report (CEDR) …............................................................ 53

\section{FIGURES}

Figure ES-1. Current INL Site status to the DOE goals. ......................................................................ii 


\section{TABLES}

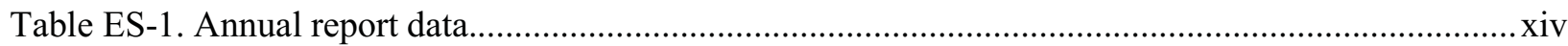

Table 1. INL Site Scope 1 and 2 GHG calculation results for FY 2008 and FY 2011, and the FY

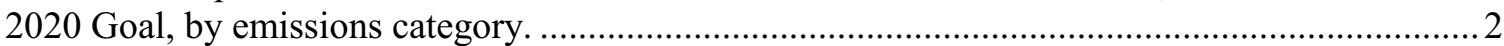

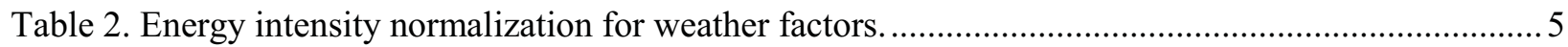

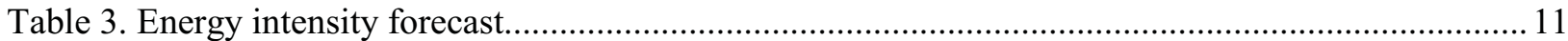

Table 4. INL Site Scope 3 GHG calculation results for FY 2008 and FY11, and the FY 2020

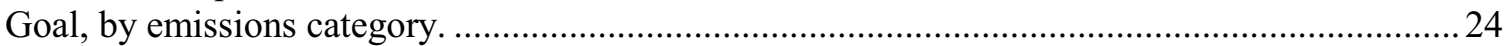

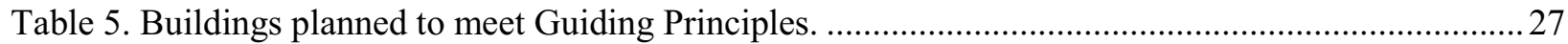

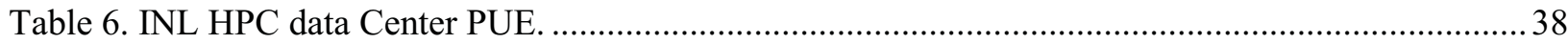


(This Page Intentionally Left Blank)

xxvi 


\section{ACRONYMS}

AFV alternative fuel vehicle

AMWTP Advanced Mixed Waste Treatment Project

ARRA American Recovery and Reinvestment Act

ATR Advanced Test Reactor

BEA Battelle Energy Alliance, LLC

BPA Bonneville Power Administration

Btu British thermal unit

C\&D Construction and Demolition

CAES Center for Advanced Energy Studies

CD-2 Conceptual Design

CDP Calcine Disposition Project

CEDR Consolidated Energy Data Report

CFA Central Facilities Area

CNG Compressed Natural Gas

CRAC Computer Room Air Condition

CUI controlled unclassified information

D\&D Decontamination and Dismantlement

DOD Department of Defense

DOE Department of Energy

DOE-ID Department of Energy Idaho Operations Office

DRI Desktop Refresh Initiative

E-85 Ethanol 85 (alternative fuel that is $85 \%$ ethanol and $15 \%$ gasoline)

EBR-I Experimental Breeder Reactor 1

ECM Energy Conservation Measure

EM Environmental Management

EMS Environmental Management System

EO Executive Order

EPA Environmental Protection Agency

EPEAT Electronic Product Environmental Assessment Tool

EROB Engineering Research Office Building

ESCo Energy Services Contractor

ESL Energy Systems Laboratory

ESPC Energy Savings Performance Contract 
FAST Fleet Automotive Statistical Tool

FEC Federal Electronics Challenge

FEMP Federal Energy Management Program

FIMS Facilities Information Management System

FIRP Facility Infrastructure Revitalization Program

FY Fiscal Year

GHG greenhouse gas

GIS Geospatial Information System

GP Guiding Principle

GPS Global Positioning System

GSA General Services Administration

GSF Gross Square Feet

HDD Heating Degree Days

HEV hybrid electric vehicle

HPC High Performance Computing

HPSB high performance and sustainable building

HQ Headquarters

HWMA Hazardous Waste Management Act

ICP Idaho Cleanup Project

ILA industrial, landscaping, and agricultural

IM Information Management

INL Idaho National Laboratory

INTEC Idaho Nuclear Technology and Engineering Center

IORC Information Operations and Research Center

IRC INL Research Center

ISMS Integrated Safety Management Systems

IT Information Technology

IWTU Integrated Waste Treatment Unit

LCD Liquid Crystal Display

LEED $^{\mathrm{TM}} \quad$ Leadership in Energy and Environmental Design

LNG Liquefied Natural Gas

MFC Materials and Fuels Complex

MIT Massachusetts Institute of Technology

MT metric tons

MTR Materials Test Reactor 
NRF Naval Reactors Facility

OMB Office of Management and Budget

ORNL Oak Ridge National Laboratory

PDU Process Demonstration Unit

PHEV Plug-in Hybrid Electric Vehicle

PNNL Pacific Northwest National Laboratory

PUE Power Utilization Effectiveness

R\&D Research and Development

RAMP Roof Asset Management Program

RCRA Resource Conservation and Recovery Act

RDD\&D Research, Development, Demonstration, and Deployment

REC Renewable Energy Certificate

REL Research and Education Laboratory

RESL Radiological Environmental Sciences Laboratory

RFI Request for Information

RFID Radio Frequency Identification

RFP Request for Proposal

ROB Research Office Building

RWMC Radioactive Waste Management Complex

SMC Specific Manufacturing Capability

SSPP Strategic Sustainability Performance Plan

TSB Technical Support Building

TTAF Test Train Assembly Facility

TYSP Ten-Year Site Plan

UESC Utility Energy Savings Contract

UPS Uninterruptable Power Supply

USGBC United States Green Building Council

VAM Vehicle Allocation Methodology

VM Virtual Machine

WAPA Western Area Power Administration

WCB Willow Creek Building 
(This Page Intentionally Left Blank) 


\section{FY 2012 INL Site Sustainability Plan with the FY 2011 Annual Report \\ 1. GOAL PERFORMANCE REVIEW AND PLANS}

For the purposes of this document, the "INL Site" is considered all operating contractors and the Department of Energy Idaho Operations Office (DOE-ID), and includes the industrial complexes located west of Idaho Falls and the Idaho Falls buildings. Idaho National Laboratory (INL) is considered to be those facilities operated by Battelle Energy Alliance, LLC (BEA). The Advanced Mixed Waste Treatment Project (AMWTP) and Idaho Cleanup Project (ICP) are referred to by their noted acronyms and include all facilities under their individual responsibility.

The Environmental Management Mission assumptions for this Plan include the Advanced Mixed Waste Treatment Project (AMWTP) ceasing operations and be in a cold, dark, and dry status by FY 2018; the remaining Idaho Cleanup Project (ICP) operations at the Radioactive Waste Management Complex (RWMC) will be complete by FY 2018 with buildings in a cold, dark and dry status; the Idaho Nuclear Technology Center (INTEC) liquid waste management system operations will be discontinued by FY 2015; and the INTEC New Waste Calcine Facility will be demolished by FY 2015.

\subsection{Scopes 1 and 2 Greenhouse Gas Reduction}

\section{8\% Scope 1 \& 2 GHG reduction by FY 2020 from a FY 2008 baseline.}

Executive Order (EO) 13514 mandates that agencies develop specific greenhouse gas (GHG) reduction targets. Department of Energy (DOE) has set a reduction target of 28\% for Scope 1 and 2 GHGs. The EO sets Fiscal Year (FY) 2008 as the baseline year against which reductions will be measured.

The INL Site reported Scope 1 and Scope 2 GHG emissions for the baseline year, FY 2008, and annually thereafter. Scope 1 and Scope 2 are defined as:

- Scope 1. Direct or INL Site-owned emissions that are produced onsite, such as stationary combustion (from fuel combustion), mobile combustion (from fleet vehicles), and fugitive emissions (from refrigerants, onsite landfills, and onsite wastewater treatment). These include emissions that may benefit another entity or contractor, but for which the INL Site controls or owns the associated process.

- Scope 2. Indirect or shared emissions produced by INL Site's electricity, heat, and steam purchases. (Note that INL Site did not purchase heat or steam during FY 2009 through FY 2010.)

The INL Site contractors' Environmental Management Systems (EMS) provide the framework and process for evaluating and monitoring Scopes 1, 2, and 3 GHG emissions and related reduction activities. On an annual basis, appropriate sustainability targets are developed and monitored through the EMS to support the overall reduction in GHG emissions.

The challenge is to minimize the impact of operations while increasing the growth of the Laboratory, balanced with EM closure activities. The INL Site is integrating environmental performance improvement in the areas that matter most to its stakeholders and the Laboratory, including minimizing the environmental footprint, taking a progressive approach to climate change, and championing energy conservation. 


\subsubsection{Performance Status}

Based on data entered into the CEDR for FY 2011, the INL Site has reduced Scope 1 greenhouse gas emissions 24.8\%. (FY 2008 - 35,176.84 MT CO $\mathrm{CO}_{2} \mathrm{e}$ and FY $2011-26,456.46 \mathrm{MT} \mathrm{CO}_{2} \mathrm{e}$ ), reduced Scope 2 greenhouse gas emissions 9.5\% (FY 2008 - 94,919.29MT $\mathrm{CO}_{2} \mathrm{e}$ and FY $2011-85,941.06 \mathrm{MT} \mathrm{CO}_{2} \mathrm{e}$ ). The combined Scope 1 and Scope 2 emissions decreased 22.5\% in FY 2011 as reported by the SPO.

INL completed an update to the FY 2008 GHG baseline based on updated guidance. Minimal changes occurred as a result of this update. Additionally, INL completed comprehensive inventories for FY 2009 and FY 2010.

As found in Table 1, each Scope 1 and Scope 2 category is listed for FY 2008 and FY 2011 and the calculated emission needed for each by FY 2020. FAST data, a Scope 1 emission, is not included in this table.

Table 1. INL Site Scope 1 and 2 GHG calculation results for FY 2008 and FY 2011, and the FY 2020 Goal, by emissions category.

\begin{tabular}{|c|c|c|c|c|}
\hline Scope & Emissions Category & $\begin{array}{l}\text { FY } 2008 \text { Baseline } \\
\left(\mathrm{MT} \mathrm{CO}_{2} \mathrm{e}\right)\end{array}$ & $\begin{array}{l}\text { FY } 2011 \text { Actual } \\
\left(\mathrm{MT} \mathrm{CO}_{2} \mathrm{e}\right)\end{array}$ & $\begin{array}{c}\text { FY } 2020 \\
\text { Reduction Goal } \\
\left(\mathrm{MT} \mathrm{CO}_{2} \mathrm{e}\right) \\
\end{array}$ \\
\hline \multirow[t]{5}{*}{1} & Stationary Combustion & $28,590.9$ & $19,886.7$ & $20,585.5$ \\
\hline & $\begin{array}{l}\text { Fugitive Emissions: } \\
\text { Refrigerants }\end{array}$ & 332.4 & 606.5 & 239.3 \\
\hline & $\begin{array}{l}\text { Fugitive Emissions: Onsite } \\
\text { Landfill }\end{array}$ & $5,972.4$ & 5702.1 & 4300.1 \\
\hline & $\begin{array}{l}\text { Fugitive Emissions: Onsite } \\
\text { Wastewater Treatment }\end{array}$ & 281.1 & 261.2 & 202.4 \\
\hline & Scope 1 Total & $35,176.8$ & $26,456.5$ & $25,327.3$ \\
\hline 2 & $\begin{array}{l}\text { Purchased Electricity } \\
\text { (includes owned } \\
\text { Transmission \& } \\
\text { Distribution Losses) }\end{array}$ & $94,919.3$ & $85,941.1$ & $68,341.9$ \\
\hline $1 \& 2$ & Grand Total & $130,096.1$ & $112,397.5$ & $93,669.2$ \\
\hline
\end{tabular}

Many factors influence the INL Site's GHG emissions, including the large land area on which the Laboratory's facilities are located. The area requires long commutes and an extensive fleet to provide transportation for desert site workers, and contains many antiquated inefficient facilities built before the current appreciation for energy efficiency and high-performance design. These factors tie directly into the following conclusions from the INL Site's baseline GHG inventory:

- Electricity is the largest contributor to the INL Site's GHG inventory, with over $60 \%$ of the net anthropogenic CO2e emissions from Scopes 1 and 2

- Other sources with high emissions were stationary combustion, and fugitive emissions from the onsite landfills

- Among the sources with low emissions within Scopes 1 and 2 were fugitive emissions from refrigerants and onsite wastewater treatment. 


\subsubsection{Planned Actions}

The INL Site will continue to implement projects that reduce electricity and fuel usage, reducing corresponding Scope 1 and Scope 2 emission reductions. ICP will continue its closure mission, discontinuing processes and making facilities inactive and cold, dark and dry; or demolishing what is no longer needed. Knowing the target emission for each as found in the INL GHG Reduction Strategy helps prioritize and plan projects accordingly.

\section{Mobile Combustion Reduction tactics include:}

- Take advantage of mass transportation and shuttles

Significant petroleum reduction and associated GHG reduction could be realized by moving the AMWTP contract force away from the current vanpool system to the existing INL bus operation. A majority of the AMWTP work force could be absorbed into the current bus operations schedule (i.e., fill the empty seats on buses currently traveling to/from the Site).

- Consolidate trips.

INL is working with the Idaho Transportation Department to establish a ride-share pool for INL employees.

INL has consolidated buses used to shuttle shift workers and bus drivers into the regular INL shuttle schedule. In addition, INL monitors shuttles and other runs, and eliminates or consolidates runs with low utilization.

- Eliminate trips by using tools such as video and Web conferencing for meetings.

The use of "Go to Meeting" and other similar Web conferencing tools are available and use is expanding at INL.

- Use alternative modes of transportation such as bicycles and low-speed vehicles as appropriate.

Low-speed vehicles are available and in use inside Site areas.

Bicycle pools could be established for transportation between town campuses using a model implemented by Oak Ridge National Laboratory (ORNL).

- Provide right size fleet.

Decrease the number of "permanently assigned" vehicles and consolidate vehicles into pools located at major INL Site campuses. Implement an automated pool check-out/check-in system such as the Asset Works "Key-Valet" system that is compatible with the current INL vehicle reservation system.

Restrict use of Site fleet to Site activities. For example, vehicles needed for environmental monitoring would be based at the Site locations and trips would start/end from ATR, CFA, MFC, etc., and not be used to transport employees to/from Idaho Falls. Employees could use bus routes and shuttles to travel between town and Site.

\section{Fugitive emission reduction tactics include:}

- Work with recycling coordinator to identify waste diversion opportunities, including increasing the types and quantities of items sent for recycling, and implementing composting. These activities will assist with meeting the EO 13514 waste diversion goals.

- Investigate installing a gas collection system at the onsite landfill to use as an energy source.

- Electricity emission reduction tactics include installing onsite renewable energy projects as cost effective, although there are no plans or funding to install in the near term. 
- Use the following tactics to reduce direct purchased electricity:

- Install smart meters in Idaho Falls buildings (scheduled for FY 2012)

- Satisfy sustainable acquisition requirements to purchase Energy Star and Federal Energy Management Program (FEMP) devices (EO 13514 requirement)

- Meet green building goals for new and existing buildings (Guiding Principles and Leadership in Energy and Environmental Design $\left[\mathrm{LEED}^{\mathrm{TM}}\right]$ Gold certification)

- Continue educational campaign to change employee behaviors (turn off lights and computers when leaving at end of shift, utilize power management when available, avoid using space heaters, personal fridges, etc.)

- $\quad$ Continue to pursue Energy Savings Performance Contract (ESPC) Contract 3

- $\quad$ Upgrade Idaho Falls facilities using either Utility Energy Savings Contract (UESC) funds or internal upgrade program.

- REC purchase increase tactic:

- The INL Site will continue to meet the minimum requirements of purchasing $7.5 \%$ of the electric energy usage in equivalent RECs. However, INL has committed to increase purchase of RECs starting in FY 2012 to 10\% of the INL electric usage. Although the increase does not contribute to the GHG reduction goal, it does demonstrate INL's commitment to climate change adaptation and strategic leadership. The calculation method is based on the following: assume $10 \%$ of the previous year's purchased electricity total will be purchased as RECs in the current year (i.e., FY 2012 REC purchase is 10\% of FY 2011 total purchased electricity).

\subsection{Energy Intensity Reduction}

\section{0\% energy intensity reduction by FY 2015 from a FY 2003 baseline.}

The INL Site goal for energy usage is a 30\% reduction of energy intensity by FY 2015, as compared to the FY 2003 energy intensity baseline. Energy intensity is defined as energy use divided by building area and is measured in Btu/ $\mathrm{ft}^{2}$. On average, an annual energy use reduction goal of $3 \%$ supports meeting the overall goal and provides a means to measure and trend progress. Energy intensive loads that are mission specific are excluded from the goal. The ATR and its support facilities are currently excluded from the reporting goal but are not excluded from the responsibility to reduce energy use and GHGs where practicable.

Energy sources affected by this goal include electricity, natural gas, fuel oil, liquefied natural gas (LNG), and propane. Methods to reduce energy usage include capital project upgrades, operational modifications, and behavior changes by the INL workforce.

The INL Site energy intensity for FY 2011 was $173,194 \mathrm{Btu} / \mathrm{ft}^{2}$ as compared to $183,471 \mathrm{Btu} / \mathrm{ft}^{2}$ in FY 2003 for a calculated reduction of 5.6\%. This reduction falls far short of the desired $18 \%$ cumulative reduction goal for FY 2011. However, the INL Site normalizes energy intensity each year to provide for a weather-related adjusted comparison with the base year. To make this correction, the portion of energy used for space conditioning (defined as $43 \%$ of the total according to DOE's Energy Information Administration) is adjusted to the weather conditions for the base year. In FY 2011, there were 8,970 Heating Degree Days (HDDs) as compared to only 7,892 in FY 2003. In this comparison, the energy intensity would decrease had temperatures been as warm in FY 2011 as they were in FY 2003. The result is a corrected energy use intensity of $164,244 \mathrm{Btu} / \mathrm{ft}^{2}$, and when compared to the base year energy intensity of $183,471 \mathrm{Btu} / \mathrm{ft}^{2}$, it calculates to an actual $10.5 \%$ reduction (see Table 2 ). 
Table 2. Energy intensity normalization for weather factors.

\begin{tabular}{|c|c|c|c|c|}
\hline $\begin{array}{c}\text { Energy Intensity } \\
\text { FY } 2003\end{array}$ & $\begin{array}{c}\text { Energy Intensity } \\
\text { FY } 2011\end{array}$ & $\begin{array}{l}\text { HDDs } \\
\text { FY } 2003\end{array}$ & $\begin{array}{c}\text { HDDs } \\
\text { FY } 2011\end{array}$ & $\begin{array}{c}\text { Normalized Energy } \\
\text { Intensity FY } 2011\end{array}$ \\
\hline $183,471 \mathrm{Btu} / \mathrm{ft}^{2}$ & $173,194 \mathrm{Btu} / \mathrm{ft}^{2}$ & 7,892 & 8,970 & $164,244 \mathrm{Btu} / \mathrm{ft}^{2}$ \\
\hline (Baseline Year) & $\begin{array}{l}\text { (5.6\% Reduction } \\
\text { from FY 2003) }\end{array}$ & $\begin{array}{l}\text { (Baseline } \\
\text { Year) }\end{array}$ & $\begin{array}{c}\text { (Over 1,000 } \\
\text { HDD increase) }\end{array}$ & $\begin{array}{l}\text { (10.5\% Reduction } \\
\text { from FY 2003) }\end{array}$ \\
\hline
\end{tabular}

Due to the nature of the various INL Site missions, many operations can be cyclical and result in varying usages of energy. As facilities are removed or processes are modified, the INL Site energy usage intensity can vary seemingly unrelated to actual overall reduction efforts. In FY 2011, additional Decommissioning and Demolition (D\&D) work continues to remove low energy use facilities operating in a standby mode. As the INL Site square footage decreased, the energy use intensity did not decrease as much as desired, even though total energy use declined.

There is one major new project under development at the ICP. Construction of the Integrated Waste Treatment Unit (IWTU) was completed in FY 2011 and houses the treatment process for treating the remaining wastes in the Tank Farm Facility. This treatment process is slated to begin hot operations in second quarter of FY 2012. The treatment process will use significant amounts of water and electricity. The facility does not currently have the capability for individual building metering and is captured in the overall Idaho Nuclear Technology Center (INTEC) metering. While an increase in INTEC energy use will occur, this process is expected to operate for less than 1 year to complete its mission, at which time the facility energy use should decrease back to the current INTEC load. When the IWTU becomes operational, it will be included on the INL Site Excluded Facilities input.

A future facility is currently being designed for the treatment of the calcine solids stored in the Calcine Solids Storage Facility located at INTEC. The Calcine Disposition Project (CDP) is planning to use a portion of the IWTU facility for this project. The CDP will also be an energy intensive treatment process that could be operational by FY 2020. The CDP will have individual energy metering capability and the expectation is that this facility will be exempted from the energy reduction goals. The energy metering capability will enable the facility use to be subtracted from the overall INTEC use so that progress on energy reduction at INTEC can be monitored.

The INL Site is planning for significant growth to further its missions with additional process related facilities at the major desert site locations and additional office and laboratory facilities at Idaho Falls locations. The INL TYSP (DOE/ID-11449) provides an overview and details of conceptual laboratory growth. Several of these new facilities are identified in the New Buildings worksheet of the Consolidated Energy Data Report (CEDR).

\subsubsection{Performance Status}

To meet the Strategic Sustainability Performance Plan (SSPP) energy goal, the INL Site should be at an $18 \%$ reduction by the end of FY 2011 as compared to the established FY 2003 baseline. As demonstrated through data entered into the CEDR and corrected for weather related factors, the INL Site is actually at a $10.5 \%$ in energy reduction, which also represents a $1.1 \%$ reduction from FY 2010.

INL made progress in FY 2011 with final construction of the MFC ESPC project. Additional energy reductions will be realized in FY 2012 after a full year of operations of the new boilers. 


\subsubsection{Planned Actions}

ICP will contribute to energy intensity reductions in two primary ways. ICP has reduced building footprint by $857,428 \mathrm{ft}^{2}$ since FY 2003 and is discontinuing operations which reduces energy consumption. Additional projects such as the roof upgrades and heating system upgrades will also be completed in the near future.

The INL Site capital project upgrades are funded primarily through alternative funding mechanisms that include ESPC and UESC. They both use external (non-DOE) funding for energy-related upgrades and are paid back over time using the energy cost savings generated by the project. Both are time consuming and have requirements that limit effectiveness. The UESC process commenced on several owned and leased Idaho Falls facilities, but a major program requirement states that the payback must not exceed the length of the building lease. This greatly limits implementation as most leased facilities have 5 to 10 year leases and most payback calculations are 7 to 15 years. Still, the INL Site is actively pursuing these two alternative funding strategies to obtain additional energy savings. Finally, the INL Site will maximize the use of available utility incentive programs to help fund both internal and alternatively funded projects.

INL will supplement the ongoing ESPC project by providing Strategic Investment Funding (SIF) to implement projects that are either not readily adaptable to ESPC projects, or directly influence the efficiency of buildings that INL is pursuing the Guiding Principles. The SIF will be provided for each year through FY 2015. Site:

The following projects were identified that will contribute to continued energy reductions for the INL

- Using SIF for FY 2012, installation of up to nine energy and water reduction projects in Willow Creek Building (WCB), Engineering Research Office Building (EROB), and the Research Office Building (ROB). These projects were developed during FY 2011 for implementation in FY 2012.

1. WCB Chiller Replacements

2. EROB $\mathrm{CO}_{2}$ Controls

3. WCB Water Fixture Replacements

4. IRC (IF-602) Water Fixture Replacements

5. WCB Lighting Fixtures

6. WCB Lighting Controls

7. WCB Exterior Lighting Fixtures

8. ROB (IF-601) Exterior Lighting Fixtures

9. IRC (IF-603) Motor/Controls.

- ESPC development continues including completion of the Investment Grade Audit for all enduring facilities at CFA, ATR-Complex, and selected facilities at the Specific Manufacturing Capability (SMC) facility. Energy Conservation Measures (ECM) being pursued include lighting, HVAC, and building envelope upgrades, boiler plant elimination at CFA, boiler plant controls at SMC, back generator installation at ATR Complex, solar walls, and possibly small renewable energy generation.

- A fourth ESPC project is estimated to cost \$42-\$52M based on historical data from ESPC 1 and ESPC 2.

- ICP planned actions for energy reduction activities after FY 2011 consist of continued D\&D, which will result in a projected net reduction of building square footage for the INL Environmental Management (EM) program by the end of FY 2020 of 118,218 $\mathrm{ft}^{2}$. AMWTP completion will place 12 
facilities in a cold, dark, and dry status. ICP will complete several processing operations including ceasing operations of the Liquid Waste Management System.

- An ESPC was initiated for EM operations at INTEC, but was put on hold due to uncertainties with building lifetimes.

INL identified several projects that would contribute to the goal, but are either not economical or payback calculations prohibit installation based on DOE-HQ guidance. Projects are at numerous Idaho Falls facilities, leased and owned. Total estimated cost for the following 59 projects is $\$ 12.7 \mathrm{M}$. Project include:

- Replace three 20 ton, RTU-style single package system with three variable volume systems with and ARI Energy Efficiency Rating (EER) of 12.0 (13.1 IPLV) and with a gas heating efficiency of 82\%.

- Replace one 3 ton, two 7.5 ton, and one 10 ton heat pumps with new high efficiency heat pumps with a minimum Coefficient of Performance of 4.0 .

- Replace the existing four heat pumps with new high efficiency heat pumps with a coefficient of performance of 4.0 .

- Install air-to-air heat exchangers in each of the three HVAC zones with a minimum of 100, 300, and 750 CFM.

- Install new 5hp VFDs on the MOAU-1 and MOAU-2 fan motors and program/control with the new $\mathrm{CO}_{2}$ sensors.

- Install destratification fans and infrared heaters in each of the two high bay areas to circulate the air and eliminate temperature stratification.

- Replace 15 exterior wall pack fixtures with new 9W LED Fixtures.

- Replace 11 walkway lights with new 9W LED lamps and eight parking lot fixture heads with new $30 \mathrm{~W}$ LED or $250 \mathrm{~W}$ induction lamp fixture heads.

- Replace 17 exterior wall pack fixtures with new 6W LED Fixtures

- Replace 15 exterior wall pack fixtures with new 28W LED fixtures and 12 single-light and four double-light parking lot fixture heads with sixteen 60W LED or $400 \mathrm{~W}$ induction lamp fixture heads.

- Replace 13 exterior wall pack fixtures with new 20W LED fixtures and seven parking lot fixture heads with new $60 \mathrm{~W}$ LED or $300 \mathrm{~W}$ induction lamp fixture heads.

- Replace seven exterior wall pack fixtures with new 20W LED fixtures.

- Replace 65 exterior light fixtures with twenty-six 9W LED, eleven 60W LED or 100W induction lamp, four 20W LED, seven $30 \mathrm{~W}$ LED, and seventeen $100 \mathrm{~W}$ LED or $300 \mathrm{~W}$ induction lamp fixtures.

- Replace 12 exterior light fixtures with new 9W LED fixtures.

- Replace 10 exterior light fixtures with new 9W LED fixtures.

- Replace 27 exterior wall pack fixtures with eleven $25 \mathrm{~W}$, fourteen $28 \mathrm{~W}$, and two $30 \mathrm{~W}$ new LED fixtures. Replace 43 parking lot fixture heads with new 100W LED or 250W induction lamp fixture heads.

- Replace seven exterior wall pack fixtures with new 9W LED fixtures.

- Replace 11 exterior wall pack fixtures with new 9W LED fixtures.

- Replace eight exterior wall pack fixtures with new 39W LED fixtures.

- Replace six exterior wall pack fixtures with new 9W LED fixtures. 
- Install 118 wall and ceiling mount occupancy sensors for lighting control in offices, break rooms, rest rooms, conference rooms, and electrical and mechanical rooms.

- Install 133 wall and ceiling mount occupancy sensors for lighting control in offices, break rooms, conference rooms, and mechanical rooms.

- Retrofit 1,118 T12 fluorescent fixtures with new electronic ballasts and T8 lamps.

- Retrofit two hundred twenty-seven 40 and $60 \mathrm{~W}$ task and spotlights with $12 \mathrm{~W}$ compact fluorescent lamps.

- Retrofit 170 fluorescent fixtures with new electronic ballasts and T8 lamps. Replace 15 exit sign fixtures with new LED fixtures.

- Install 14 wall and ceiling mount occupancy sensors for lighting control.

- Replace one $1 \mathrm{hp}$ and one $30 \mathrm{hp}$ pump motors with new premium efficiency motors.

- Replace two $2 \mathrm{hp}$, four $3 \mathrm{hp}$, eight $5 \mathrm{hp}$, six $7.5 \mathrm{hp}$, six $10 \mathrm{hp}$, four $15 \mathrm{hp}$, four $20 \mathrm{hp}$, one $25 \mathrm{hp}$, six $30 \mathrm{hp}$, two $40 \mathrm{hp}$, and one $50 \mathrm{hp}$ motors with new premium efficiency motors.

- Replace one $3 \mathrm{hp}$, three $7.5 \mathrm{hp}$, four $15 \mathrm{hp}$, one $20 \mathrm{hp}$, and two $25 \mathrm{hp}$ motors on end suction pumps with new high efficiency motors.

- $\quad$ Replace three $5 \mathrm{hp}$, seven $7.5 \mathrm{hp}$, four $10 \mathrm{hp}$, four $20 \mathrm{hp}$, two $30 \mathrm{hp}$, and one $40 \mathrm{hp}$ in-line fan motors with new high efficiency motors.

- $\quad$ Replace one $1 \mathrm{hp}$, one $1.5 \mathrm{hp}$, one $3 \mathrm{hp}$, and one $5 \mathrm{hp}$ general-purpose fan motors with new highefficiency motors.

- Install one VFD on the 5hp HVAC motor on the single package RTU and three 7.5hp fan motors.

- Install one 7.5hp VFD on P-2, one 15hp VFD on P-4, one 20hp VFD on CT-1, one 40hp VFD on CT2, two 15hp VFDs on the main hot water heating pumps, and two 10hp VFDs on the Data Pump House condenser pumps.

- Replace the current boiler with a new High Efficiency Condensing Boiler. The boiler capacity will be increased from 1,400 MBH to 2,000 MBH. (Consider several small packaged boiler-system efficiency and mechanical room access).

- Install VFDs on pump motors and HVAC motors for air handlers 1-6, cooling systems and hot water heating system pumps, heat recovery system pumps and cooling tower fan motors and upgrade Carrier I-VU controls to facilitate control of the new VFDs.

- Install usage based controls (UBC) variable flow Carrier I-VU proximity controls on the lab fume hoods 72 and new Carrier I-0VU controls for the existing Phoenix airflow control valves 237, for the lab area with electronic to pneumatic transducers.

- Replace the existing boilers with new High Efficiency Condensing Boilers capable of 5,000 MBH.

- Replace the existing and install one additional evaporative fluid-cooling tower, replace the associated two heat exchangers with two new plate and frame system heat exchangers and modify controls.

- Install 35 ground-mounted flat plate type solar collector heating panels to heat the water in one of the existing 56k gallon hot water storage tanks. This system would use glycol for heat transfer to a new 350-gpm pump system and heat exchanger.

- Replace one 5 ton, two 10 ton, one 12.5 ton, and eight 15 ton RTUs with new high efficiency natural gas/scroll compressor RTUs with an EER of 11 or above, variable speed fan control, modulating heating/cooling, economizers, and $12 \mathrm{CO}_{2}$ sensor controls. 
- Remove five return air fans that are no longer required and increase the size of the return air ducting to reduce pressure drop.

- Install a new Carrier I-VU HVAC and Lighting control system for the entire building including five new lighting control panels.

- Add one Lieber Glycool second economizer cooling coil and controls to all nine of the existing Liebert systems.

- Replace two 2.5 ton, two 5 ton, two 6 ton, four 10 ton, one 15 ton, one 20 ton, and one 25 ton rooftop units (RTU) with new high efficiency units with economizers, $\mathrm{CO}_{2}$ demand control ventilation, and electronic programmable controls (one space at a time).

- Enlarge the return air duct system for AC-24 and AC-25 serving the Enterprise Server room to address a recurring freeze problem during the heating season. Verify correct airflow through fire dampers and rebalance entire system.

- Convert the ceiling plenum supply system for the office areas into a ducted supply system for RTU units AC-11, 13, 14, 15, and 21 zones. This task will include 88 new diffusers, 32 return air grills, and $2,000 \mathrm{lbs}$ of duct work and accessories.

- Replace the roof on approximately two-thirds of the roof and install R30 insulation throughout.

- Install on all air handler coils, 2-way automatic modulating control valves to be plumbed to hot water and chilled water coils. Included are five 2.5 inch, seven 4 inch, and five 6 inch valves.

- Install VFDs on two $25 \mathrm{hp}$ chilled water loop pumps, one $7.5 \mathrm{hp}$ hot water loop pump, one $20 \mathrm{hp}$ hot water loop pump, and two $7.5 \mathrm{hp}$ cooling tower pumps.

- Reprogram control system to achieve savings offered by the above controls modifications.

- Replace the existing chillers with two new 250 ton variable speed drive chillers with an efficiency rating of at least $0.55 \mathrm{~kW} /$ ton and with a $0.365 \mathrm{~kW} /$ ton ARI IPLV efficiency rating.

- Install four $15 \mathrm{hp}$ VFDs on the chilled water and condenser water pumps.

- Replace the existing electric boiler with a new 3,000 MBH high-efficiency, gas fired condensing boiler with an efficiency rating of $94.1 \%$.

- Reprogram control system to achieve savings offered by the above equipment replacements.

- Remove the existing process hot water gas fired boiler, gas lines, and power feed.

- Retrofit 718 existing Kite Light fixtures with new 55W compact fluorescent lamps.

- Add nine new VAV boxes (approximately 3,000 CFM each), associated controls, and 5,800 lbs of additional galvanized steel ducting to split an existing nine zones into 18 zones to provide heating to areas served previously with the metal halide "kite lights".

- Install new glycol-to-chilled water heat exchangers and associated components on the two computer room/telecommunications room air conditioning units (Liebert/EdPac).

- Replace two single-stage $20 \mathrm{hp}$ air compressors with two new high efficiency single-stage $15 \mathrm{hp}$ variable speed drive, air-cooled, rotary screw compressors, and a 120 gallon receiver tank.

- Install a new second Liebert Glycool economizer cooling coil and controls to the glycol Drycooler system on the three Liebert data cooling systems. 


\subsubsection{Energy Intensity Projection}

INL prepared an Energy Intensity Status and Forecast for DOE-ID on November 22, 2011 outlining various infrastructure and operational changes expected by FY 2015. This forecast indicates that the overall energy intensity will likely be a $22 \%$ reduction using the entire project funding resources currently identified. This first $22 \%$ of the $30 \%$ energy reduction goal will be achieved by completing identified ESPC projects, commissioning new efficient facilities, shutting down unneeded and completed operations, and implementing various internally funded projects. However, the final $8 \%$ will require major investments to implement yet-to-be identified opportunities. Table 3 provides the energy intensity forecast for FY 2003 (baseline year), FY 2011, and the energy intensity forecast for FY 2015. 


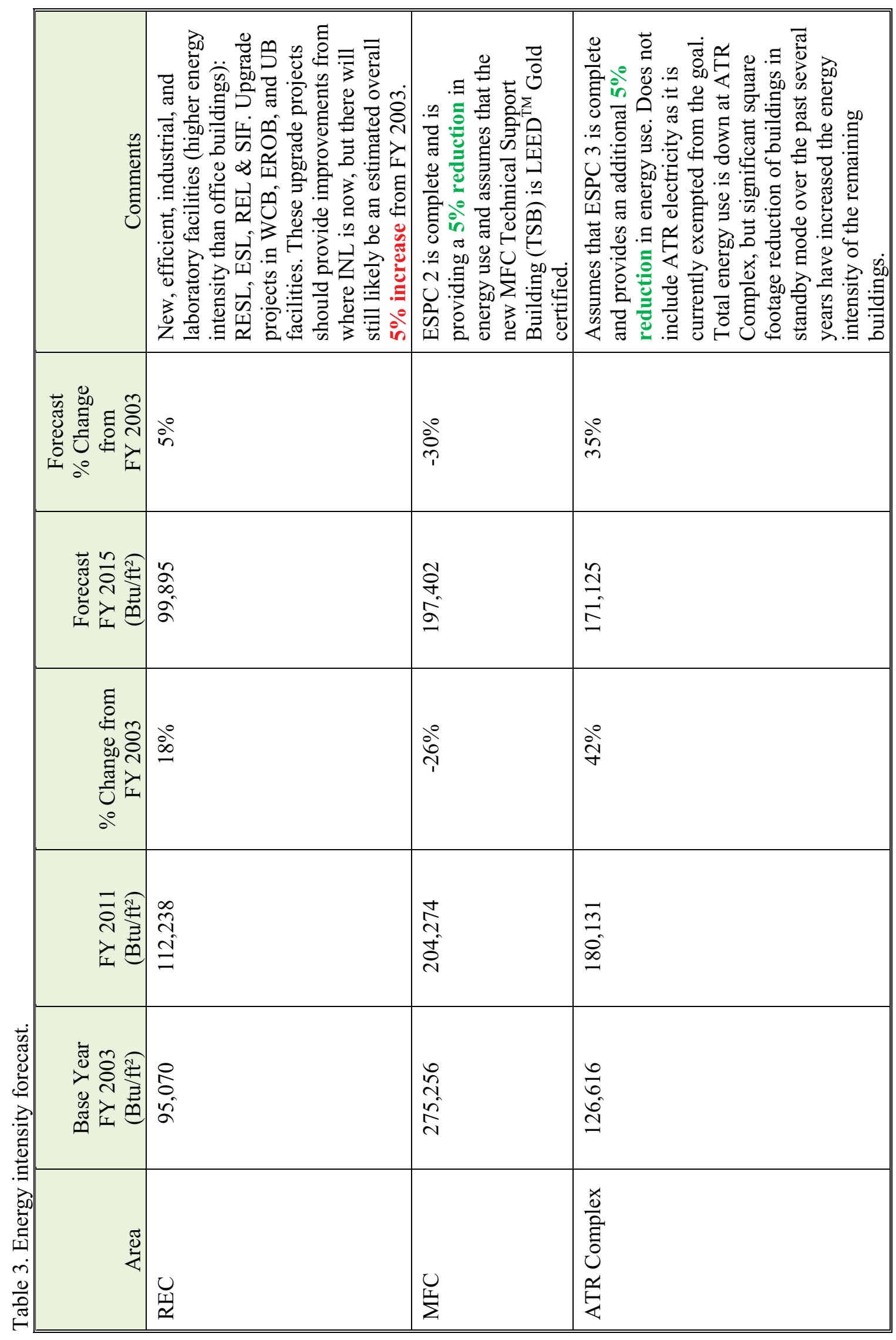




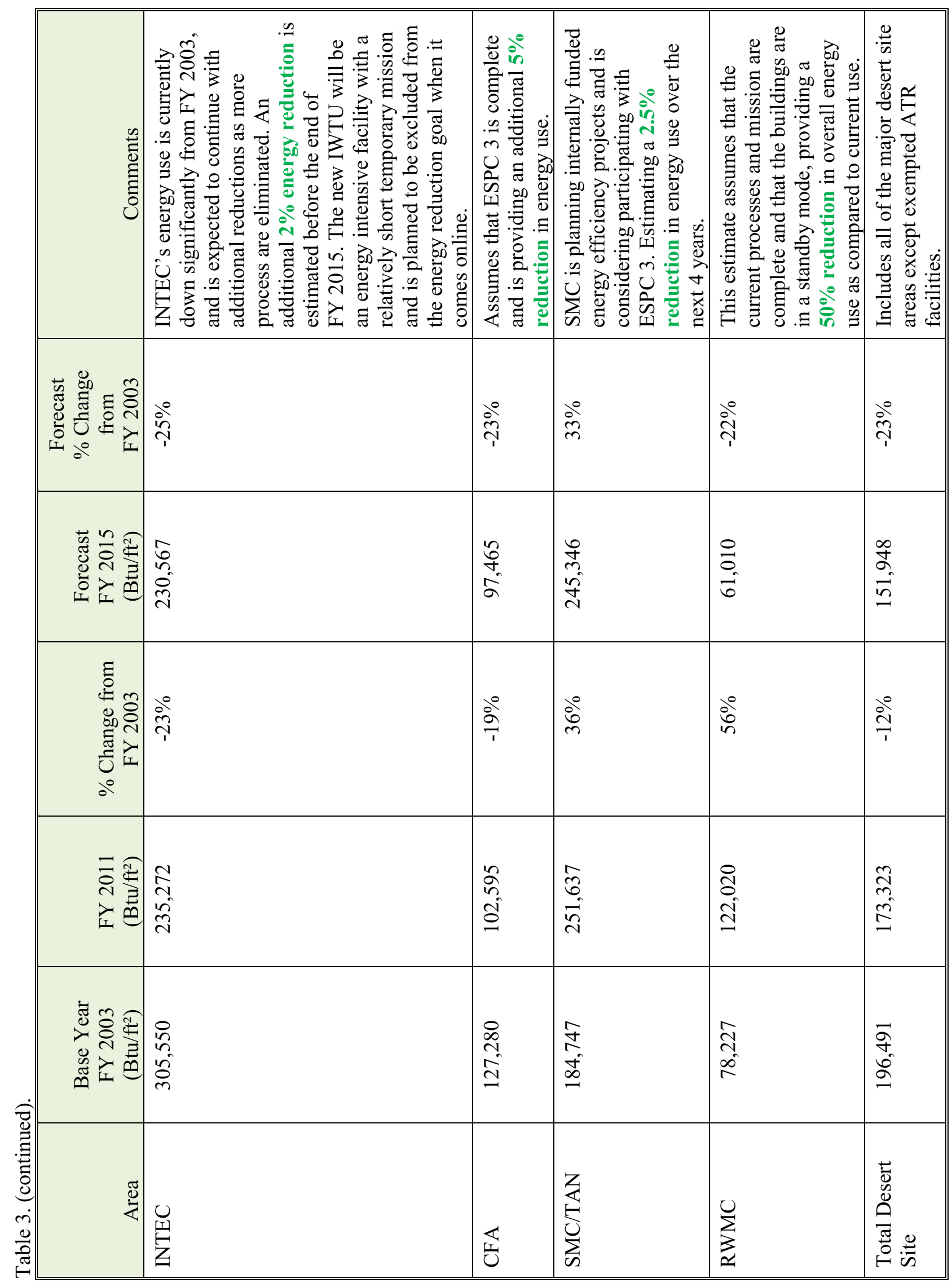



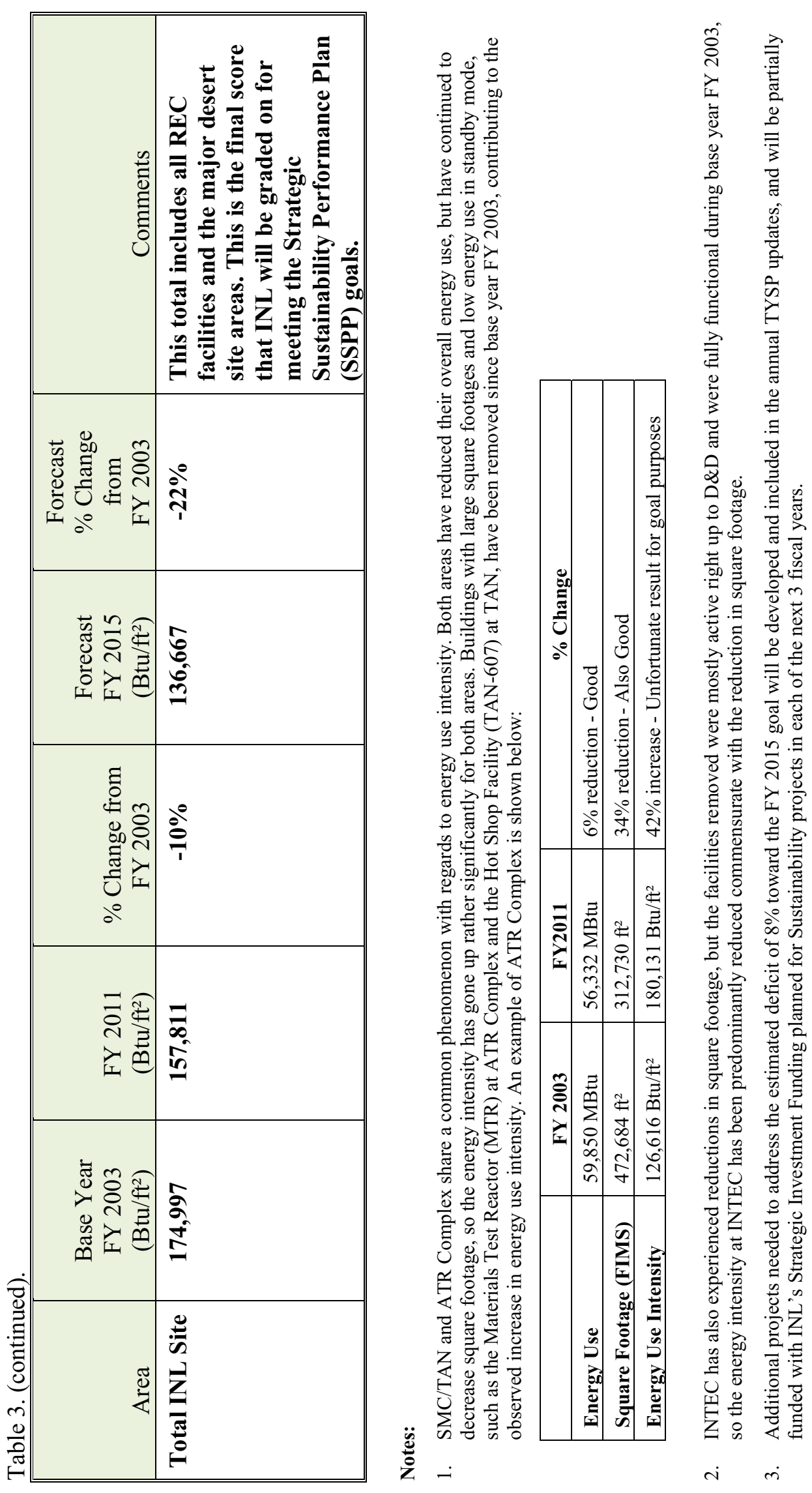


\subsection{Utility Metering}

Individual buildings or processes metering for 90\% of electricity (by October1, 2012); for 90\% of steam, natural gas, and chilled water (by October 1, 2015).

Most of the INL Site buildings do not have meters installed. Meter installation has been performed by groups of buildings or facility area. Meter installations will be prioritized by the potential of the building to meet the Guiding Principles and the cost effectiveness of installing meters to meet the $90 \%$ metering goal.

In the latest Facilities Information Management System (FIMS) snapshot, the INL Site has over 900 real property assets such facilities or structures, all of which potentially use electricity. Electric meter installation can cost anywhere from $\$ 5,000$ to over $\$ 25,000$ per asset. Installation across the entire INL Site is both uneconomical and unrealistic. The INL Site has chosen to use DOE guidance and economic analysis to determine the most logical buildings to meter.

\subsubsection{Performance Status}

Using a combination of the DOE Metering Guidance (memorandum from Jennifer C. MacDonald, Direct Sustainability Performance Office, May 6, 2011), the guidance for Electric Metering in Federal Buildings (DOE/EE-0312), the DOE Buildings Electric Metering Guidance of September 27, 2006, and the FEMP Metering Best Practices (October 2007), the INL FY 2011 Metering Plan (PLN-3911) was prepared to identify the appropriate buildings for installing new utility Metering.

The results were clear. The INL Site will only install meters on facilities that have the greatest potential of achieving Guiding Principle compliance, are great then $5,000 \mathrm{ft}^{2}$, are not cold, dark, and dry, will be in use after FY 2020, and are not exempted from reporting.

The total electricity being metered for the entire INL Site is $53 \%$ with plans in place to meter $90 \%$ by FY 2015.

All INL Idaho Falls town locations are currently metered 100\% for electricity and natural gas. In FY 2011, advanced metering was installed on the INL Research Center (IRC) Records Storage Facility (IF-663), the Research Office Building connected to the new Radiological and Environmental Sciences Laboratory (RESL) (IF-601), and EROB (IF-654) (one for the whole building, and one for just the data center). These meters were integrated into the existing Carrier i-Vue building control system for data compilation and trending. These three buildings currently have the highest probability of meeting the energy use requirements of the Guiding Principles.

There are 93 owned facilities at the INL desert site representing a total of $2,600,632 \mathrm{ft}^{2}$ or $47 \%$ of the total INL Site footprint that were selected for further evaluation toward the cost effectiveness of advanced metering for electricity. Twenty-five buildings are metered at MFC, three buildings are metered at CFA, and one building is metered at the ATR Complex. The meters at CFA (CF-1611, CF-1612, and CF-1618) and at the ATR Complex (TRA-1626) were installed during FY 2011 as part of the Office of Nuclear Energy (NE) funded Metering Project. Eight buildings at the ATR Complex are metered together as a process and are currently listed as INL's only Excluded Facilities for the energy efficiency goals. These 37 metered facilities represent $40 \%$ of the selected appropriate buildings for metering that are actually currently metered.

\subsubsection{Planned Actions}

The seven facilities that had new meters installed during FY 2011 will be monitored and the data compiled for input into the Environmental Protection Agency (EPA) Portfolio Manager online tool to determine a score for energy use. This score will then be used to validate the buildings energy performance for the Guiding Principles. 
As outlined in the INL Metering Plan, there are nine additional meter installation opportunities at IRC to obtain building level metering for the balance of the buildings at IRC. In addition, there are 12 Idaho Falls buildings that would benefit from advanced metering and will be targeted by the City of Idaho Falls advanced meter installation project. These 12 buildings are currently serviced by standard meters and the data is being compiled in the quarterly INL Energy Use Reports.

The City of Idaho Falls is planning to upgrade all of its electrical power meters to smart meter technology. Major INL Idaho Falls facilities will be upgraded as part of the city's initial upgrade project beginning in FY 2012. This upgrade will provide smart meters and a network to supply a central datacollection point to view and analyze the data, and provide demand management capabilities.

In addition to providing a means of trending and validating energy savings, metering also provides proactive space management opportunities. Building energy and water usage information assists with maintenance scheduling, enhanced resource utilization, and accurate space charge-back to building tenants. Advanced metering provides a method to encourage and validate employee behavior change, and provides a dependable tool for facility managers to tune building systems and controls.

Finally, as outlined in the INL Metering Plan, there are 55 additional facilities at the desert site that have been identified for meter installations to meet the goal of $90 \%$ of INL electric energy metered by the end of FY 2012. Of these 55 facilities, five are planned to meter in FY 2012 using a small portion of the Sustainability Program's Strategic Investment funding. These five facilities were identified as the best candidates to implement the Guiding Principles that are not targeted by the ESPC Project at CFA and ATR Complex. The next ESPC project has targeted 12 facilities that are the best candidates for implementation of the Guiding Principles. The remaining 38 facilities were evaluated by the Metering Plan spreadsheets provided by the Sustainability Performance Office and were found to not be cost effective to meter; however, they are included in the INL Metering Plan as acceptable alternatives for metering to meet the $90 \%$ goal. Additional funding will be needed to provide metering for these facilities, which are currently scheduled for potential installations in FY 2013.

\subsection{Cool Roofs}

\section{Cool roofs, unless uneconomical, for roof replacements unless project already has CD-2 approval. New roofs must have thermal resistance of at least $R-30$.}

INL initiated implementation of the National Nuclear Security Administration's Roof Asset Management Program (RAMP) in FY 2010. RAMP is a unique, corporate approach to management of roofs across the DOE laboratory complex. By treating roofs at multiple sites as an aggregate portfolio and earmarking a reliable funding stream, this program attracts the technical expertise of "best of class" national roofing consultants and contractors, achieves consistency in condition assessments, and provides economies of scale in roof repairs and replacements. The RAMP program directs resources to the most compelling roofing deficiencies of the complex, documents significant savings, and enhances the value added to the facilities portfolio through optimal repairs. Shared lessons learned have improved performance at all participating sites in safety, scheduling, and overhead reductions. Due to the effectiveness of this partnership between DOE-HQ, the DOE site offices, and the Management and Operating contractors, the program has renewed the contract with a nationally recognized integrating contractor for the remainder of the Facility Infrastructure Revitalization Program (FIRP) program. INL is a partner site with the RAMP program.

In addition to active participation with the RAMP program, INL has the unique status of having installed a cool roof on a National Historic Landmark facility, the Experimental Breeder Reactor (EBR)-1 museum. 


\subsubsection{Performance Status}

In FY 2011, INL replaced 19,933 $\mathrm{ft}^{2}$ of roofing on CFA-698 (Standards and Calibration Laboratory) and the MFC-717 (Modular Office Building) with new roofing on the RAMP program that meets the Secretary of Energy's requirements for "cool roofs" and eliminated over $\$ 400 \mathrm{~K}$ of deferred maintenance. Two additional "cool roofs" were installed on two sections of MFC-774 using the INL's normal roof replacement program.

ICP installed a cool roof over the basement of the TRA-604 modification in FY 2011. The roof area is $18,346 \mathrm{ft}^{2}$.

\subsubsection{Planned Actions}

INL will continue to use the DOE-NNSA RAMP program to install an additional 20,000 $\mathrm{ft}^{2}$ of roofing that meets the DOE "cool roof" requirement and will incorporate "cool roof" requirements into non-RAMP roof replacements as appropriate with the normal INL roof replacement and maintenance program.

In addition to the programmatic planned actions, INL will complete construction and occupy the new Energy Systems Laboratory (ESL) at the Idaho Falls Campus. In FY 2011, INL negotiated the installation of a cool roof on this $91,000 \mathrm{ft}^{2}$ facility at no additional cost. The total square footage of cool roof installed will exceed $25,000 \mathrm{ft}^{2}$.

No ICP planned actions for Cool Roof installations within the remaining duration of the current contract. After the ICP contract is complete, the buildings will be addressed on a case-by-case basis.

\subsection{Renewable Energy}

\section{5\% of annual electricity consumption from renewable sources by FY 2013 and thereafter (5\%} FY 2010-2012).

The INL Site is actively pursuing Renewable Energy Generation capability and is annually purchasing Renewable Energy Credits (RECs) in amounts as outlined in the Energy Policy Act of 2005.

The goal for onsite renewable energy generation and direct purchase of new renewable electricity may not be met due to the low cost of electricity from abundant older hydroelectric and coal sources. The payback for renewable energy projects is unlikely to be successful without supplemental funding to support such projects.

\subsubsection{Performance Status}

There is one solar transpired wall at the IRC Records Storage Facility. This wall preheats outside fresh air for the office area of this facility. Two other transpired solar walls were installed in FY 2010 as part of the MFC ESPC project. These solar walls provide renewable energy that avoids the use of conventionally generated electricity. Although solar walls avoid other energy use and are a renewable source, they do not contribute to meeting this goal.

INL continued to evaluate the feasibility of installing a 20-MW wind farm on the INL Site and completed the business case analyses at eight sites. The analysis confirmed that a wind farm project on the proposed scale is not currently economically feasible on the INL Site. Part of the evaluation included hosting the first INL sustainability summit with state, industry, and regulatory leaders. Over 50 people attended and presentations were made by DOE-ID, INL, U.S. Fish and Wildlife Services, Idaho Public Utilities Commission, Idaho Falls Power, Idaho Power, Center for Advanced Energy Studies (CAES), INL Research and Development (R\&D), and various private industries (wind, solar, biomass). Attendees included INL and DOE-ID staff, Bonneville Power Administration (BPA), utilities, and a representative

of the Governor's office. INL continues to evaluate alternative sites for a potential wind farm and collect 
suitable data based on private industry recommendations during this summit. However, the original plan and location were abandoned based on INL mission compatibility and costs.

As an interim compliance activity, the INL Site has procured a total of 16,900 MWh of RECs from the Western Area Power Administration (WAPA) at a total cost of \$14,365. This purchase represents $7.5 \%$ of the INL Site's electric usage in FY 2010 and is the purchase for FY 2011. The REC purchase for FY 2011 was distributed among all of the INL power users, including the Naval Reactors Facility (NRF), to both help shoulder the cost as well as enable them to claim a $7.5 \%$ renewable energy purchase.

\subsubsection{Planned Actions}

Low energy costs benefit the INL Site, allowing for increased strategic missions and facility enhancements. However, cost benefit analyses generally lead decision makers to place a lower priority on installation of renewable energy projects.

During ESPC contract negotiations, existing lease updates, and new lease negotiations, installation of renewable energy generation is considered and payback evaluated. The proposed ESPC may result in one or two small renewable energy generation projects (wind or solar), but is not identifying any projects that would cumulatively produce the electricity necessary to meet the goal of $7.5 \%$ of INL Site electric use. INL R\&D continues to investigate the potential installation of numerous renewable energy technologies, but INL will not invest limited funding into renewable projects that are not economically viable or mission compatible.

The INL Site could meet the onsite renewable energy generation goal if funding is secured to support renewable energy installation on the INL Site or if direct purchase of renewable energy becomes available from energy providers. However, if funding is not obtained, the goal will not be met.

The INL Site will continue to meet the minimum requirements of purchasing $7.5 \%$ of the electric energy usage in equivalent RECs. However, INL has committed to increase purchase of RECs starting in FY 2012 to $10 \%$ of the INL electric usage. Although the increase does not contribute to the GHG reduction goal, it does demonstrate INL's commitment to climate change adaptation and strategic leadership. The calculation method is based on the following: assume 10\% of the previous year's purchased electricity total will be purchased as RECs in the current year (i.e., FY 2012 REC purchase is $10 \%$ of FY 2011 total purchased electricity). All INL Site contractors will share in this purchase and will be assigned the REC benefits according to their annual electric use.

\subsection{Fleet Alternative Fuels}

\section{0\% annual increase in fleet alternative fuel consumption by FY 2015 relative to an FY 2005 baseline.}

The INL Site is developing diversified strategies for increasing alternative fuel consumption and reducing carbon emissions associated with light and heavy-duty vehicles. One of the DOE Order 436.1 transportation fuels goal is to increase the use of alternative fuels by $10 \%$ annually, as compared to the FY 2005 usage baseline. There are many opportunities to affect DOE's alternative fuel consumption by implementing fuel switching activities at INL.

\subsubsection{Performance Status}

In FY 2011 the INL Site used 236,889 gasoline gallon equivalents of alternative fuels. This represents an increase of $210 \%$ over the FY 2005 use, and a 39\% increase over FY 2010. These usages are a compilation of all INL Site contractors and the total of each of the various alternative fuels as reported into the Fleet Automotive Statistical Tool (FAST) database. These fuel use data indicate that the INL Site is exceeding the alternative fuel use goal and expects to continue this performance through FY 2015. 
The INL Site is exceeding the alternative fuel increase goals through actively pursuing Ethanol (E-85) fuel usage and by using biodiesel blends. These increases are facilitated by increasing the availability of E-85 and mandating its use while researching and implementing the use of biodiesel blends in the INL bus fleet throughout the year and across varied climate conditions.

\section{Completed activities include:}

- Increased the availability of alternative fuel by converting petroleum tanks to alternative fuel tanks and by encouraging the use of alternative fuel by all users of flex fuel vehicles.

- Updated the existing fueling infrastructure and provided additional alternative fuel locations to allow for improved fuel use tracking and control. Used a new technology, Radio Frequency Identification (RFID) fuel rings, also called "ring technology," making it easier to fuel INL vehicles by automatically capturing mileage and other data that employees once had to enter manually.

- Partnered with a local fuel distributor to make E-85 commercially available to east Idaho.

- Acquired 101 light-duty vehicles in FY 2011, 47 are flex-fuel (46.5\%), 46 are hybrid (45.5\%), and 8 are gasoline (8\%). Of the 101 acquired, $92 \%$ are either AFVs or hybrid vehicles.

- Reported to flex fuel vehicle owners (quarterly) their percentage of E-85 usage compared to unleaded usage and encouraged the use of the appropriate flex fuel. This method of encouraging self-governing through information has lead to increases in E-85 fuel use.

\section{Ongoing activities include:}

- Selected by General Services Administration (GSA) to receive three American Recovery and Reinvestment Act (ARRA) funded Parallel Hybrid drive shuttle buses to replace three 24-year-old buses. These new buses reduce petroleum use through greater efficiency and use biodiesel. In FY 2011, the new buses were used on lightly loaded commuter routes and for shuttle and tour service.

- Researched methods to use B20 in the bus fleet year around.

- Continued efforts to right size the fleet with more flex-fuel vehicles capable of using E-85.

- DOE-ID and INL began collaborating with the Yellowstone-Teton Clean Energy Coalition (local area Clean Cities program) to encourage and cooperate with local fueling stations and vendors to provide alternative transportation and fueling stations in the area.

The AMWTP currently operates 91 passenger carrying light use vehicles for transportation of personnel and goods to the desert site. The fleet consists of minivans capable of transporting up to six individuals. This small fleet averages $3 \mathrm{M}$ miles a year transporting approximately 600 personnel to and from car-pool locations in local community areas surrounding the INL Site.

Each vehicle in the AMWTP fleet is an AFV, and capable of using unleaded regular or E-85 as a fuel. In FY 2010, the AMWTP partnered with the local fuel distributer to furnish E-85 fuel at a single location in Idaho Falls. Use of this in-town fueling infrastructure continued in FY 2011. Employee commute vanpools based in Idaho Falls were requested by AMWTP management to use the E-85 fuel. These actions resulted in approximately 50\% of total fleet using E-85. The AMWTP was able to meet the $10 \%$ annual increase in fleet alternative fuel consumption by FY 2015 goal.

\subsubsection{Planned Actions}

Additional increases in the use of alternative fuels will be obtained through numerous INL Site identified projects and activities that include:

- Replace the INL bus fleet with 50 new motor coaches that run on B20 and have improved fuel mileage by up to $50 \%$ (3 $\mathrm{mph}$ to $6 \mathrm{mph}$ ).

- Continue researching the potential conversion of the INL bus fleet to alternative fuel types. 
- Continue to track and trend reliability, fuel usage, and optimize performance of new bio-diesel compatible buses while evaluating future purchases.

- Continue to encourage and establish process to stimulate the use of E-85 in flex-fuel vehicles at the end user level. This includes individual goal setting at an organization level and holding individuals accountable for non E-85 fuel purchases.

- Replace fleet heavy trucks and equipment with new equipment that will run on B20.

- Increase the use of Alternative Fuels by converting the boilers at CFA to run on biodiesel.

\subsection{Fleet Petroleum Fuels}

\section{2\% annual reduction in fleet petroleum consumption by FY 2020 relative to a FY 2005 baseline.}

The INL Site is developing diversified strategies for reducing fossil fuel use and carbon emissions associated with light and heavy-duty vehicles. One of the DOE Order 436.1 transportation fuel goals is to reduce petroleum fuels by $2 \%$ annually through FY 2020 (30\% total reduction), as compared to the FY 2005 usage baseline. There are many opportunities to affect DOE's petroleum fuel usage by implementing fuel reduction and fuel switching activities at INL.

\subsubsection{Performance Status}

In FY 2011, the INL Site used 862,527 gasoline gallons equivalent, an 8.1\% reduction from FY 2005. This usage is a compilation of all INL Site contractors and the total of gasoline and diesel fuels as reported into the FAST database. INL used 623,934 gal of petroleum fuels, a 30\% decrease over the FY 2005 and a 23\% decrease from FY 2010.

Completed activities include:

- Increased overall bus efficiencies by implementing express routes and eliminating underutilized routes. This was in conjunction with continued efforts in right sizing the fleet with more flex-fuel vehicles and hybrids.

- Incorporated the Park and Ride concept to reduce bus fuel usage, and developed additional Park and Ride lots for employees at outlying locations.

- Used innovative technology to track and reduce fuel usage such as Global Positioning System (GPS), Radio Frequency Identification (RFID) fuel rings, and data logger technology to monitor engine performance and driver habits.

Ongoing activities include:

- Continue research methods to use biodiesel blends in the bus fleet year around, reducing the need for $100 \%$ diesel.

- Continue the Reduce Idle Campaign that is saving fuel by better managing idling times. Results are positive as this campaign is saving 1,400 gal of fuel per month.

- Continued efforts to right size the fleet with more fuel efficient vehicles.

As the AMWTP has operated its van-pool commuter fleet to meet alternative fuel use goals, it has also contributed to a corresponding reduction in petroleum fuel use. 


\subsubsection{Planned Actions}

Additional reductions in petroleum-based transportation fuels will be obtained through numerous INL Site identified projects and activities that include:

- Replace over 55\% of the INL bus fleet with 50 new motor coaches that run on B20 and improve fuel mileage by $50 \%$ (3 mpg to $6 \mathrm{mpg}$ ).

- Add one additional Park and Ride location to further reduce employee commute and bus fleet fuel usage.

- As the AMWTP comes to a close, the INL Site anticipates a reduction in petroleum usage. Additionally, several pieces of heavy equipment will be consolidated further to reduce vehicle inventory and fuel usage.

- Evaluate technology that will allow INL to operate the bus fleet on "mixed" fuel, which is a combination of compressed natural gas $(\mathrm{CNG})$ and biodiesel. This may allow INL to reduce fuel usage by up to $30 \%$.

- The INL Site commitment to reduce vehicles 35\% by FY 2015 will also contribute to this reduction.

\section{$1.8 \quad$ Fleet Vehicle Purchases}

75\% of light-duty vehicle purchases must consist of alternative fuel vehicles (AFV) by FY 2000 and thereafter.

INL procures light-duty fleet vehicles almost exclusively through the GSA vehicle-leasing program. Maximizing the use of this GSA program is at the forefront of INL plans to achieve this goal. A rotation schedule based on vehicle age and mileage determines when vehicles are returned to GSA. When currently allocated vehicles are due for replacement, the old vehicle is replaced with an AFV or hybrid vehicle from GSA. There are currently very few exceptions for receiving conventional vehicles. Examples include some emergency response vehicles and heavy-duty full-size pickups. However, DOEHQ has directed that hybrid vehicles (which are not AFV vehicles at this time) be procured when available. This greatly impacts the $75 \%$ AFV target.

\subsubsection{Performance Status}

INL light-duty fleet is comprised of 396 vehicles of which 71\% are AFV, 224 are E-85, and 58 are gas/electric hybrids. The INL Site acquired 101 light-duty vehicles in FY 2011, 47 are flex-fuel (46.5\%), 46 are hybrid (45.5\%), and 8 are gasoline (8\%). Of the 101 acquired, 92\% are either AFVs or hybrid vehicles.

\subsubsection{Planned Actions}

The INL Site will continue to monitor and evaluate vehicle utilization. If an AFV can perform adequately relative to a non-AFV, a substitution will be made. INL is also evaluating future technologies to improve the fleet composition. Items that are currently being evaluated include:

- Hybrid capabilities for light-duty full-size vehicles, including $3 / 4$ and 1-ton pickups

- All electric vehicles for building to building transportation

- Retrofit current fleet with dual-fuel technology. 


\title{
1.9 Fleet Inventory Sizing
}

\author{
Reduce fleet inventory by 35\% within the next 3 years (end of FY 2014) relative to a FY 2005 \\ baseline.
}

\subsubsection{Performance Status}

The INL Site met the interim goal of a 15\% fleet reduction in FY 2011.

INL performed a complete 2-year utilization study in August of 2010 to begin a Vehicle Allocation Methodology (VAM). Many government agencies are now requiring a VAM including GSA. The purpose of a VAM is to provide Fleet Managers with standard, decision-making criteria and data to determine the optimal vehicle allocation for their fleets. More precisely, it is a tool for establishing and controlling fleet size and composition, more succinctly and popularly termed "right-sizing." From the standpoint of the Office of Management and Budget (OMB), a VAM documents the basis for fleet size and, consequently, fleet-related budgets. In addition, implementation of a VAM can help user-groups to acquire the appropriate number and types of vehicles and equipment according to a clearly defined set of policies and procedures.

INL is making great strides in reducing the size of the fleet while ensuring the capability of meeting INL missions. Since FY 2010, INL has reduced the heavy equipment pool by 38 pieces of equipment. In FY 2011, the following were incorporated into INL fleet operations, reducing fleet numbers without losing support capabilities.

- INL modified three heavy-duty trucks to carry multiple beds. A heavy-duty truck is typically a singlepurpose truck (i.e., a dump truck can only be a dump truck). These trucks now use a J-Hook lift and removable beds to accomplish multiple functions. INL maintains a flat rack bed, water truck bed, dump bed, panel truck bed, garbage container bed, and sander bed that can be used on any of these three trucks.

- INL continued working with GSA on replacing the aging and fuel inefficient bus fleet. The current fleet size is 103 buses. Converting to GSA leasing will reduce the total number of buses by 13, maintaining a core bus fleet of approximately 90 buses. This reduction is possible through greater seating capacity of the new buses, each capable of seating 55 passengers (older coaches seat 44 passengers). A newer fleet will require fewer spare coaches due to mechanical unreliability.

- INL is consolidating equipment and prepositioning a small equipment pool at MFC. There is currently one large equipment pool located at CFA. Historically, when a piece of equipment was needed at another location, a duplicate piece of equipment was often purchased. Consolidating the equipment pool and maintaining a satellite area will allow the overall equipment pool to decrease in size and increase equipment utilization.

\subsubsection{Planned Actions}

The INL Site and DOE-ID have committed to meet the 35\% reduction goal by FY 2015.

INL continues to evaluate fleet inventory and is focusing on two key usage areas: light-duty fleet and heavy equipment. AMWTP and ICP continue to evaluate vehicle as cleanup missions are complete or scope reduced.

In FY 2012, the light-duty fleet will be reduced through the following actions:

- A Key Valet system will be established at WCB. The goal of this system will be to reduce the number of permanently assigned vehicles and transition to an as-needed daily rental system. The unmanned electronic key box will dispatch the keys and collect vehicle information such as miles driven and duration of dispatch. 
- Assigned permanent vehicle reduction effort. Justification for light-duty vehicle permanent assignment will be handled through a rigorous procurement process in combination with the fleet coordinator. A determination of need will be based on established criteria and vehicle availability.

In FY 2012, the heavy equipment pool will be reduced through the following actions:

- Eliminate duplicate pieces of heavy equipment with low utilization. Historically, facility and research projects required specific heavy equipment a few times over a long duration. Instead of placing the equipment back into the equipment pool for others to use, the equipment was kept at the same facility location and then used later as needed. As contracts expire, this equipment will be consolidated into a central motor pool to reduce duplicate equipment and increase equipment utilization. Not only does this reduce the size of the equipment pool it also reduces maintenance costs.

- Formation of a fleet equipment users group to reduce the equipment pool without sacrificing critical support. The group will consist of the key users of heavy equipment at all Site facilities and procurement. The goal of this group will be to ensure any reduction made will not have negative consequences to INL. 


\section{SCOPE 3 GREENHOUSE GASES \\ 2.1 Scope 3 Greenhouse Gas Reduction}

\section{3\% Scope 3 GHG reduction by FY 2020 from a FY 2008 baseline.}

Executive Order 13514 mandates that agencies develop specific GHG reductions. DOE has set a reduction target of 13\% for Scope 3 greenhouse gases. The EO sets 2008 as the baseline year against which reductions will be measured.

The INL Site reported Scope 3 GHG emissions for the baseline year, FY 2008, and annually thereafter. Using the Global Reporting Initiative standards, Scope 3 is defined as:

- Indirect or shared emissions generated by outsourced activities that benefit the INL Site (occur outside the INL Site's organizational boundaries, but are a consequence of the INL Site's activities).

This can include a large number of activities, so the INL Site focused on transmission and distribution losses, employee commuting, employee travel, contracted waste disposal and contracted wastewater treatment since these categories were identified in the Technical Support Document for required reporting. Other activities that could be included in Scope 3 include the embodied emissions of purchased materials.

The INL Site contractors' EMS provides the framework and process for evaluating and monitoring Scopes 1, 2, and 3 GHG emissions and related reduction activities. On an annual basis, appropriate sustainability targets are developed and monitored through the EMS to support the overall reduction in GHG emissions.

As the Environmental Management missions end at various site locations, overall Scope 3 emissions are expected to decrease. Between FY 2011 and FY 2017, employees traveling to and from the Site location may be reduced by as many as 2,000 when subcontractors are included. Removing vehicles directly impacts Scope 1 and Scope 3 emissions.

The challenge is to minimize the impact of operations while increasing the growth of the Laboratory. INL is integrating environmental performance improvement in the areas that matter most to its stakeholders and the Laboratory, including minimizing the environmental footprint, taking a progressive approach to climate change, and championing energy conservation.

\subsubsection{Performance Status}

Based on data entered into the CEDR for FY 2011, the INL Site has reduced Scope 3 greenhouse gas emissions 23.3\%. (FY 2008 - 37,057 mT CO2e and FY 2011 - 28,460 mT CO2e).

INL completed an update to the FY 2008 GHG baseline based on updated guidance. Minimal changes occurred as a result of this update. Additionally, INL completed comprehensive inventories for FY 2009 and FY 2010.

As found in Table 4, each Scope 3 category is listed for FY 2008 and FY 2011 and the calculated emission needed for each by FY 2020. 
Table 4. INL Site Scope 3 GHG calculation results for FY 2008 and FY11, and the FY 2020 Goal, by emissions category.

\begin{tabular}{|c|c|c|c|c|}
\hline Scope & Emissions Category & $\begin{array}{l}\text { FY } 2008 \text { Baseline } \\
\left(\mathrm{MT} \mathrm{CO}_{2} \mathrm{e}\right)\end{array}$ & $\begin{array}{l}\text { FY } 2011 \text { Actual } \\
\left(\mathrm{MT} \mathrm{CO}_{2} \mathrm{e}\right)\end{array}$ & $\begin{array}{l}\text { FY } 2020 \\
\text { Reduction Goal } \\
\left(\mathrm{MT} \mathrm{CO}_{2} \mathrm{e}\right) \\
\end{array}$ \\
\hline \multirow[t]{7}{*}{3} & $\begin{array}{l}\text { Electrical Transmission \& } \\
\text { Distribution Losses (Outside } \\
\text { INL's Operational Controls) }\end{array}$ & $6,252.4$ & $5,661.0$ & $5,439.6$ \\
\hline & Employee Commuting & $20,525.0$ & $14,791.8$ & $17,856.8$ \\
\hline & Business Air Travel & 8198.7 & 6200.0 & 7132.9 \\
\hline & $\begin{array}{l}\text { Business Ground Travel: } \\
\text { Rental Vehicles }\end{array}$ & 1469.0 & 923.0 & 1278.0 \\
\hline & $\begin{array}{l}\text { Contracted Mixed Solid } \\
\text { Waste Disposal }\end{array}$ & 557.8 & 870.0 & 485.2 \\
\hline & $\begin{array}{l}\text { Contracted Wastewater } \\
\text { Treatment }\end{array}$ & 55.0 & 14.5 & 47.7 \\
\hline & Scope 3 TOTAL & $37,057.9$ & $28,460.4$ & $32,240.4$ \\
\hline
\end{tabular}

Similar to Scopes 1 and 2 GHG emissions described above, one of the most significant factors that influence INL's Scope 3 GHG emissions is the large land area that requires long commutes (approximately 50 miles, one way). Transportation fuel was, in turn, the largest source of GHG emissions within Scope 3. Another source with high emissions was business air travel. Sources with low emissions were contracted waste disposal, contracted wastewater treatment, and business ground travel (rental and personal vehicles).

INL continues to reduce GHGs by transporting employees with a modernized transportation system, taking nearly 2,000 cars per day off the road. By streamlining the INL mass transit system that provides safe, efficient, and sustainable transportation to work for INL employees throughout the eastern Idaho region, INL encourages travel behavior changes to reduce carbon emissions and fossil fuel consumption, increased highway safety, and in doing so, INL models future trends in mass transit to local governments across the region. Other actions include instituting a park and ride system, relocating employees to town offices, use of E-85 and biodiesel fuels, and use of modern buses, vans, and light-duty vehicles to reduce carbon emissions.

\subsubsection{Planned Actions}

The INL Site will continue to implement projects that reduce employee commute, employee travel, waste disposal, and minimize electric usage to reduce Transmission and Distribution losses. Corresponding Scope 3 emission reductions will occur. Knowing the target emission for each GHG category as found in the INL GHG Reduction Strategy, helps prioritize and plan projects accordingly.

Employee Commute Reduction tactics include:

- Change commute by increasing carpools, change personal car use to INL buses

- $\quad$ Parking management through parking pricing (e.g., begin charging, give discount for rideshare parking); preferential parking (e.g., designated carpool and vanpool spaces); parking supply reduction.

- Move employee work locations from Site to town when reasonable.

- Increase INL Bus ridership for Site employees by 5\%. 
- Increase telecommuting.

- Telework centers.

- Facility enhancements.

- $\quad$ Secure bike storage or bike racks, shower facilities, and lockers.

- Use alternative fueled vehicles on business travel.

- Promote use of emission free transportation source such as walking and biking.

- Subsidies:

- Vanpool subsidies on a limited or continual basis.

- Empty seat subsidy - to limit the amount start-up riders have to pay until new riders join.

- Bike maintenance subsidy.

Employee Travel Reduction strategies:

- Use video and web conferencing to hold virtual meetings and avoid travel when possible.

- Increase rentals of hybrid and alternative fueled vehicles over traditional options on business travel.

- Reduce air travel, particularly short range (<300 miles) air travel, except where necessary for mission accomplishment.

- Reduce car rentals by promoting carpooling at conferences and other meetings on business travel.

- Research establishing a government rate for plug-in hybrid electric vehicle (PHEV) and hybrid electric vehicle (HEV) rentals while on business travel.

- Encourage the use of public or group transportation modes at destination cities. 


\section{HIGH PERFORMANCE SUSTAINABLE BUILDINGS (HPSB) 3.1 HPSB Existing Buildings}

$15 \%$ of existing buildings greater than 5,000 gross square feet (gsf) to be compliant with the five Guiding Principles (GPS) of High Performance Sustainable Buildings (HPSB) by FY 2015.

There are 27 Guiding Principles in five categories. To achieve compliance with the Guiding Principles, all 27 must be met.

As indicated in the Facilities Information Management System (FIMS) database, the INL Site has 170 buildings that are appropriate to consider for audits and upgrades to implement the Guiding Principles. Fifteen percent of these buildings calculates to a minimum of 26 buildings that must meet the Guiding Principles by FY 2015. The Existing Buildings worksheet of the CEDR contains 23 buildings identified as having the highest probability of meeting the Guiding Principles. These buildings are either currently metered or have been targeted for metering in FY 2012. Of these 23 buildings, one is LEED ${ }^{\mathrm{TM}}$ Certified, one is $\mathrm{LEED}^{\mathrm{TM}}$ Gold certified, and one is pending LEED ${ }^{\mathrm{TM}}$ Gold certification. The remaining 20 buildings will be targeted for the Guiding Principles compliance path.

\subsubsection{Performance Status}

The Technical Support Building (TRA-1608) was LEED ${ }^{\mathrm{TM}}$ certified in November 2010. The LEED ${ }^{\mathrm{TM}}$ design package was also submitted for the new Radiological Environmental Sciences laboratory (IF-683) during FY 2011.

Metering was installed on seven facilities (three in town, three at CFA, and one at ATR Complex) so that electrical data can be compiled for entry into Portfolio Manager. Energy and water reduction projects were developed in FY 2011 for IF-601, IF-602, IF-616, and IF-654 to further enhance implementation of the Guiding Principles in these facilities.

INL documented compliance with eight of the 27 Guiding Principles.

The INL Site performed assessments on over $90 \%$ of the buildings eligible for Guiding Principle certification, resulting in the DOE HPSB scorecard going from red to green in two of the four measured categories for NE.

\subsubsection{Planned Actions}

INL Site facilities planned to meet the Guiding Principles do not include buildings owned by EM. Since the EM mission at the INL Site is to reduce footprint and complete the cleanup, the existing building life is either to short or to uncertain to invest in upgrades. This presents a challenge because the INL Site as a whole must meet the $15 \%$ goal (26 buildings) as noted above. While only 23 buildings are listed in the CEDR, INL has further evaluated facilities and identified 27 INL facilities (1 more than the required 26) that have the highest probability of fully implementing the Guiding Principles. However, this is 11 above the original INL target of 16 facilities (15\% of the INL total) and is unlikely to occur by FY 2015 without additional project funding. All 27 facilities are listed in Table 5. This table includes information on metering and the year each building is expected to meet the Guiding Principles based on preliminary engineering evaluations. However, each of the additional 11 facilities INL now has responsibility for will be fully evaluated in FY 2012 to determine if the Guiding Principles can be fully implemented by FY 2015. This table will be used as the work plan for prioritizing and manage the certification process for these identified buildings. 
INL will install up to nine energy and water reduction projects in WCB, EROB, and ROB. These projects were developed during FY 2011 for implementation with INL Strategic Investment funding in FY 2012. These following projects are expected to help these buildings achieve an acceptable Energy Star Building score of 75 or higher for input into Portfolio Manager:

1. WCB Chiller Replacements

2. EROB $\mathrm{CO}_{2}$ Controls

3. WCB Water Fixture Replacements

4. IRC (IF-602) Water Fixture Replacements

5. WCB Lighting Fixtures

6. WCB Lighting Controls

7. WCB Exterior Lighting Fixtures

8. ROB (IF-601) Exterior Lighting Fixtures

9. IRC (IF-603) Motor/Controls.

In FY 2012, INL will continue to develop additional projects for FY 2013 funding that will upgrade the selected facilities in Table 5 to meet the Guiding Principles by the planned date. In addition, CF-1611, CF-1612, CF-1618, and TRA-628 will be targeted by ESPC Project 3 for Energy Conservation Measures that will help these four facilities meet the Guiding Principles.

The remaining 17 procedure oriented Guiding Principles will be documented and both IF-663 and IF-654 are planned for Guiding Principle compliance.

Table 5. Buildings planned to meet Guiding Principles.

\begin{tabular}{|l|c|c|c|c|l||}
\hline \multicolumn{1}{|c|}{ Building } & Metered & iVue & $\begin{array}{c}\text { Water } \\
\text { Metered }\end{array}$ & $\begin{array}{c}\text { GP } \\
\text { Compliant }\end{array}$ & \multicolumn{1}{|c||}{ Comments } \\
\hline REL & 2014 & 2014 & 2014 & 2015 & LEED $^{\text {TM }}$ Gold in FY 2015 \\
\hline ESL & 2012 & 2012 & 2012 & 2013 & LEED $^{\text {TM }}$ Gold in FY 2013 \\
\hline MFC TSB & 2013 & 2013 & 2013 & 2014 & LEED $^{\text {TM }}$ Gold in FY 2014 \\
\hline IMCL & 2012 & 2012 & 2012 & 2012 & LEED $^{\text {TM }}$ Gold in FY 2012 \\
\hline IF-665 (CAES) & Yes & No & Yes & Yes & LEED $^{\text {TM }}$ Gold \\
\hline IF-683 (RESL) & 2012 & 2012 & No & 2012 & LEED $^{\text {TM }}$ Gold in FY 2012 \\
\hline $\begin{array}{l}\text { TRA-1608 } \\
\text { (TSB) }\end{array}$ & No & No & No & Yes & LEED $^{\text {TM }}$ Certified \\
\hline $\begin{array}{l}\text { TRA-1626 } \\
\text { (TTAF) }\end{array}$ & Yes & Yes & No & 2013 & LEED $^{\text {TM }}$ Certified Except for Energy \\
\hline IF-601 & Yes & Yes & No & 2013 & \\
\hline IF-602 & Yes & 2012 & No & 2014 & \\
\hline IF-616 & Yes & 2012 & Yes & 2014 & \\
\hline IF-654 & Yes & Yes & Yes & 2012 & GP Compliant in FY 2012 \\
\hline IF-663 & Yes & Yes & No & 2012 & GP Compliant in FY 2012 \\
\hline IF-680 & Yes & 2012 & 2013 & 2014 & Water Meter by City of Idaho Falls \\
\hline IF-684 & Yes & 2012 & 2013 & 2014 & Water Meter by City of Idaho Falls \\
\hline CF-1611 & Yes & Yes & No & 2013 & \\
\hline CF-1612 & Yes & Yes & No & 2013 & \\
\hline CF-1618 & Yes & No & 2013 & \\
\hline \hline
\end{tabular}


Table 5. (continued).

\begin{tabular}{|l|c|c|c|c|l||}
\hline \multicolumn{1}{|c|}{ Building } & Metered & iVue & $\begin{array}{c}\text { Water } \\
\text { Metered }\end{array}$ & $\begin{array}{c}\text { GP } \\
\text { Compliant }\end{array}$ & \multicolumn{1}{|||}{ Comments } \\
\hline CF-609 & 2012 & 2012 & No & 2015 & \\
\hline CF-621 & 2012 & 2012 & No & 2015 & \\
\hline CF-623 & 2012 & 2012 & No & 2015 & \\
\hline CF-696 & 2012 & 2012 & No & 2015 & \\
\hline CF-698 & 2012 & 2012 & No & 2015 & \\
\hline MFC-710 & Yes & 2012 & No & 2014 & $\begin{array}{l}\text { Need to Access ESPC Installed } \\
\text { Meter }\end{array}$ \\
\hline MFC-725 & Yes & 2012 & No & 2014 & $\begin{array}{l}\text { Need to Access ESPC Installed } \\
\text { Meter }\end{array}$ \\
\hline MFC-782 & Yes & 2012 & No & 2014 & $\begin{array}{l}\text { Need to Access ESPC Installed } \\
\text { Meter }\end{array}$ \\
\hline TRA-628 & 2012 & 2012 & No & 2014 & \\
\hline
\end{tabular}

\subsection{HPSB New Construction}

All new construction, major renovations, and alterations of buildings greater than 5,000 GSF must comply with the GPs and, where the work exceeds $\$ 5 M$, each are $L E E D^{T M}$ - NC Gold certification or equivalent.

The INL Site is implementing High Performance Sustainable practices and design specifications in new building design and construction by introducing High Performance Sustainable design criteria at conceptual design and following though during design and construction by using LEED $^{\mathrm{TM}}$ construction concepts and the Guiding Principles for High Performance Sustainable Buildings.

The INL Site also constructs buildings that are very mission specific and are not readily compatible with LEED ${ }^{\mathrm{TM}}$ or with the Guiding Principles. One new such facility is described as follows:

"INTEC's new Integrated Waste Treatment Unit (IWTU) is currently anticipated to have construction completed in FY 2012. This will be a large energy intensive facility with an estimated 3-year life. Due to the mission of this facility and its energy use characteristics, it is being planned for exclusion using Part $G$ of the Excluded Buildings Self

Certification. The internal process at this facility will consume most of the metered energy."

The IWTU was also at CD-2 before the LEED ${ }^{\mathrm{TM}}$ Gold requirement was implemented.

INL new construction includes DOE-owned and privately leased facilities. All existing leased facilities are privately owned. INL has no GSA leased facilities.

\subsubsection{Performance Status}

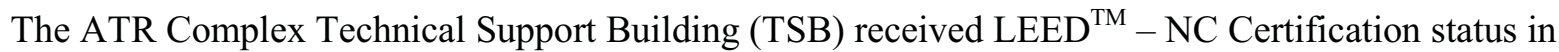
November 2010 from the U.S. Green Building Council.

Construction of the new RESL was completed in FY 2011 and LEED ${ }^{\mathrm{TM}}$-NC Gold certification is expected in FY 2012.

Construction was started on the new ESL, planed for DOE-ID lease, is expected to be finished by the end of FY 2012. LEED ${ }^{\mathrm{TM}}$ - NC Gold certification is planned for this facility and is expected to be certified in FY 2013. 


\subsubsection{Planned Actions}

In addition to the ESL described above, three other new buildings that are currently planned for LEED $^{\mathrm{TM}}$ Gold certification.

1. Research and Education Facility - 148,000 $\mathrm{ft}^{2}$ - Complete in FY 2013 (leased)

2. Irradiated Materials Characterization Lab - 12,000 ft ${ }^{2}$ - Complete in FY 2013 (owned)

3. MFC Technical Support Building - 17,000 ft² - Complete in FY 2014 (owned).

Neither ICP nor AMWTP are projecting any new building starts within the remaining duration of their current contracts. 


\section{WATER USE GOALS \\ 4.1 Water Use Reductions}

\section{$26 \%$ water intensity reduction by FY 2020 from a FY 2007 baseline}

The INL Site's goal for water usage is a 16\% reduction of usage intensity by FY 2015, or 2\% each year, as compared to the FY 2007 Water Usage Intensity Baseline measured in gal $/ \mathrm{ft}^{2}$.

Due to the nature of the various INL Site missions, many of the operations can be cyclical and result in varying usages of water throughout the year and from year to year. In addition, as facilities are removed and processes are shut down, the lower square footage can actually result in an increase in water use intensity even as overall water usage is reduced.

The water intensity reduction goal will be very difficult for the INL Site to accomplish. Long payback calculations based on inexpensive water and electric rates make water saving projects unattractive. Completion of the identified ESPC projects is anticipated to contribute approximately $7.5 \%$ towards the $16 \%$ goal. However, water usage is so dependent upon process usage and unplanned events such as the FY 2010 wildfires and ARRA-funded additional D\&D work, that the remaining $8.5 \%$ may be very difficult to obtain.

\subsubsection{Performance Status}

As per the water reduction goals found in DOE 436.1, the INL Site should be at an $8 \%$ water intensity reduction at the end of FY 2011 when compared to the FY 2007 Reportable Water Usage Baseline. The INL Site used a total of $898.7 \mathrm{M}$ gal of water in FY 2011, resulting in a water usage intensity of $166.8 \mathrm{gal} / \mathrm{ft}^{2}$, a decrease of $4 \%$ over the FY 2007 baseline $\left(173.9 \mathrm{gal} / \mathrm{ft}^{2}\right)$. However, as demonstrated through water use and building square footage data entered into the CEDR, the INL Site total water used has decreased from 1,050.9 M gal in FY 2007 to $898.7 \mathrm{M}$ gal in FY 2010, for a total water used reduction of $14.5 \%$.The INL Site 6,043,042 $\mathrm{ft}^{2}$ to 5,384,917 $\mathrm{ft}^{2}$, a reduction of $11 \%$ since FY 2007.

INL installed one meter at the INL Administration Building (IF-606) at a total cost of $\$ 2 \mathrm{~K}$. The City of Idaho Falls now charges INL an actual usage rather than a monthly flat fee. The payback was less than 6 months for this project. Additional projects of this type are possible and support meeting the reduction goal.

INL partnered with industrial water system experts from the Pacific Northwest National Laboratory (PNNL) to evaluate the water systems primarily at the ATR Complex. This evaluation identified several areas of significant water use that may be addressed through system modifications. The final report is due back to INL in mid-FY 2012. This report will be used for project development for FY 2013 Strategic Investment projects.

INL installed xeriscaping at one of the University Boulevard buildings in Idaho Falls.

INL completed implementation of the MFC ESPC project during FY 2011, which has eliminated the leaking condensate lines. Water reporting from FY 2011 indicates that water usage at MFC is down $2.3 \mathrm{M}$ gal as compared to FY 2010.

ICP completed the INTEC water supply system pump downsizing replacement project in FY 2010. This project has shown significant water savings for ICP during FY 2011. ICP also completed the deactivation, decommissioning, and demolition of the INTEC Analytical Laboratory facilities during FY 2011, which resulted in an additional $50 \mathrm{M}$ gal of annual water savings. 


\subsubsection{Planned Actions}

Other projects that will continue to contribute to water use reductions for the INL Site include several ongoing tasks:

- Leak analyses will continue at all areas of the Site.

- Strategic Investment projects for FY 2012 will replace antiquated plumbing fixtures at the WCB and IRC Office Building.

- INL will continue purchasing Environmental Protection Agency WaterSense or other water efficient products, which will be documented by Sustainable Procurement processes.

- The ESPC project planned for the ATR Complex, SMC, and CFA will eliminate once-through HVAC cooling water, increase efficiency through fixture replacements, locate and repair leaking water lines, and possibly reduce industrial water use at the ATR Complex.

- The new ESL and Research and Education Laboratory (REL) facilities in Idaho Falls are scheduled to be occupied in 2012 and 2014, respectively. These LEED $^{\mathrm{TM}}$ Gold facilities will be lower water users, incorporate xeriscaping concepts, and add over $239,000 \mathrm{ft}^{2}$ of space in the water intensity calculation.

- EM missions, as noted in the CEDR, will contribute to water reductions as facility missions are complete. These include the AMWTP complex of facilities being cold, dark, and dry, ceasing operation of the INTEC Liquid Waste Management System, and New Waste Calcine Facility shutdown.

Based on the previous cost of the MFC ESPC that resulted in a 5\% water reduction and the proposed ESPC at the ATR Complex and CFA, additional water reduction implementation at the INL Site could cost between $\$ 40 \mathrm{M}$ and $\$ 50 \mathrm{M}$. Projects include:

- Replace all high water use faucets, toilets, showerheads, and urinals across the INL Site.

- Upgrade ATR cooling tower.

- Detect and repair underground leaks.

- Repipe chiller water disposal paths.

- Reduce ATR Complex sewage lagoon size.

- Replace all inefficient domestic hot water heaters across the INL Site.

\subsection{ILA Water Use Reductions}

20\% water consumption reduction of industrial, landscaping, and agricultural (ILA) water by FY 2020 from a FY 2010 baseline.

ILA water is not applicable to the INL Site. All water obtained by the INL Site is obtained from the Snake River Plain Aquifer and is potable. The INL Site does not have access to any non-potable water supplies.

\subsubsection{Performance Status}

N/A.

\subsubsection{Planned Actions}

N/A. 


\section{WASTE MINIMIZATION \\ 5.1 Landfill Waste Diversion}

\section{Divert at least $50 \%$ of non-hazardous solid waste, excluding construction and demolition debris, by FY 2015.}

The INL Site Pollution Prevention Plan, DOE/ID-10333, describes the pollution prevention practices pursued at the INL Site. INL expanded the co-mingled recycling and paper shredding programs to the desert site facilities (CFA, MFC, and ATR Complex) during late FY 2010 and continued through FY 2011. INL is also working with INL Site contractors to expand co-mingled recycling at other site facilities. All INL employees are capable of participating in the co-mingled recycling program that allows employees to place a variety of recyclable materials into one collection bin. ICP also has co-mingled recycling at town facilities and paper recycling at the desert site facilities. With the exception of SMC, all town and desert site employees have the option to participate in the paper shredding recycling program, which includes regular office paper and controlled unclassified information (CUI) materials for shredding. In FY 2011, INL facilities recycled 216,831 lb of co-mingled materials and 441,760 lb of office paper and cardboard. With the participation of the Site facilities, the recycled numbers increased approximately $84 \%$ for co-mingled materials and $50 \%$ for paper. This accounts for approximately $24 \%$ diversion of municipal solid wastes collected at INL facilities.

The INL Site continues to utilize a number of processes to reduce the quantity and toxicity of hazardous chemicals. The processes follow the simple reduce, reuse, and recycle steps to help achieve the overall goal. The INL Site utilizes chemical coordinators and environmental personnel to help ensure the requested materials are actually needed, are not available through an exchange/sharing program, and the smallest/most appropriate quantity is being ordered. INL also stipulates the use of Massachusetts Institute of Technology (MIT) Green Chemical alternatives list at (http://web.mit.edu/environment/academic/alternatives.html) to help chemical coordinators identify "greener" alternatives to chemicals being requested. INL currently shares chemicals at IRC and town facilities (and at the Site when possible); all chemicals are targeted as an overall reduction. Chemical coordinators actively search for existing inventory to preclude new purchases. For FY 2011, approximately 16 chemical transfers occurred for usage by another organization or contractor. INL is participating with other national laboratories to establish a chemical reduction guidance that will outline more specific steps and reduction goals for INL. The next steps are to keep working towards minimizing what is coming in through Procurement and increasing sharing of existing inventories because there is limited money available for disposal. INL is actively and continually working towards improvement in reduction of inventories through the avenues of acquisition, use, and disposal.

The AMWTP Hazardous Waste Management Act (HWMA)/Resource Conservation and Recovery Act (RCRA) Permit requires that the AMWTP conduct and complete a source reduction evaluation review and written plan, in accordance with the procedures and format provided in the "EPA Waste Minimization Opportunity Assessment Manual" (EPA/625/7-88/003). This review and plan was submitted to the director by March 31, 2011 and every 4 years thereafter, and must include detailed descriptions of any programs the AMWTP may have to assist generators of hazardous and mixed waste in reducing the volume (quantity) and toxicity of wastes produced.

AMWTP reduces and minimizes the quantity and toxicity of hazardous chemicals and materials through a procurement process that stresses environmentally preferable purchases. One of the objectives stated in the AMWTP management procedure for the acquisition of material and services is to use recycled-content and bio-based content materials and other environmentally preferable products and services to the maximum practicable extent. Purchase requisitions are screened by an assigned procurement specialist for environmentally preferable materials. 


\subsubsection{Performance Status}

The INL Site diverted 15.3\% (416.43 Metric Tons [MT]) of its non-hazardous solid waste in FY 2011. INL diverted 25.2\% (373.1 MT) of municipal solid waste from the landfill in FY 2011. ICP diverted 3.5\% (43.33 MT) of municipal solid waste from the landfill in FY 2011.

INL implemented two pilot projects in FY 2011 to help identify additional waste streams for diversion assessment: cafeteria waste/composting and battery recycling. Both pilot programs were initiated and carried out for several months each; however, neither appears to be economically viable. Further evaluation will be needed (funding dependent).

In FY 2011, INL held a campaign to reduce the use of paper by setting all copiers and printers to default duplex printing/copying. An average of 12 reams of paper per person has been used annually since 2007. A survey was conducted midway through the campaign, which determined that approximately $21 \%$ of copiers and printers capable of duplexing were set to default duplex. The campaign encouraged users to save paper by setting their printers to duplex default and instructed them how to do it. Even so, many employees found that it was too difficult to change the default settings. In addition, the maintenance contract for the copiers was modified to include resetting all copiers to duplex default during FY 2012.

\subsubsection{Planned Actions}

The INL Site will continue to educate and encourage employees to participate in the recycling and paper shredding programs in town and at the industrial campuses. New for FY 2012 is an interactive drag and drop recycling quiz that was incorporated into the all employee ES\&H refresher training and placed on the Recycling Program's internal website.

The INL Site will continue to evaluate potential outlets and the expansion of recyclable waste streams, such as cafeteria grease, fluorescent light tubes, batteries, and food wastes, to further increase the amount of wastes diverted from the landfill.

The INL Site will continue to reduce printing paper used through a campaign for users to set printers and copiers to duplex printing. Centrally managed printing will be evaluated.

The INL Site anticipates meeting this goal if funding is allocated to optimize the current waste diversion systems, modify contracts, and markets are available to divert waste streams.

\subsection{Construction and Demolition Waste Diversion}

\section{Divert at least 50\% of construction and demolition materials and debris, by FY 2015.}

INL has incremental goals for construction and demolition waste, increasing 10\% per year from 2011 through 2015. INL exceeded the FY 2011 goal of 10\% diversion.

The diversion of construction and demolition debris during D\&D activities for ICP is often problematic due to the potential for radioactive contamination. Diversion of D\&D waste is often quite costly and the wastes are usually disposed of onsite.

\subsubsection{Performance Status}

The INL Site diverted 12\% of its construction and demolition (C\&D) in FY 2011 (1,705.73 MT).

The majority of AMWTP and ICP C\&D waste is prohibited from offsite reuse due to the DOE moratorium. Construction waste and landfill acceptance data is analyzed quarterly to track performance against the goals. INL diverted $39.4 \%(3,233,350 \mathrm{lbs})$ of construction and demolition (C\&D) waste during FY 2011. This included C\&D soil reused as landfill cover and asphalt regeneration. The tracking system for waste material sent to the landfill was enhanced to better categorize conditional waste into the following subcategories: concrete, metal, soils, and furniture. This will allow INL to analyze this waste stream and determine if segregation is viable. 


\subsubsection{Planned Actions}

INL intends to perform the following actions to enhance the $C \& D$ waste diversion process:

- Incorporate metals recycling into one pilot D\&D task when allowed under the current recycling moratorium

- Analyze the conditional waste stream to better develop segregation and reuse strategies

- Develop a process to accurately measure the wood waste diverted to the wood chipper

- Engage construction subcontractors to solicit best practice ideas relative to the INL logistics and market potential.

ICP will evaluate D\&D and other waste streams for recycle and reuse dependent upon reasonableness of costs compared to onsite disposal as well as the metals moratorium and potential for radioactive or chemical contamination. 


\section{SUSTAINABLE ACQUISITION \\ 6.1 Sustainable Acquisition}

\section{Procurements meet sustainability requirements by including necessary sustainable provisions and acquisition clauses (95\% each year).}

DOE's SSPP commits to the following sustainable acquisition goals:

- Ensuring 95\% of new contract actions, including task and delivery orders under new contracts and existing contracts, require the supply or use of products and services that are energy efficient (ENERGY STAR or FEMP-designated), water efficient (WaterSense), biobased, environmentally preferable (including EPEAT-registered products), non-ozone depleting, contain recycled content, or are non-toxic or less toxic alternatives.

- Updating departmental sustainable acquisition plans (previously known as green purchasing plans or environmentally preferable purchasing plans), policies, and programs to ensure that all federally mandated designated products and services are included in all relevant acquisitions.

\subsubsection{Performance Status}

The INL Site did not meet the $95 \%$ sustainable provisions goal. ICP is not contractually obligated and only tracks FEC materials. INL put a system in place in FY 2011 and preliminary data runs indicate 31\% of the contracts in FY 2011 contained applicable clauses. This does not meet the goal, but changes to contract acquisition systems are timely and costly with little benefit to contracts that are service based. However, INL made great progress and is incorporating the Sustainable Acquisition requirements through effective implementation of procedures, policies, and enhanced work processes that increase the visibility, availability, and use of sustainable products.

- INL enlisted the help of a Sustainable Acquisition offsite expert to provide training to over $125 \mathrm{INL}$ employees who use, procure, or have contract oversight of sustainable acquisitions products. Training helped focus key user groups on which items to request, why INL needs to procure these products, and how to request. Additionally, HS-22 provided an HQ perspective on sustainable acquisitions.

- INL awarded a long-term contract for janitorial products with the latest sustainable acquisition language. Vendor requirements were also included to provide detailed reports of purchased products that are defined as preferred with dollars indicating the amounts that were or were not considered to be preferred.

- In addition to defining a way to track contract acquisitions against the $95 \%$ goal, INL flagged hundreds of potential commodity codes related to sustainable acquisition products, thereby greatly reducing the number of purchases requiring further review in an effort to enhance automated tracking and reporting within the current system.

- Preference program: INL's automatic document generation system ensures applicable contracts include language that favors the acquisition of recovered content products. For example, INL requires its supplier of standard desktop computers to provide items designated as Electronic Product Environmental Assessment Tool (EPEAT) Silver or better.

- Estimation, Certification, and Verification: INL requires suppliers (e.g., construction services, office products, paper products) to deliver spend reports listing the designated versus preferred purchases. In addition, INL has developed standard reports that provide the summary data necessary for reporting spend for recycled content products.

- Annual Review and Monitoring: INL conducts an annual review and assessment of a specific aspect of the sustainable acquisition program. 
- Sustainable acquisition requirements prior to FY 2011 were incorporated in DOE-ID major site contracts.

The ICP material acquisition process directs procurement to use recycled-content and bio-based content materials and other environmentally preferable products and services to the maximum extent practicable.

\subsubsection{Planned Actions}

In recent years, there continued to be many changes and additions in sustainable acquisition requirements. INL plans to perform the following actions to improve its sustainable acquisition program:

- Incorporate sustainable acquisition language into janitorial and construction contracts

- Develop appropriate mechanisms to augment the existing reporting requirements and track compliance with this goal

- Enhance the current ordering system to increase sustainable acquisition visibility to the laboratory community

- Ensure personnel resources are adequate and aligned in accordance with the proper organizational roles and responsibilities

- Conduct a campaign to increase the education and awareness of sustainable acquisitions and their effect on certain INL performance requirements

- Benchmark processes with other laboratories to leverage lessons learned and to discover potential improvements to INL's process. 


\title{
7. DATA CENTERS AND ELECTRONICS STEWARDSHIP 7.1 Data Center Metering
}

\author{
All data centers are metered to measure a monthly Power Utilization Effectiveness (PUE) (100\% by \\ FY 2015).
}

The INL Site has two data centers. The first is INL's Information Operations and Research Center (IORC), which is the primary location for the business enterprise servers and data repository. This data center hosts business systems, e-mail, project applications, and the primary infrastructure systems for INL. The second data center is in EROB and is the location for the High Performance Computing (HPC) servers and storage.

\subsubsection{Performance Status}

The HPC data center in EROB was metered when it was constructed in FY 2007. In FY 2011, these meters were connected to INL's i-Vue building control system.

\subsubsection{Planned Actions}

The IORC facility has two City of Idaho Falls electric meters, but the data center is not separately metered from the rest of the office space. INL intends to implement metering for just the data center so that a correct PUE can be measured and calculated.

\subsection{Data Centers PUE Measurement}

\section{Maximum annual weighted average Power Utilization Effectiveness (PUE) of 1.4 by FY 2015.}

\subsubsection{Performance Status}

In FY 2007, INL completed construction of the 3,700 $\mathrm{ft}^{2}$ data center in EROB to support HPC resources and also ensured it would support the strategy and necessity to expand to $10,000 \mathrm{ft}^{2}$ in the future. Several practices were incorporated to assist with energy efficiency goals for the laboratory.

- The data center space was right-sized to minimize the associated operating energy costs.

- Cooling for the data center uses a green solution called "free cooling" when appropriate. As long as the outside temperature ranges between $40^{\circ} \mathrm{F}$ and $-31^{\circ} \mathrm{F}$, and the temperature of the water leaving the data center is not too high, the chillers do not operate. Using a "flat plate" to extract the heat from the data center water and transfer that heat to the cooling towers without chillers saves a considerable amount of energy.

- INL's large computer clusters include water-cooled doors to improve the overall cooling efficiency of the data center. The exhausted warm air from the compute nodes is immediately cooled as it passes through the rear cooling doors on the racks and reenters the room at temperatures near those of the open air in the data center. The computer room air condition (CRAC) units are cooled by the chilled water and are required to do less work, which reduces electricity consumption.

- Finally, the last HPC cluster procured was designed using the latest technologies in high-density processors from Advanced Micro Devices, Inc. Having four 8-core processors in each node (versus traditional configurations) greatly reduced the requirements for space, power, and cooling of the entire system. The configuration includes fewer racks, fewer nodes, less network infrastructure, and fewer power supplies, all resulting in less consumed power.

As a result of these efforts, the HPC data center has a calculated PUE ranging from 1.3 to 1.4, depending on system load and outside weather conditions (see Table 6). 
Table 6. INL HPC data Center PUE.

\begin{tabular}{|c|c|c|c|}
\hline $\begin{array}{c}\text { Instantaneous Power } \\
\text { (May 19, 2011) }\end{array}$ & $\begin{array}{c}\text { Consumption } \\
(\mathrm{KW})\end{array}$ & $\begin{array}{c}\text { 3-Year Power } \\
\text { (February 2008-May 2011) }\end{array}$ & $\begin{array}{c}\text { Consumption } \\
(\mathrm{KW})\end{array}$ \\
\hline Compute & 420 & Compute & 7018 \\
\hline Cooling & 140 & Cooling & 2750 \\
\hline PUE & 1.3 & PUE & 1.4 \\
\hline
\end{tabular}

In addition, to achieve greater operational efficiency, Information Management (IM) has embraced numerous emerging technologies within the two data centers by the following industry standard practices:

- Virtualizing and consolidating the server. Currently, more than half of INL servers are running in a virtual environment.

- Investing in new high-efficient server and uninterruptable power supply (UPS) hardware and replacing the legacy systems.

- Implementing facility best practices to reduce energy use.

- Redesigning Data Centers and establishing hot and cold aisles to decrease air conditioner usage.

- Removing old cabling under the floor to improve air flow.

- Investigating using newer network equipment that will utilize higher bandwidth with less equipment and port needs (Cisco Nexus).

- Purchasing Energy Star rated equipment where applicable.

The IORC data center PUE calculates at greater than 3.0, but this calculation includes the entire building, not just the data center.

\subsubsection{Planned Actions}

Virtual Machine (VM) Server Farms - INL IM will promote the use of virtual servers (one physical server computer which may use several virtual instances of server computers) wherever possible in place of single purpose servers.

VM Desktops - IM will promote the use of virtual desktops on one physical desktop computer for users who need to use several different operating systems.

Desktop Refresh Initiative (DRI) - When the end of the year overall INL budget allows, IM will also facilitate the desktop refresher initiative that purchases newer, more efficient computers to replace older wasteful desktop computers and laptops.

As part of ongoing activities, IM will continue to upgrade and consolidate servers. Additional planned activities include popular data center practices such as increasing the data center room temperature by approximately $10^{\circ} \mathrm{F}$. This by itself should provide further savings without additional risk. The data center control system is a "Carrier" system with a large number of monitoring and control points. This system will be further enhanced to provide better day-to-day monitoring, trending, and reporting. Other options are being considered at such as powering down unused computer nodes to save additional power.

Lastly, the data center in IORC will be separately metered and the correct PUE calculated. 


\subsection{Electronic Stewardship}

\section{Electronic Stewardship - 100\% of eligible PCs, laptops, and monitors with power management actively implemented and in use by FY 2012.}

\subsubsection{Performance Status}

The INL Site has been a partner in the Federal Electronics Challenge (FEC) since FY 2007. INL's participation in the FEC is supported by representatives from procurement, information management, property management, and environmental support services. Through continuous improvement, INL has emerged as a leader in electronics stewardship as evidenced by winning the FEC Bronze award in FY 2007 and FY 2008, the FEC Silver award in FY 2009 and FY 2010, and the FEC Bronze in FY 2011. More specifically:

- Power management settings are installed on all eligible computers, a process started several years ago. In FY 2011, INL updated these settings to ENERGY STAR values. Information Management uses a centrally managed configuration tool (LANDesk) to set and maintain the power management settings on all Information Technology (IT)-managed and jointly managed computers. Administrators of self-managed computers (computers that are not manageable with LANDesk) are given instruction on how to set the power management settings on their computers. Exemptions from these power management settings are tracked in IM's Remedy database and are approved after valid business justifications for exemptions are provided.

- In FY 2011, INL held a campaign to reduce the use of paper by setting all copiers and printers to default duplex printing/copying. An average of 12 reams of paper per person has been used annually since FY 2007. A survey was conducted midway through the campaign, which determined that approximately $21 \%$ of copiers and printers capable of duplexing were set to default duplex. The campaign encouraged users to save paper by setting their printers to duplex default and instructed them how to do it. Even so, many employees found that it was too difficult to change the default settings. In addition, the maintenance contract for the copiers was modified to include resetting all copiers to duplex default during FY 2012.

- INL promotes the standard for new electronic equipment and hardware to be a minimum of Energy Star 5.0 Category B rating and wherever possible Category A Energy Rating. Dell Energy Smart is enabled from the manufacturer. Dell ESMART settings are used wherever possible.

- Up to $88 \%$ efficient power supplies are used on standard desktop computers.

- In FY 2011, 94\% of INL's purchased computers, liquid crystal displays (LCDs), and laptops were EPEAT registered. The INL standard for procurement of desktop computers, workstations, and laptops is to meet or exceed EPEAT Silver and wherever possible EPEAT GOLD standards.

- INL property services reuses computers and other electronics through disposal via reutilization, donations, transfers, and sales. These methods meet the GSA definition for recycling electronic property, resulting in over 99\% reuse during FY 2011.

ICP has also been a partner in the FEC and was awarded the FEC Bronze award in FY 2011. Power management settings are available on personal computer systems. Implementation of power management has not been implemented due to IT operations requirements.

It is AMWTP's policy to procure only ENERGY STAR-compliant computer monitors with ENERGY STAR Power Management features enabled as part of the standard load. The AMWTP IT Infrastructure Group has an established policy stating that all eligible computers and monitors must have Energy Star features that allow AMWTP to comply with the DOE's mission while ensuring effective energy conservation. The Group has implemented configurations and mechanisms on eligible systems to automatically execute energy conservation measures. Certain production and plant operations systems 
were excluded from this policy, for example control room systems and camera monitors, as those systems are safety and operations related and must remain in the "on" position. AMWTP employees are prevented from making changes to these settings by cyber security policies that are in place on all AMWTP systems.

\subsubsection{Planned Actions}

INL will continue to focus efforts that are cost effective and least disruptive to performers. Specifically:

- Incorporate power management on printers, including duplex printing as well as update LWP-1316, "Power Management for Personal Computers," and communicate the changes and expectations via iNotes, Lunch and Learns, etc. (EMS FY 2012 target).

- Build upon the network printing initiative and the potential managed service for printing to evaluate centrally managed printing (EMS FY 2012 target).

- Require all new networked printers to support duplex printing as part of INL's printer standards (EMS FY 2012 target).

- Communicate, participate, and encourage personnel to recycle/reuse computer and cellular/wireless equipment, and recycle with vendors as appropriate (EMS FY 2012 target).

- Continue to ensure that $95 \%$ of all desktop, laptop, and monitor purchases are EPEAT/ENERGYSTAR compliant; extend the standards to printing and imaging equipment (EMS FY 2012 target).

- Further establish and implement policy and guidance to ensure the use of Power Management and other energy efficient or environmentally preferred options and features on all eligible electronic products.

- ICP will continue to work with IT to evaluate options for implementing power management while maintaining system availability requirements. 


\section{REGIONAL AND LOCAL PLANNING}

Executive Order 13514 instructs federal agencies to meet the following regional and local planning goals:

- Participate in regional transportation planning and recognize existing community transportation infrastructure

- Align federal policies to increase the effectiveness of local planning for energy choices such as locally generated renewable energy

- Ensure that planning for new federal facilities or new leases includes consideration of sites that are pedestrian friendly, near existing employment centers, accessible to public transit, and emphasize existing central cities and, in rural communities, existing or planned town centers

- Identify and analyze impacts of energy use and alternative energy sources in all Environmental Impact Statements and Environmental Assessments for proposals for new or expanded federal facilities under the National Environmental Policy Act of 1969, as amended (42 U.S.C. 4321 et seq.)

- Coordinate with regional programs for federal, state, tribal, and local ecosystem, watershed, and environmental management.

\subsubsection{Performance Status}

As the INL Site primary contractor responsible for land management and sitewide leadership, INL maintains excellent relationships with local community planning and government groups, including the cities of Idaho Falls, Blackfoot, Arco, and Pocatello, as well as the counties of Bonneville, Butte, Bingham, and Bannock. Interactions include transportation infrastructure, facility planning locations, traffic patterns, and future infrastructure needs. When warranted, the community is involved and encouraged to supply feedback to decision makers during any National Environmental Policy Act public process.

Although limited, existing community transportation infrastructure usage is encouraged and INL works with multiple local and state agencies on transportation planning by providing input and sponsoring awareness events to promote employee commuting ridership. In FY 2011, INL worked with local transportation companies to coordinate a schedule for riders to the Blackfoot and Pocatello areas.

The bicycle remains a popular seasonal method of commuting at the Idaho Falls campus with increasing awareness of personal fitness and energy conservation. Facilities have designated bicycle spaces and INL continues to explore the possibility of covered parking for cycling and motor cycle commuters.

Sustainable Site development encompasses an integrated approach during the refurbishment and planning of future onsite facilities and infrastructure, consistent with the INL TYSP. INL encourages walking and bicycling as means of travel within Site boundaries; long-range Site development envisions continuous improvement of a bicycle- and pedestrian-friendly environment.

INL continues to work with the following local planning organizations:

- Idaho Strategic Energy Alliance

- Yellowstone Business Partnership (INL representative is on the Board of Directors)

- Yellowstone-Teton Clean Cities Collation

- Bonneville County Transportation Committee

- Targhee Regional Public Transportation Authority. 


\section{SITE INNOVATIONS}

The energy and environment mission of the Laboratory is derived from research, development, and demonstration capabilities in specific areas of clean energy supply and in developing engineering solutions needed to enable the integration of energy systems. INL provides an internationally recognized applied energy engineering research capability used to assist the U.S. achieve environmentally responsible energy security. Emphasis is placed on advancing deployment of technologies that enhance clean energy development, delivery, use, and efficiency, and addresses management of energy-related materials and environmental consequences.

INL is one of DOE's three recognized "energy" laboratories with a principle focus on nuclear energy R\&D. The Laboratory serves a diverse set of customers providing research, development, demonstration, and deployment (RDD\&D) that provides impactful and environmentally responsible energy development, delivery and use. INL emphasizes an engineering research and energy systems approach, strongly steeped in technology, testing and demonstration, which is designed to reduce risks associated with deployment of energy technology. This capability is to be underlain by a strong science foundation.

INL focuses on advanced energy system component integration and system design and analyses comprising the following elements: (1) process modeling and analysis, (2) feedstock production and processing, (3) energy integration and heat transfer, (4) energy storage and product synthesis, (5) byproduct management, (6) process and system monitoring, control, and maintenance. This focus couples engineering models with testing, instruments, monitoring, and control schemes to support optimal energy systems design, energy resource optimization, total carbon/water management, and hybrid energy systems. As part of this effort, INL has become an internationally recognized thought leader in hybrid energy systems.

DOE views biofuels as a high priority in achieving its goal to help the U.S. lessen its dependency on oil for transportation. And Department of Defense (DOD), as an end user, is being very aggressive relative to securing drop in biofuels to meet its mandates. The goal of INL's Bioenergy Program is to overcome key technical barriers facing the U.S. bio-energy industry by systematically researching, characterizing and modeling, demonstrating, and harnessing the physical and chemical characteristics of the nation's diverse lignocellulosic biomass resources to produce biofuels and other value-added products more cost-effectively. INL maintains a strong national and international competitive position with biofeedstocks (logistics, preprocessing, characterization), but also maintains capabilities in biochem conversion, thermochem conversion, biopower, strategic analysis, sustainability, and algae. Providing strength to this platform are experts and testing and demonstration equipment, including the Process Demonstration Unit (PDU).

The transition to hybrid electrical and all-electrical light-duty vehicles for personal transportation has the potential to shape the demand curve for electricity in the U.S. However, realization of this advanced technology will require improvements in batteries, energy conversion, and electrical infrastructure - all of which are established areas of INL expertise. The INL's integrated vehicle, energy storage, and grid demonstration and testing laboratory is a regional and national testing and demonstration resource for DOE, DOD, other federal agencies, and industry.

INL is the lead DOE laboratory for field performance and life testing of advanced technology vehicles and DOE has recently identified electrification of light-duty vehicles as its highest priority in helping reduce dependency on oil. The Laboratory provides benchmark data for DOE technology modeling, simulations, and R\&D, as well as to fleet managers and other vehicle purchasers for informed purchase, operations, and infrastructure decisions. INL is coordinating plug-in demonstration projects with private companies and city, county, port, and environmental agencies. Onboard data-loggers, cellular modems, and GPS units transmit information from these vehicles to INL researchers for analysis. 
INL's applied battery research and diagnostic testing includes thermodynamic life analysis of advanced battery chemistries under development and advanced physical and materials modeling. DOE is heavily invested in qualifying existing and new battery concepts and materials that could dramatically lower the costs and increase the performance of batteries for use in electric vehicles, which in turn will help lessen dependence on oil as a transportation fuel. There has also been increased interest in integrating utility scale batteries, which is of import to greater integration of renewable energy resources and support various hybrid energy system approaches. These applications are also of significant interest to DOD, either at their domestic bases, forward bases, or soldier power. INL is also pursuing relevant research in battery advanced materials and diagnostics.

Given current U.S. interest and investment, traditional renewable energy (e.g., hydropower, wind power, geothermal power, and solar power) has experienced significant growth, over the last several years. As a result, INL has begun to redevelop in areas where it previously had stature in DOE. In addition, INL has longstanding position with DOD addressing renewable energy use in support of aggressive renewable energy consumption and fossil fuel reduction goals. INL's niche in conventional renewable energy is providing applied engineering research to advance geothermal resources, wind power, and water power, as well as practical integration of renewable energy resources. INL is focused on resource assessments, renewable energy grid integration, mechanical design, reservoir assessment and monitoring, heat transfer, and advanced control systems.

Water is a critical resource intricately connected to energy development and is increasingly a critical factor in energy investment and regulatory decisions associated with nuclear, fossil and renewable energy development. The importance of water resources relative to energy will only increase as greater demands are imposed on water resources, in particular in the more arid west, where there is pressure being applied to reduce depletion of aquifers and rivers and protect water resources from contamination. Other needs relate to use of energy in the development and use of water, itself, including for irrigation and desalination. INL focuses primarily on water resources from a perspective of their role in energy development and use, with a greater emphasis on (1) assessing potential impacts on water supply and quality, (2) providing technology, testing, demonstration to responsibly produce/use water, and (3) addressing energy efficiency in support of water production/use. INL brings a number of capabilities to address this area, including modeling, field and laboratory testing, membrane technology, microbiology, and instrumentation.

Advancing energy resource development requires responsibly addressing and mitigating impacts on the environment including on the air shed, soils, water, wildlife, and landscape whether from fossil, renewable energy, nuclear energy, energy infrastructure emplacement. Energy production and distribution require the development and use of multiple natural resources and often compete with other important resource uses such as food production, residential development, recreation, and other industrial applications. Of particular note are impacts associated with oil, gas, and coal development. INL focuses primarily on environmental technology from a perspective of its role in advancing solutions oriented, environmentally responsible, energy development with a greater emphasis on (1) assessing potential impacts on the environment and (2) providing technology development, testing and demonstration to support responsible energy development. Ecosystem and regional-level analysis tools based on Geospatial Information Systems (GIS) and system-dynamics modeling techniques are being developed to analyze energy and natural resource development and use. They also identify systems that address fluctuations in demand and availability of resources and energy in the short and long term. INL researchers have and continue to develop advanced environmental forensics capabilities to detect trace levels of specific chemicals and other small changes in the environment. 


\section{CLIMATE CHANGE ADAPTATION}

The Intergovernmental Panel on Climate Change defines adaptation as, "adjustment in natural or human systems in response to actual or expected climatic stimuli or their effects, which moderates harm or exploits beneficial opportunities." The process of understating and planning climate change adaption strategies is still beginning. Specific INL climate change impacts and understanding how to best respond to these impacts is rapidly evolving. Because of this, INL climate change strategic planning will be designed as a continuous, flexible process and subjected to periodic review and revisions.

As with any new national initiative, meaningful and sensible indicators need to be identified or developed. However, it is difficult to develop specific, quantifiable indicators when applied to DOE operations at a national laboratory. That does not mean that INL will ignore operational impacts on climate change. Over the past 5 years, INL has continually demonstrated a willingness to reduce operations impacts. This is evidenced through petroleum use reduction, material recycle, efficiency upgrades, optimizing operations, and millions of research dollars spent on energy research.

To that end, INL will use the following steps to develop, vet, and implement a climate change adaption strategy:

1. Prioritize adaptation efforts where vulnerabilities are highest (what is causing the most damage which will result in the biggest benefit when corrected)

2. Integrate adaptation into long-term sustainable strategies (policies, operations, buildings, business decisions)

3. Strengthen existing programs and capabilities (continued excellence in fleet fuel reductions and research capabilities)

4. Develop a robust strategy to allow for rapid deployment in the face of changing policy (applicable efficiently and cost effectively)

5. Leverage opportunities from within and outside the laboratory expertise (community involvement, regional planning, national resources; do not reinvent the wheel). 
Appendix A

Glossary 
(This Page Intentionally Left Blank) 


\section{Appendix A}

\section{Glossary}

Alternative Fuel. A vehicle or equipment fuel that is either not petroleum based, or significantly reduces the petroleum content of the fuel. Biodiesel blends such as B20 (20\% biodiesel) and Ethanol blends such as E-85 (85\% Ethanol) are the more common alternative fuels. Compressed natural gas (CNG) and liquefied natural gas (LNG) are also recognized alternative fuels that are not a blended fuel.

Alternative Fuel Vehicle. Alternative fuel vehicles (AFV) are specially designed to run on an alternative fuel. They can be dedicated to a single alternative fuel such as LNG, or they can be dual fuel capable of operating on both alternative such as CNG or E-85 and gasoline. Diesel engine vehicles that can simply be operated on a biodiesel blend are usually not considered AFVs.

Commissioning. A process of ensuring that all building systems are installed and perform interactively according to the design intent, the systems are efficient and cost effective and meet the owner's operational needs, the installation is adequately documented, and the operators are adequately trained.

Commissioning Authority. The individual hired by, or responsible to, the building owner and is tasked with implementing the commissioning process for a new or existing building. The Commissioning Authority is typically responsible for all aspects of the commissioning process, leads and trains the commissioning team, and witnesses or verifies all system checks or inspections throughout the process. The Commissioning Authority has final jurisdiction for the entire commissioning process.

Continuous Commissioning. Continuous commissioning involves ongoing monitoring and testing of systems as part of a regular maintenance plan to ensure optimum performance and enhanced equipment longevity. Continuous commissioning can be at a system or a building level depending upon the requirements of the stakeholders.

Energy Efficiency. The ability of a building to minimize the amount of energy used for employee safety, health, and comfort. Energy efficiency also applies to the processes that are performed inside the building, which are not necessarily part of the physical structure. Energy efficiency improvements should always be measured by life cycle cost effectiveness, and not by first cost or simple payback.

ESPC. Energy Savings Performance Contracts (ESPC) are projects that are developed, engineered, performed, and funded by an outside contractor called an Energy Services Contractor (ESCo). ESPCs are paid for through the energy savings derived from the project and are intended to be a no-cost turn-key process or project. The annual payments are made to the ESCo with funds that would have been distributed to the utility. ESPCs are especially useful when capital funding is not readily available. DOE sites can take advantage of the Super ESPC program, which provides pre-evaluated ESCos familiar with federal processes.

HVAC. Heating, ventilating, and/or air conditioning (cooling) systems in a building. HVAC systems include all components, controls, and distribution systems needed to deliver conditioned air to the desired point of use.

Indoor Environment. A building's indoor environment includes many factors including the quality of the air in and supplied to the building, temperature levels, and consistency throughout the building, amount of pollutants in the workspace, lighting levels, and quality, levels of unwanted sound, and amount of day lighting.

INL Site. All contractors and activities at the INL Site under the control of the DOE-ID Operations Office, but excludes the Naval Reactors Facility (NRF). 
LEED $^{\mathrm{TM}}$ Rating System. Leadership in Energy and Environmental Design $\left(\mathrm{LEED}^{\mathrm{TM}}\right)$ is a tool for green building design to help design teams and owners determine green project goals, identify green design strategies, measure and monitor progress, and document success. The LEED ${ }^{\mathrm{TM}}$ Rating System was developed and is administered by the U.S. Green Building Council (USGBC), which is a national nonprofit organization that includes representation from all aspects of the building industry. The LEED ${ }^{\mathrm{TM}}$ Rating System is a point system of five technical categories and four levels of certification: LEED $^{\mathrm{TM}}$ Certified, Silver, Gold, and Platinum.

Low-Cost. Low Cost modifications or repairs may be performed during the commissioning process, but are typically implemented shortly after. Low-cost opportunities typically cost less than $\$ 500$ and can be accomplished in bundled groups.

No-Cost. Adjustments or modifications that can be made during the commissioning implementation phase by in-house crafts. These on-the-spot modifications are essentially no-cost other than the time for the craft person to be available. No-cost adjustments should be maximized during the implementation phase.

Re-commissioning. Commissioning that is performed several years after a building, which was previously commissioned, has been in operation to ensure that the building and systems are meeting the original design requirements. Re-commissioning is typically used to identify and correct malfunctions in a building that occur as the building ages and to ensure continued indoor air quality, employee productivity, and energy efficiency. Re-commissioning can also be used to address changes in ownership, building use patterns, and operation and maintenance practices. A building's use and mission often change during the building's life and these changes necessitate the need for re-commissioning to ensure that the building is capable of efficiently meeting its new and/or evolving mission.

Retro-commissioning. Applying the commissioning process to a building that has never been commissioned. Retro-commissioning is sometimes referred to as "Existing Building Commissioning" and is used to compare the building's original design parameters and operational criteria with current design and operational requirements. Retro-commissioning determines if the building is capable of meeting its current mission needs and identifies modifications required to meet those needs. Retro-commissioning then identifies upgrades to the building that will enhance its energy efficiency, tenant comfort and productivity, and indoor air quality. Retro-commissioning as a best practice means using a whole building approach to ensure that the building is operating within well-defined criteria established by the building stakeholders.

Sustainability. The ability of a society to operate indefinitely into the future without depleting its resources. Sustainability includes concepts of green building design and construction, reuse and recycling of materials, reduced use of material and energy resources for building construction and operation, water conservation, and responsible stewardship of the environment adjacent to the building. 
Appendix B

\section{Excluded Buildings Self-Certification}


(This Page Intentionally Left Blank) 


\section{DOE BUILDING EXCLUSION \\ SELF-CERTIFICATION FORM}

FY 2011

FROM: DOE Idaho Operations Office, Idaho National Laboratory Site

Lead Program Office is the Office of Nuclear Energy

TO: Sustainability Performance Office

DATE: January 19, 2012

\section{SUBJECT: SELF-CERTIFICATION FORM FOR THE ENERGY INTENSITY GOAL OF EISA 2007}

Each buildings or group of buildings excluded under the criteria for a Part G or Part $\mathrm{H}$ exclusion is/are metered for energy consumption and their consumption is reported annually.

If any building has been excluded under the criteria for Part $\mathrm{H}$ for impracticability then all practicable energy and water conservation measures with a payback of less than 10 years have been installed. A justification statement that explains why process-dedicated energy in the facility may impact the ability to meet the goal has been provided in the FIMS Report 063.

I certify that the buildings listed on the Excluded Buildings List produced by FIMS as Report 063 dated 14 November 2011, for the Idaho National Laboratory Site on pages 53 through 54 meet the exclusion criteria in Guidelines Establishing Criteria for Excluding Buildings published by FEMP on January 27, 2006.

Teresa Perkins

DOE Site Office Official - printed name

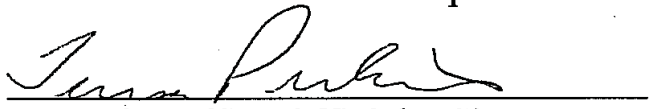

DOE Site Office Official - Signature

$\frac{1 / 19 / 20 / 2}{\text { Date }}$

Contact Information:

Teresa Perkins, Director

Environment and Sustainability Division DOE-ID

Phone: (208)526-1483

eMail: perkint1@id.doe.gov

Or: Ernest Fossum,

INL Energy Manager (208)526-2513

Ernest.Fossum@inl.gov 


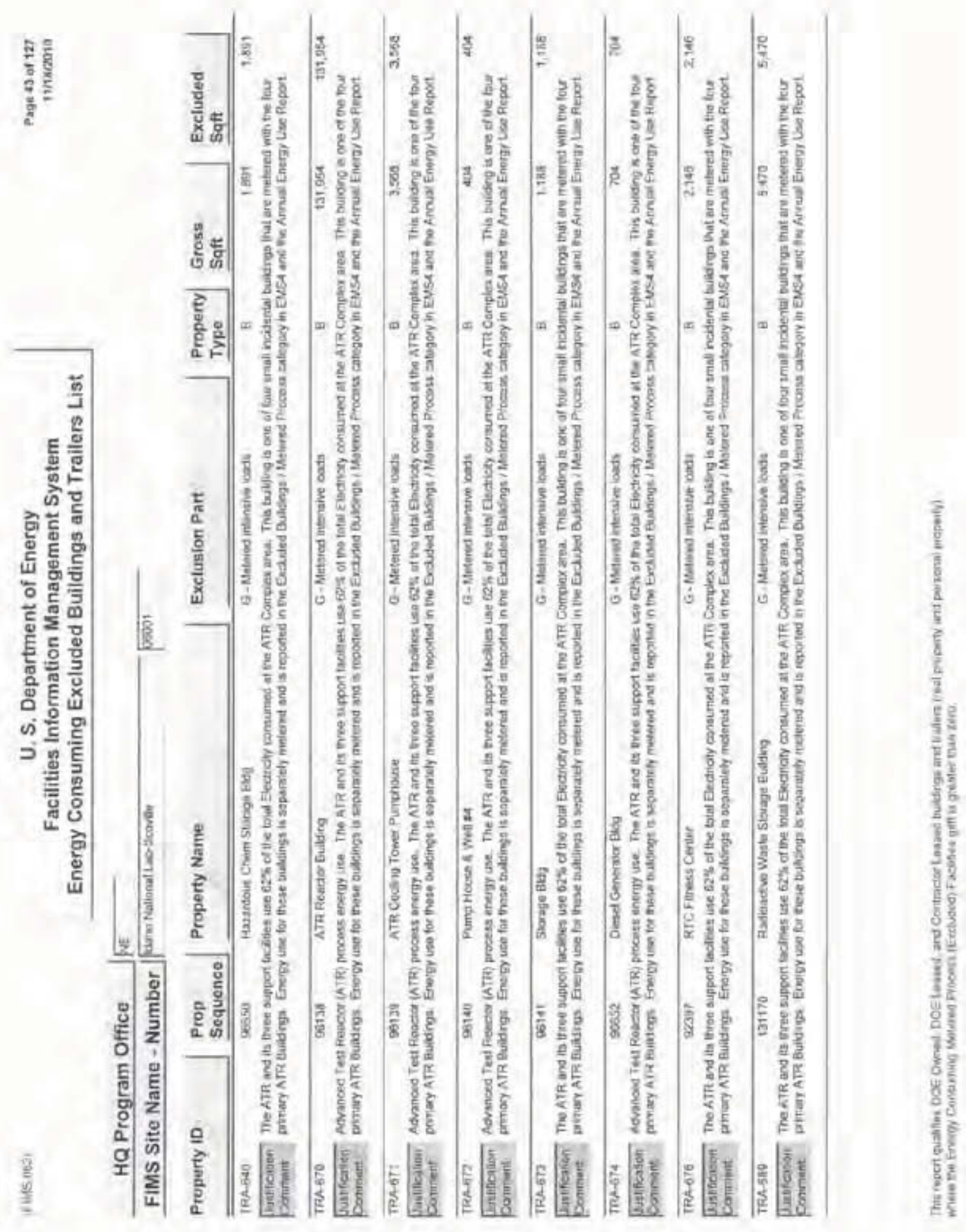




\section{Appendix C}

Consolidated Energy Data Report (CEDR) 
(This Page Intentionally Left Blank) 
FY 2011 Encrgy Maragement Data Report

\begin{tabular}{|c|c|c|c|}
\hline Frograte &  & Prepared by: & 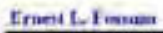 \\
\hline Stite: & Whate Nitimal I =liesation? & Phan: & (204,596.2513 \\
\hline thical xeat & DII & Dale: & 12/63e11 \\
\hline
\end{tabular}

Exsoinmertior see tobles

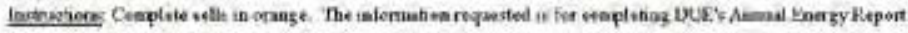

Sians, Silic

ENFRGY ENTICIEXCY IMPROVTMIETS AND TIUNDING

\begin{tabular}{|c|c|c|c|c|c|c|}
\hline \multirow[b]{3}{*}{ 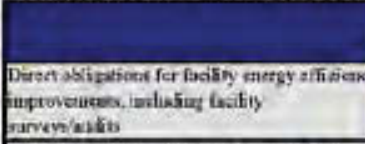 } & \multicolumn{2}{|c|}{ FY 2311} & \multicolumn{2}{|c|}{ Prefectad ES zatz } & \multicolumn{2}{|c|}{ Propeded Es zals } \\
\hline & & (Then, 5 ) & & (Mhail 5 ) & & $(1 \mathrm{H}, \mathrm{n}, 5)$ \\
\hline & & $5 \operatorname{sas} 4$ & & Strano- & & st.mose. \\
\hline 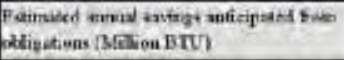 & 13ss.1 & 5127 & $5.587,9$ & $5(\infty), 1$ & Gental & 5top.s. \\
\hline 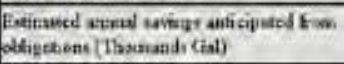 & 0.0 & 190 & $1.920,0$ & 530 & $8 . \mathrm{A}$ & se.e. \\
\hline
\end{tabular}

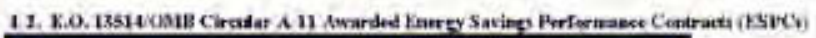

\begin{tabular}{|c|c|c|}
\hline & 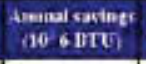 & (Nuadber Thas S) \\
\hline 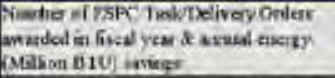 & 0.0 & of \\
\hline \multicolumn{2}{|c|}{ 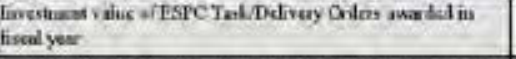 } & 500 \\
\hline \multicolumn{2}{|c|}{ 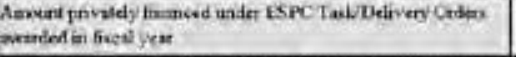 } & 300 \\
\hline \multicolumn{2}{|c|}{ 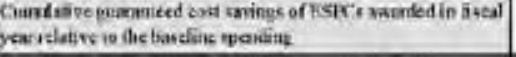 } & 500 \\
\hline \multicolumn{2}{|c|}{ 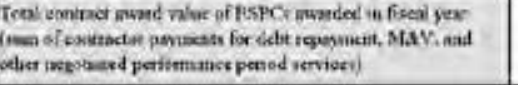 } & 300 \\
\hline \multicolumn{2}{|c|}{ 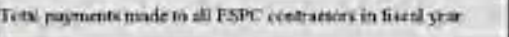 } & SS,Jas:s \\
\hline
\end{tabular}

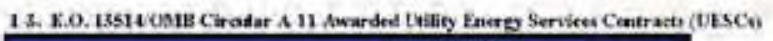

\begin{tabular}{|c|c|c|}
\hline & 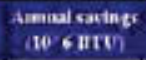 & (Nendber Thas 5) \\
\hline 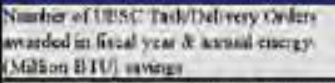 & $a 0$ & $0 R$ \\
\hline \multicolumn{2}{|c|}{ 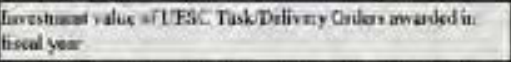 } & boi \\
\hline \multicolumn{2}{|c|}{ 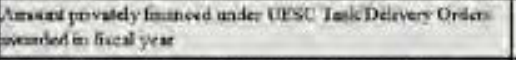 } & $30 \mathrm{C}$ \\
\hline \multicolumn{2}{|c|}{ 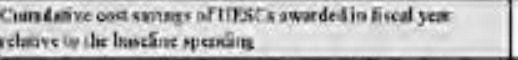 } & 500 \\
\hline \multicolumn{2}{|c|}{ 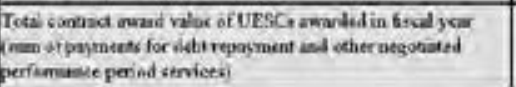 } & $\$ 0 \mathrm{C}$ \\
\hline \multicolumn{2}{|c|}{ 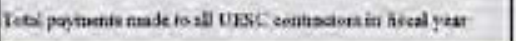 } & $\operatorname{sic}$ \\
\hline
\end{tabular}

\section{KPAd 1992 Traluing:}

\begin{tabular}{|c|c|c|}
\hline & (Ninuber) & (1) \\
\hline 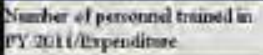 & 21 & sts: \\
\hline
\end{tabular}


FY 2011 Energy Management Data Report

\begin{tabular}{|c|c|c|c|}
\hline Prograne & Departieseat of Linergy & Propared by: & Ement 1, Y Ymana \\
\hline Silter: & Idale Nintianal Laheratory & Phoset & $12085) 526.2513$ \\
\hline Fineal Year: & 2011 & Date: & $126 / 2011$ \\
\hline
\end{tabular}

Beginganife: Ses tahles

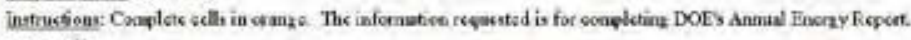

5encs: site

1-5a. VPAd zoed Mearize or Vecricity tise

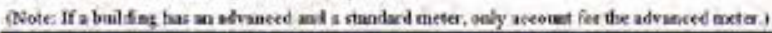

\begin{tabular}{|c|c|c|c|c|c|c|c|c|}
\hline \multirow[b]{2}{*}{ Hereal Vere } & \multirow{2}{*}{ 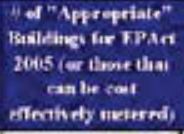 } & \multicolumn{2}{|c|}{ Standard steters } & \multicolumn{2}{|c|}{ Adraked Blater } & \multicolumn{2}{|r|}{ tand } & \multirow{2}{*}{ 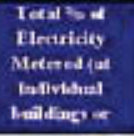 } \\
\hline & & 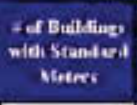 & 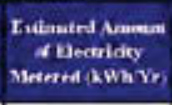 & 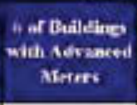 & 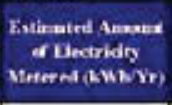 & 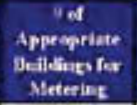 & 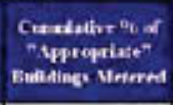 & \\
\hline 2010 Kepert. & 8 & 23 & 6 & $\theta$ & 0 & 20 & TI: & 18.94 \\
\hline 2011 Povent & 62 & 49 & $73,121,449$ & 36 & $51.021,034$ & 85.0 & $137.1 \%$ & 53.3A \\
\hline 2012 Flensed & 64 & 27 & $43,449,949$ & 60 & $98.595,531$ & 870 & 13595 & 6194 \\
\hline 2015 Plasuid & 61 & 27 & $43,449,949$ & 105 & $167,169,158$ & 1320 & $2063 \%$ & Senti \\
\hline
\end{tabular}

1-5h, EISA 2007 Neterine OrNatad Gas tive

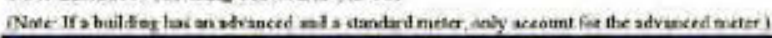

\begin{tabular}{|c|c|c|c|c|c|c|c|c|}
\hline \multirow[b]{2}{*}{ Fiteal vear } & \multirow{2}{*}{ 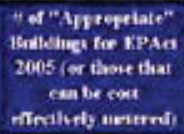 } & \multicolumn{2}{|c|}{ Staulard Miters } & \multicolumn{2}{|c|}{ Adyaced Mecteri } & \multicolumn{2}{|c|}{ Iast } & \multirow{2}{*}{ 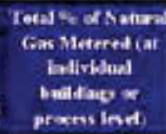 } \\
\hline & & $\begin{array}{l}\text { Act Builinger } \\
\text { with Standard } \\
\text { Mrems }\end{array}$ & 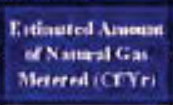 & $\begin{array}{l}\text { of of Butilines } \\
\text { with terenced } \\
\text { Miners }\end{array}$ & 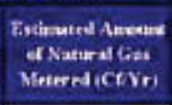 & 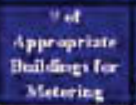 & 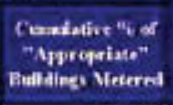 & \\
\hline 2010 Pepent & 20 & 20 & a & 6 & 0 & 200 & $1000 \mathrm{~A}$ & 160 ins \\
\hline 2011 Isport & 15 & 19 & $29,762,076$ &  & 0 & 192 & 10006 & 160.946 \\
\hline 2012 Flatasd & 20 & 210 & $36,200,800$ & 6 & 0 & 20,9 & 10002 & 1668940 \\
\hline 2013 Farrod & 21 & 21 & 31.800,-000 & $\theta$ & 0 & 21.9 & 10000 & 166019 \\
\hline Lo14 Flased & 21 & 21 & $31,800,000$ & $\theta$ & 0 & 21.0 & $1000 \mathrm{~s}$ & $1063^{4}$ \\
\hline 2015 Planed & 21 & 21 & 31.800 .000 & $\theta$ & 0 & 21.0 & 10000: & 160.94 \\
\hline
\end{tabular}

15e. EISA 2007 Mevering Or Stean Ulse

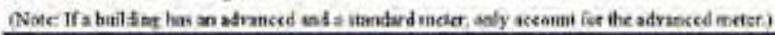

\begin{tabular}{|c|c|c|c|c|c|c|c|c|}
\hline \multirow[b]{2}{*}{ Eliteal Yex: } & \multirow{2}{*}{ 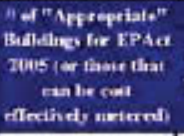 } & \multicolumn{2}{|c|}{ Standured Moters } & \multicolumn{2}{|c|}{ Advalaced Meters } & \multicolumn{2}{|c|}{ Iaral } & \multirow{2}{*}{ 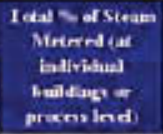 } \\
\hline & & $\begin{array}{l}\text { Fut Buillings } \\
\text { winh Stand ard } \\
\text { Mieters }\end{array}$ & 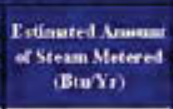 & $\begin{array}{l}\text { a of Loild lives } \\
\text { widh Alvaneted } \\
\text { Meters }\end{array}$ & 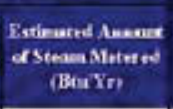 & 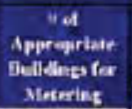 & 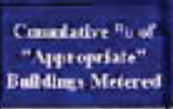 & \\
\hline 2010 Eecport. & a & o & 0 & 0 & o & 00 & scavio & $0.50 \%$ \\
\hline 2011 Deport & c & 0 & 0 & 0 & 면 & 00 & exrvol & 0.59, \\
\hline 2012 Thand & a & a & 0 & 0 & 0 & 0.0 & acrvo & $0,0 \mathrm{~s}$ \\
\hline 2013 Framed & a & a & 0 & 0 & 0 & og & Arrvan & $0 \mathrm{sen}$ \\
\hline कola Ffanned & 9 & 0 & 6 & 0 & 0 & $B 0$ & $\exists$ ando & $a x_{2}$ \\
\hline 2015 Rambed & G & 0 & 0 & 0 & 0 & $0 \mathrm{D}$ & HDTVN & $0,0 \%$ \\
\hline
\end{tabular}


FY 2011 Energy Management Data Report

\begin{tabular}{|c|c|c|c|}
\hline Progenat & Department of kincry & Prepared by: & Erantl, Foweun \\
\hline Sitet & Ielae Surienal Labeentor? & Fhanet & $(205) 5261513$ \\
\hline Fiseal Yeart & $\overline{3011}$ & Datet & 1762011 \\
\hline
\end{tabular}

Recaircuisuitst Sec table

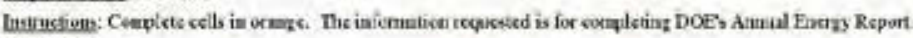

Sorse: Site

15d. DOE O 436.1 \& 5SPP Metering of Chilled Water Vy

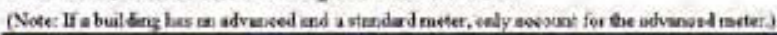

\begin{tabular}{|c|c|c|c|c|c|c|c|c|}
\hline \multirow[b]{2}{*}{ Firal vear } & \multirow{2}{*}{ 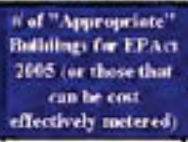 } & \multicolumn{2}{|c|}{ Stasiard Merteri } & \multicolumn{2}{|c|}{ Advanced Meteri } & \multicolumn{2}{|c|}{ Tasl } & \multirow{2}{*}{ 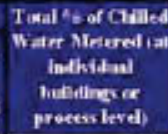 } \\
\hline & & $\begin{array}{l}\text { or Bualdires } \\
\text { widet Standarit } \\
\text { Micters }\end{array}$ & 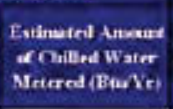 & 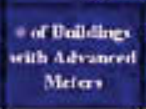 & 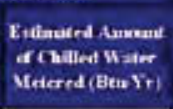 & 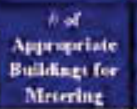 & 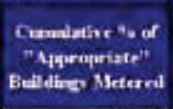 & \\
\hline 3010 Fispert & 0 & 9 & c & 6) & 요 & 0.0 & aDFV: & $0.0 \mathrm{~S}$ \\
\hline 2011 Fepert & 0 & 0 & c) & $\theta$ & 9 & 0.0 & तDIViol & 900 \\
\hline $20121 \%$ manct & 0 & 0 & a & a & 0 & 00 & hDIV: & $O \mathrm{OA}_{4}$ \\
\hline 2013 Pliezicl & 0 & 0 & 0 & 0 & a & 0.0 & horvo & achis \\
\hline 2014 Planel & ? & 0 & 9 & c) & 요 & 0,0 & eDrval & $a e^{2}$ \\
\hline 2015 Thane ! & 0 & 0 & a & बी & 9 & 0.0 & hDIVO: & $00 \%$ \\
\hline
\end{tabular}

1.5e. Weter Manageniese Beat Practice Metering OrWatex tisr

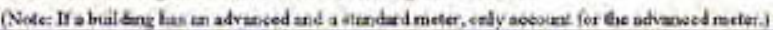

\begin{tabular}{|c|c|c|c|c|c|c|c|c|}
\hline \multirow[b]{2}{*}{ Fitcralliest } & \multirow{2}{*}{ 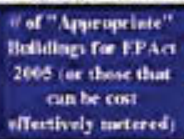 } & \multicolumn{2}{|c|}{ 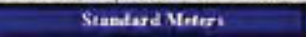 } & \multicolumn{2}{|c|}{ Advared Meter: } & \multicolumn{2}{|c|}{ Ians } & \multirow{2}{*}{ 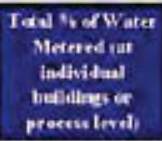 } \\
\hline & & 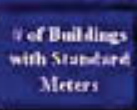 & 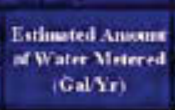 & 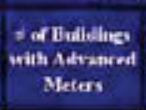 & 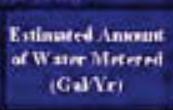 & 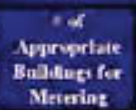 & $\begin{array}{l}\text { Candative is of } \\
\text { "Mifurapriate" } \\
\text { Beildires Mletered }\end{array}$ & \\
\hline 2010 Ecpert & $\mathrm{TIm}$ & 19 & 0 & 6 & a) & 190 & NALOD & $140^{\mathrm{a}} \mathrm{i}$ \\
\hline 2011 Dapont & 16 & 76 & $+0,000.000$ & 0 & 0 & 160 & 100.98 & $45 \mathrm{sin}$ \\
\hline 2012 Plaze! & TuB & 17 & $+0,000,000$ & 0 & 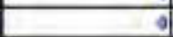 & $17 g$ & WVALUE & $43^{\circ}$ \\
\hline 2013 Flaxac & IBID & 18 & $42.500,000$ & 6 & a & 180 & WALtE & $539 \%$ \\
\hline 2014 Flaned & TIDD & 18 & +5,900,9000 & 0 & $\theta$ & 180 & NVALUD: & $5 \Delta^{2}$ \\
\hline 2015 Plinencl & $17 \mathrm{II}$ & t8 & $45, a 60.000$ & 0 & a & 180 & WYALUE & $50 \%$ \\
\hline
\end{tabular}




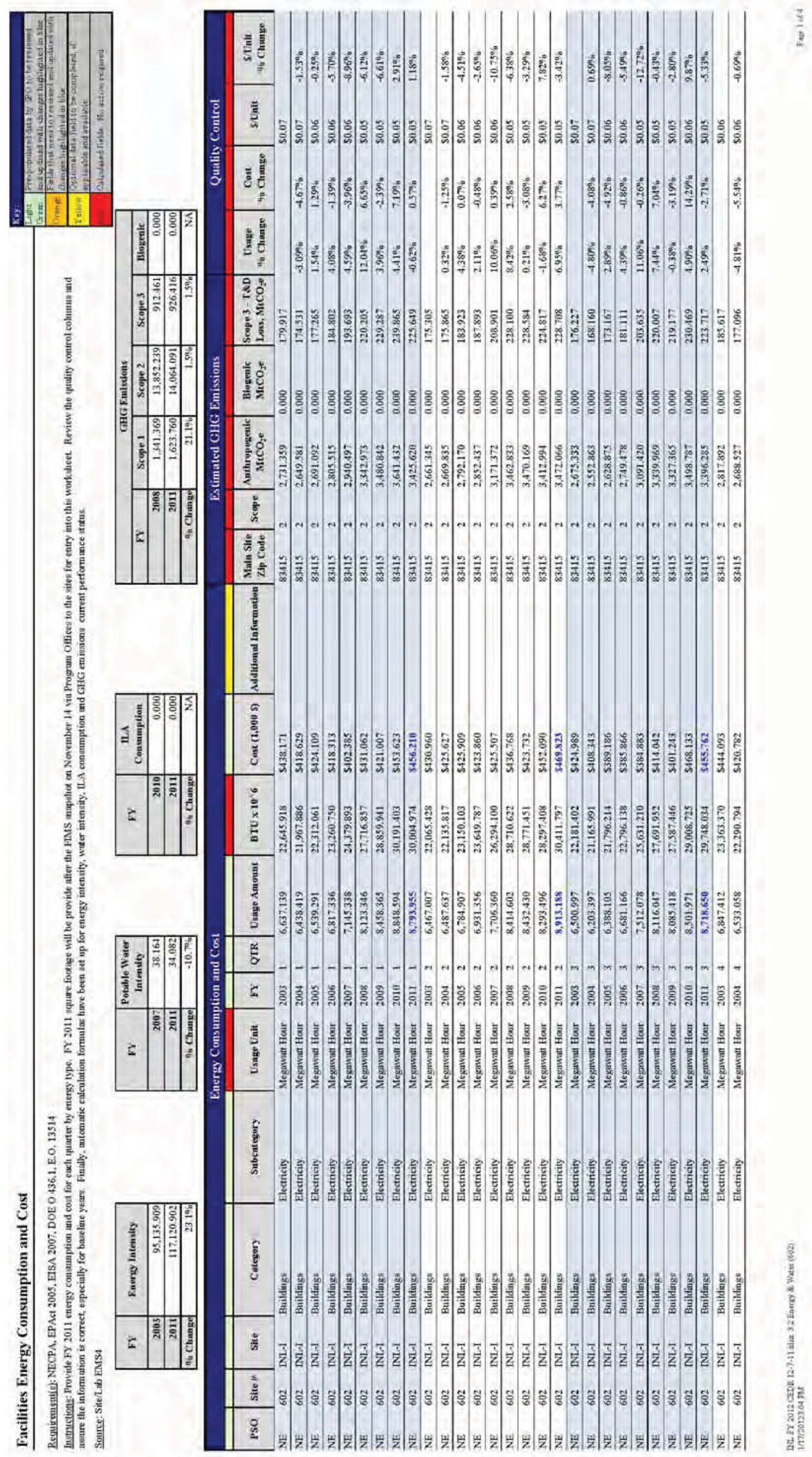




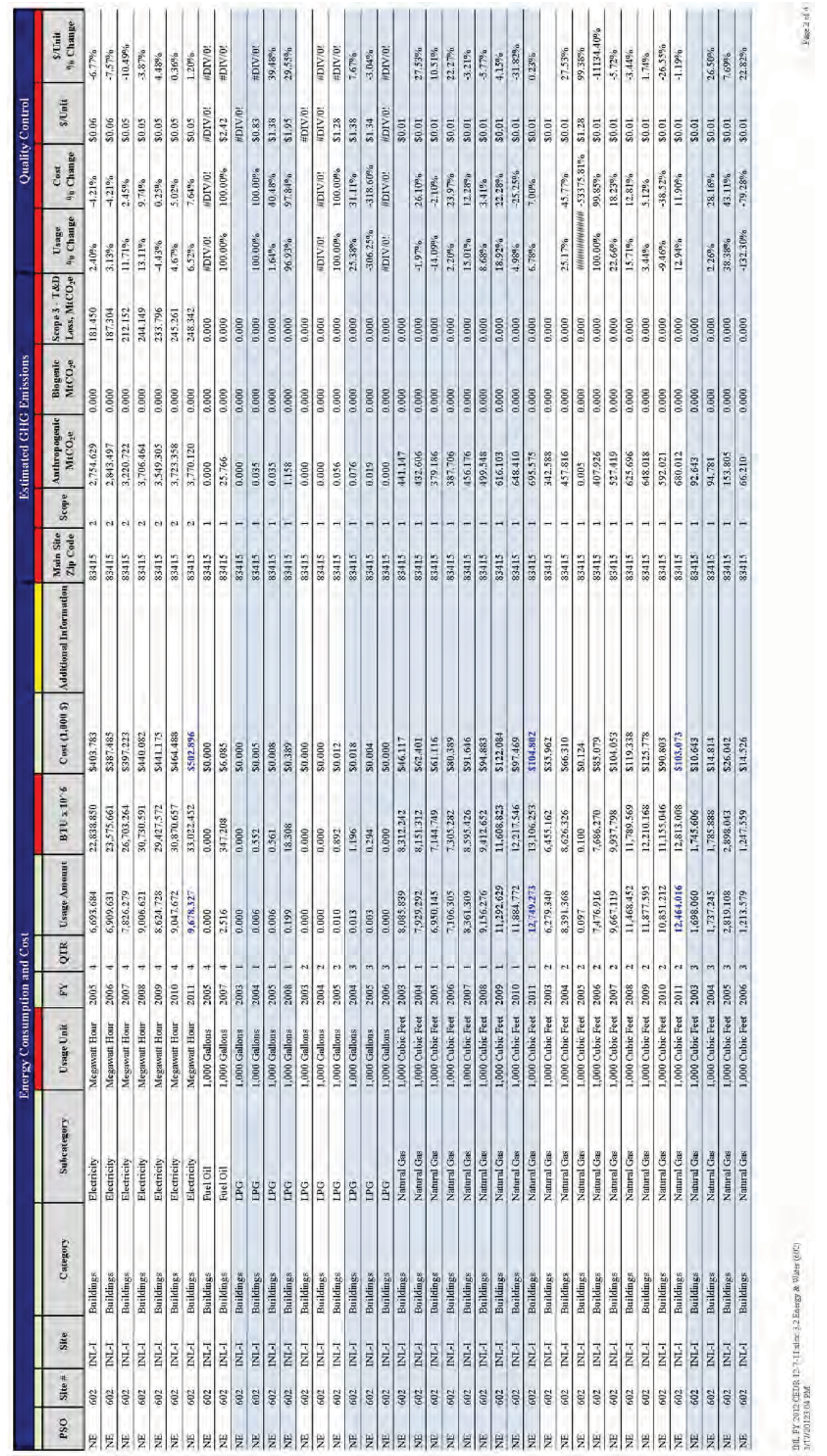



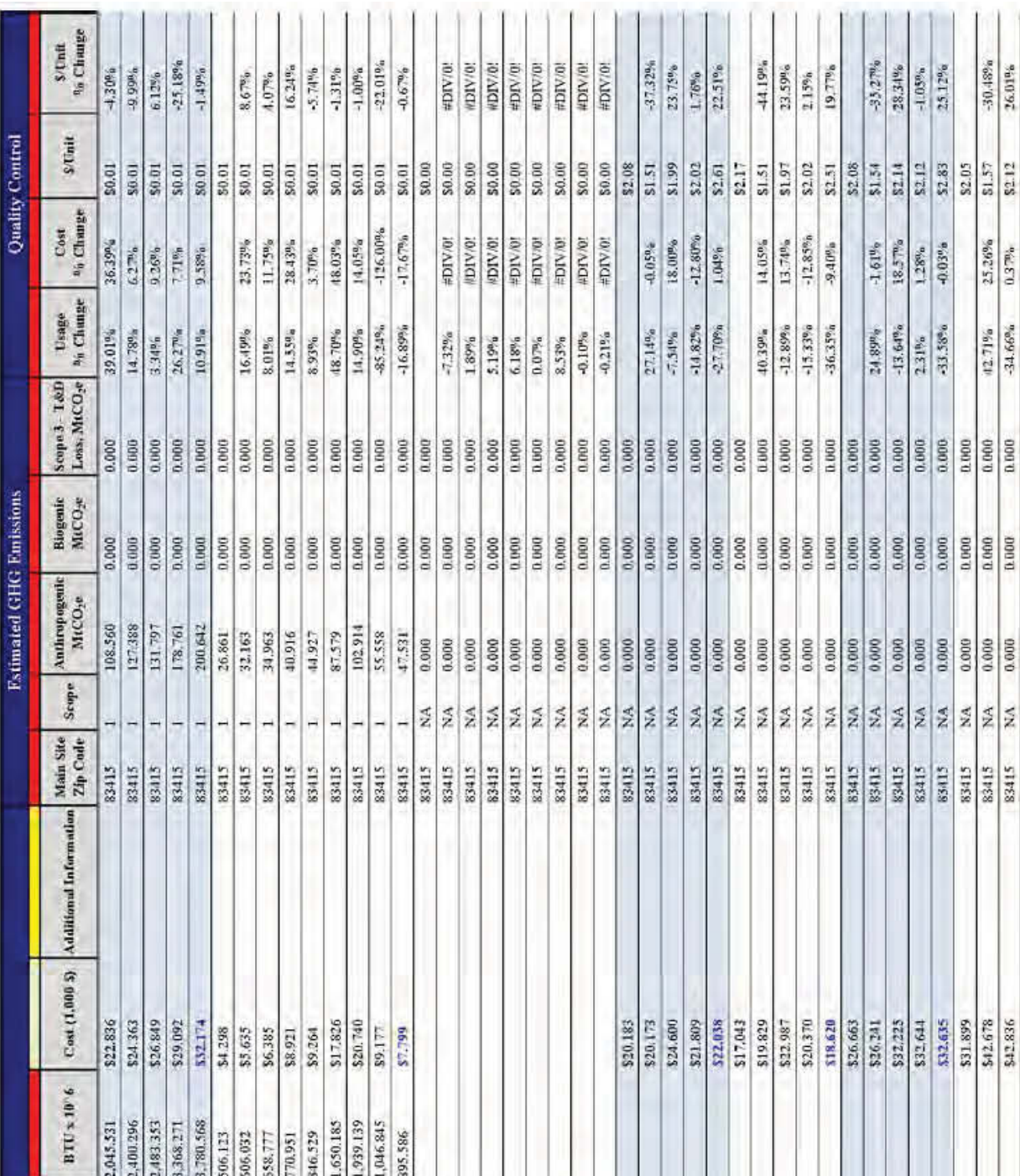

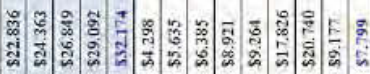

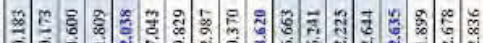

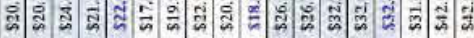

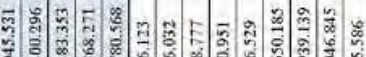

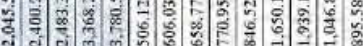

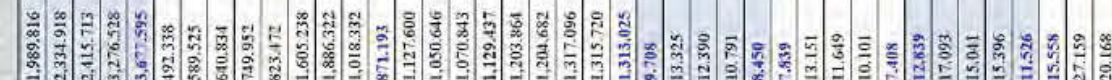

龸

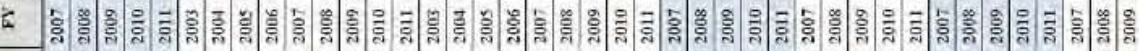

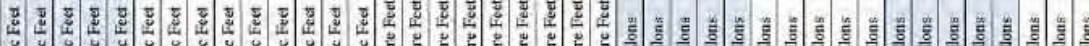

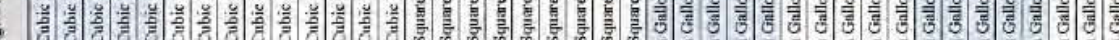

1

(1)



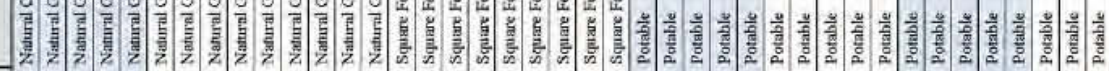

f

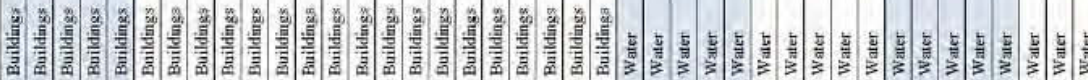

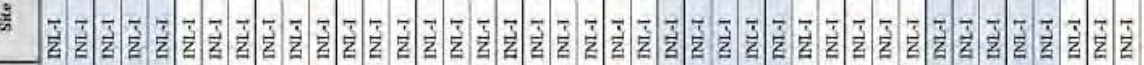
章

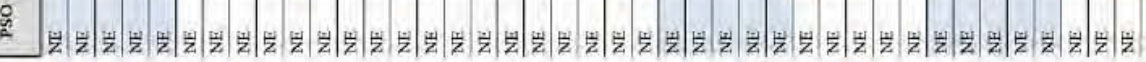




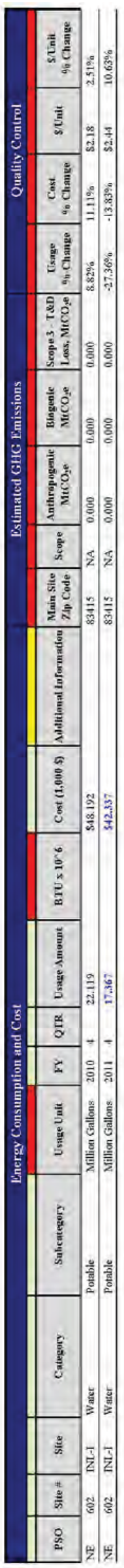

6 


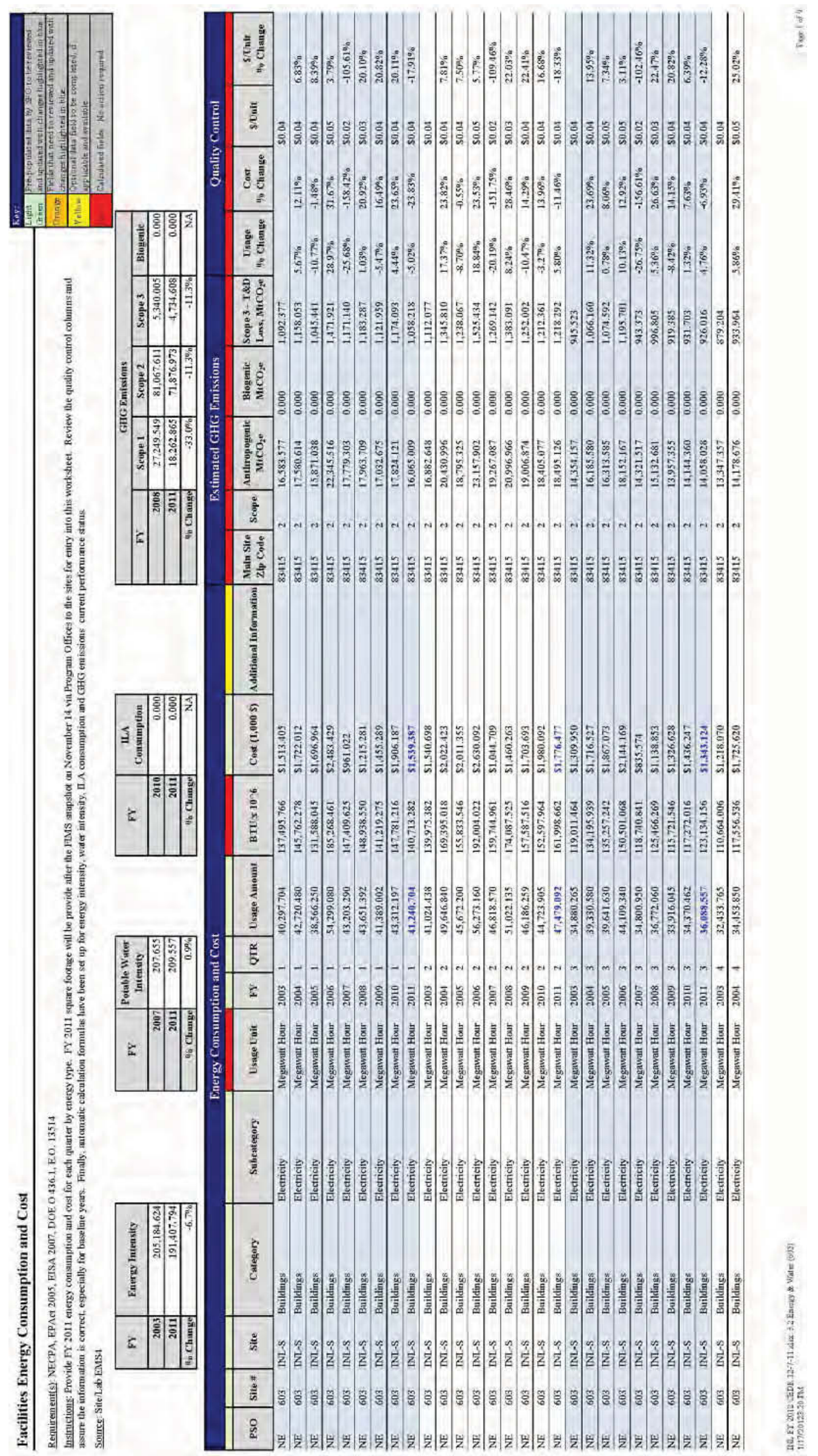




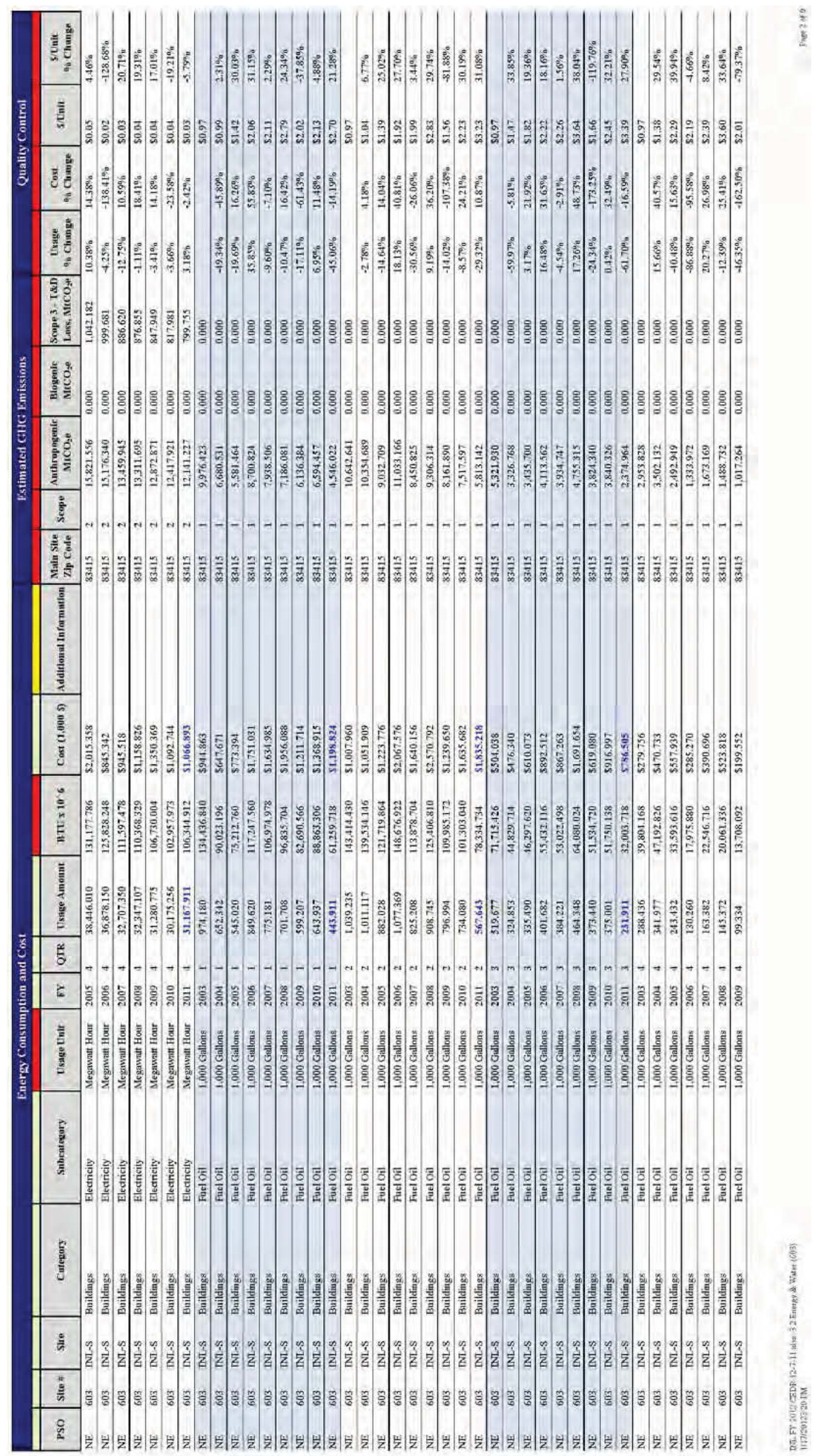




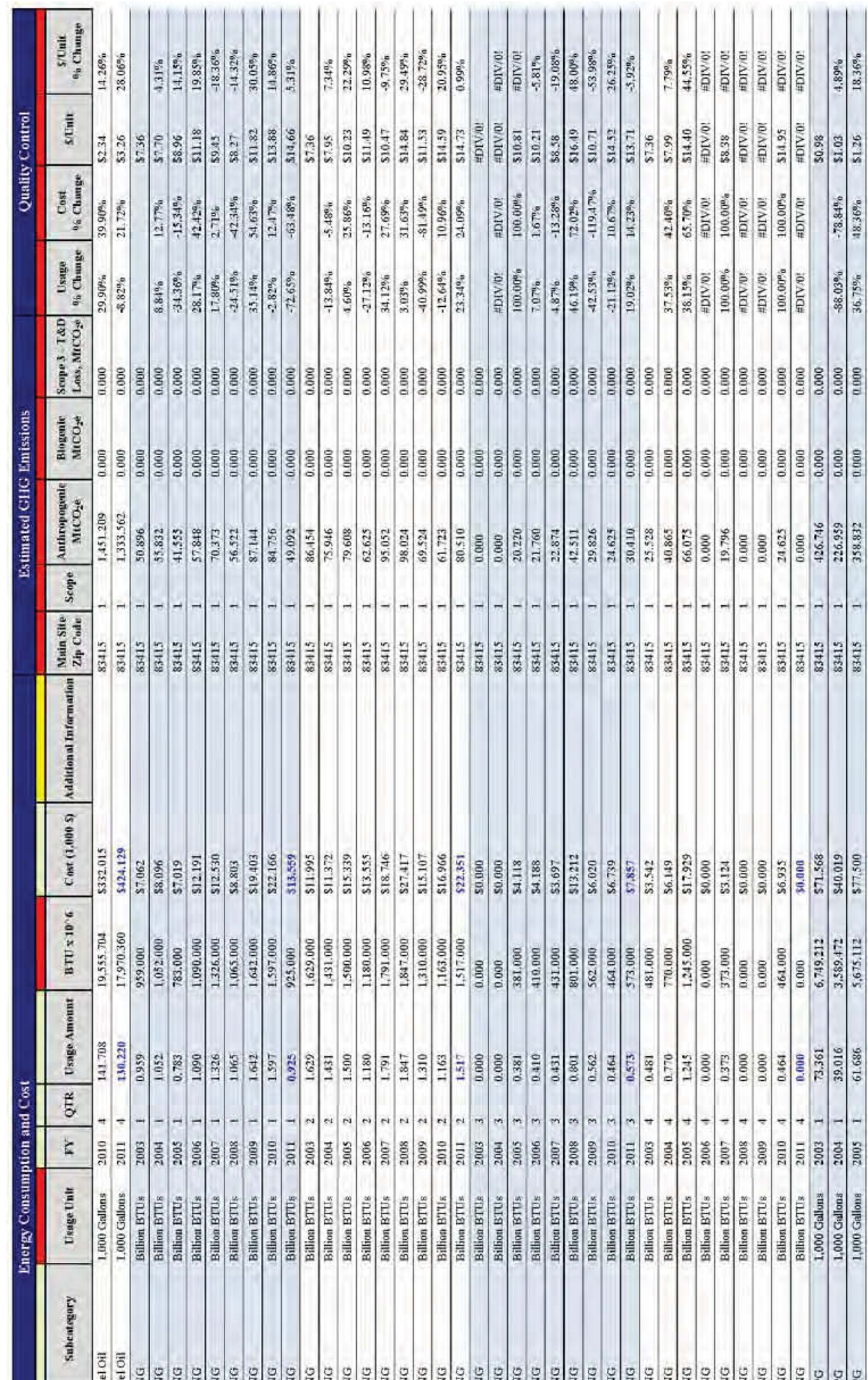

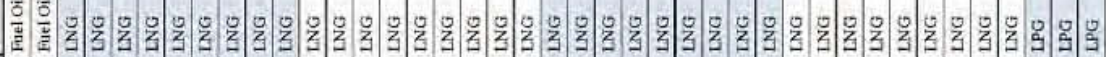

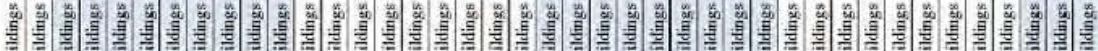

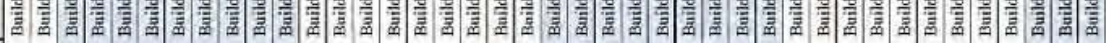

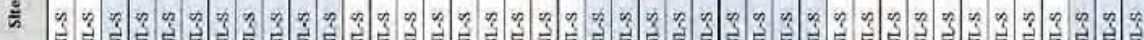

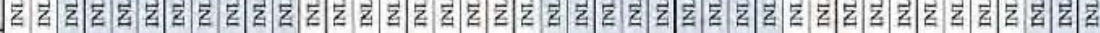
竞

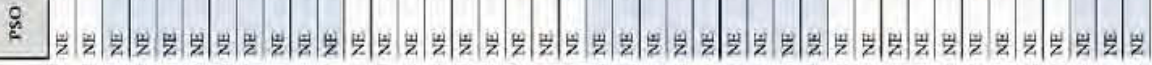




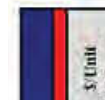

(1.

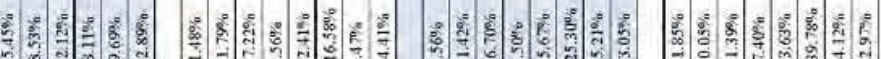

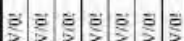

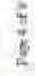

ह

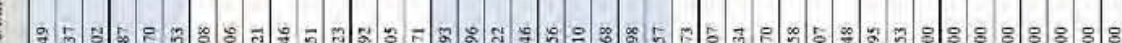
不

i

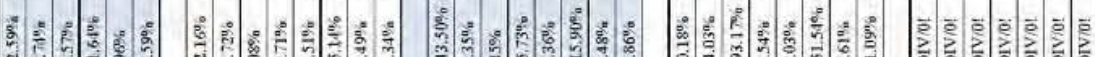

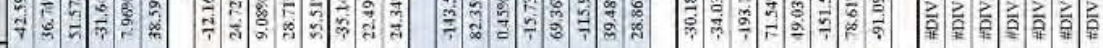

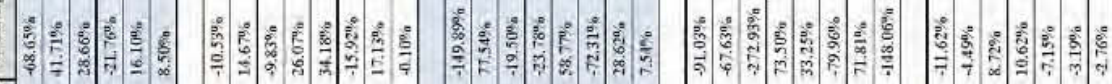

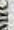

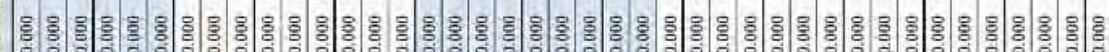

(8)

훙

눈.

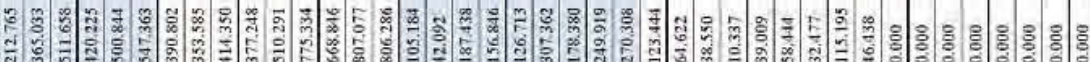

悹

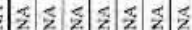

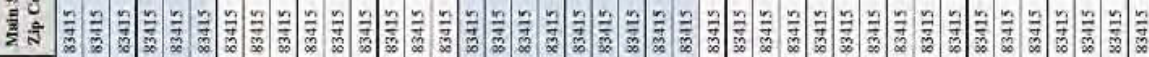

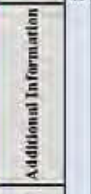

ต

드음을

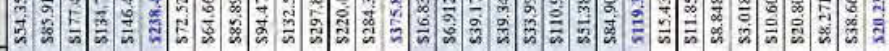

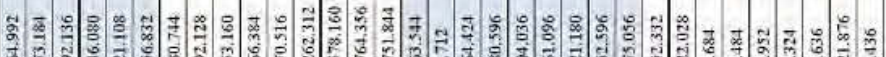

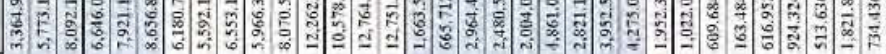

音

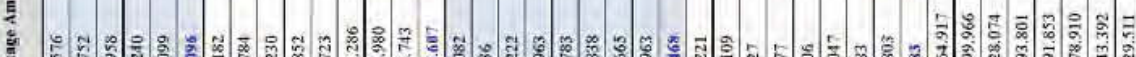
궁

है

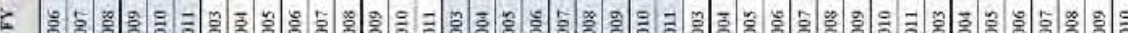

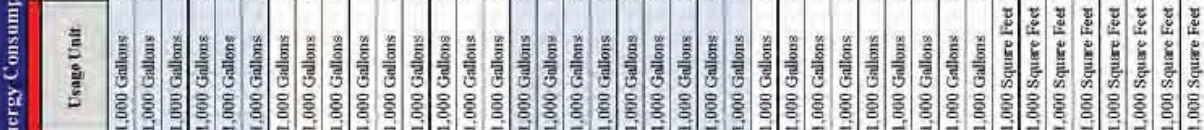

部

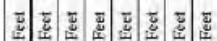

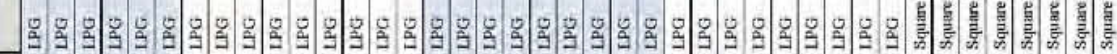

है

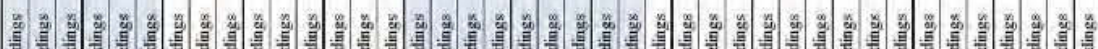

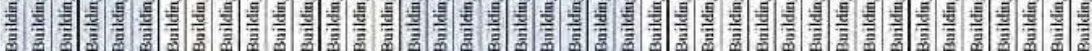

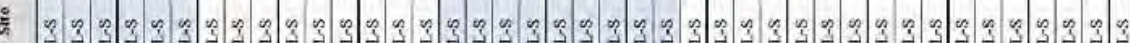

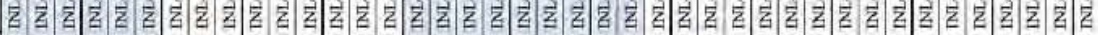
壱

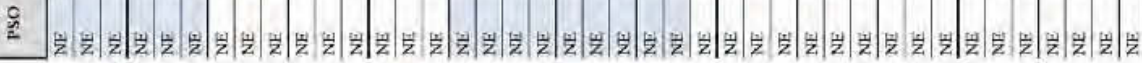









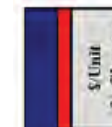

要 (1)

(3)

(1)

10

श्:

in

is

흥 흥 형

害:

章

产

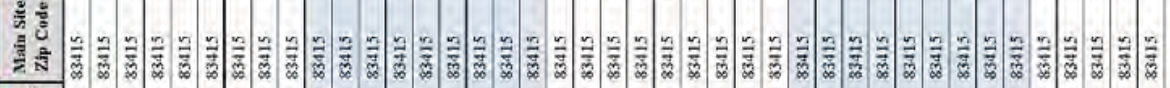

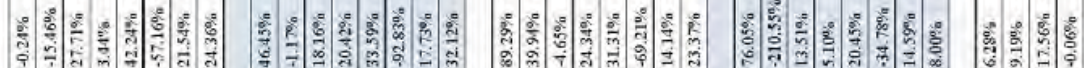

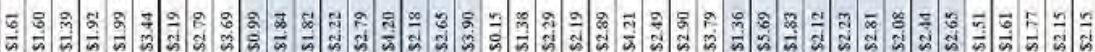

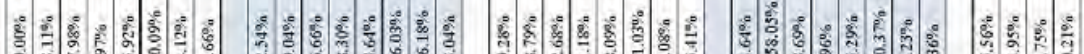

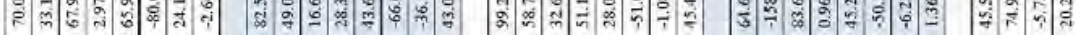

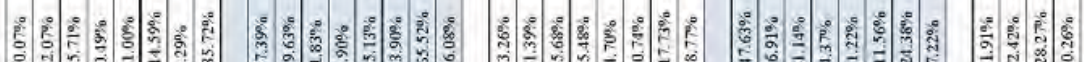



은

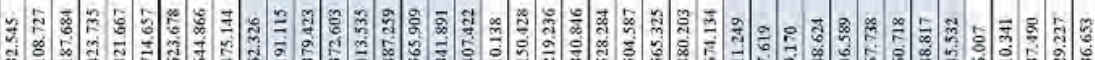

西

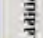

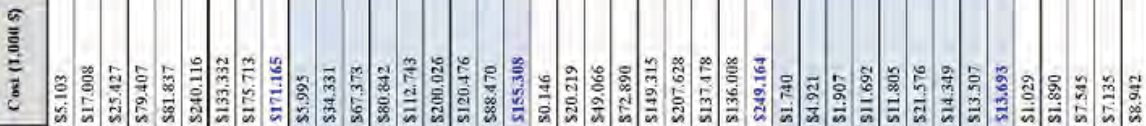

:

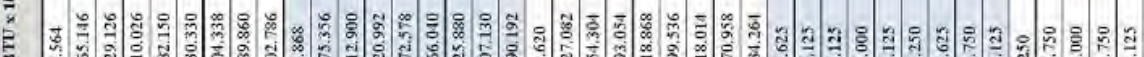

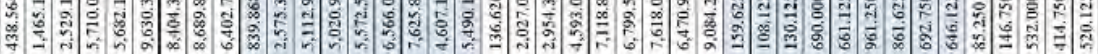

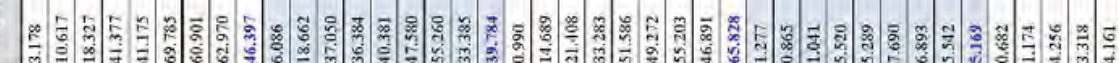



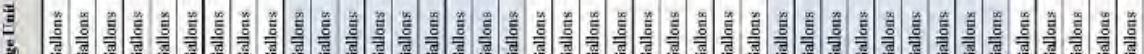


害:

tis

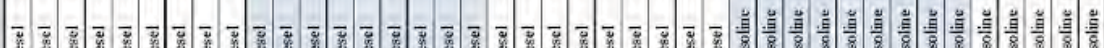

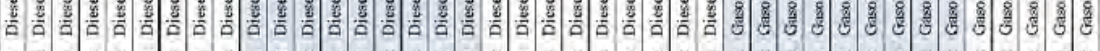

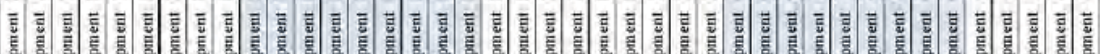

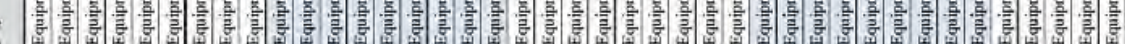

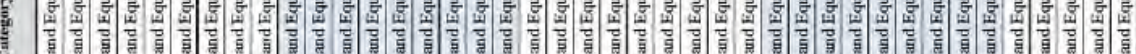

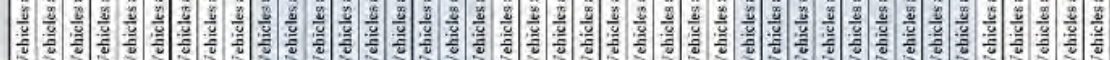

के

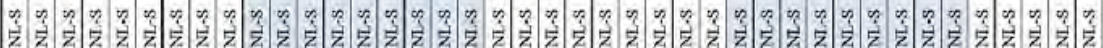

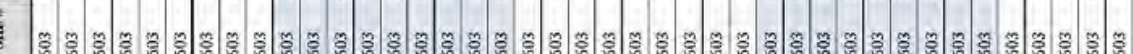

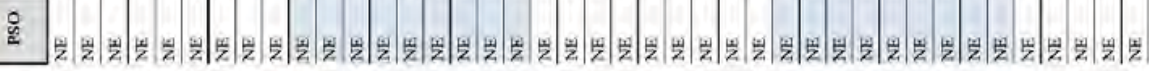




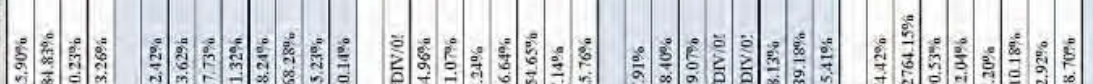



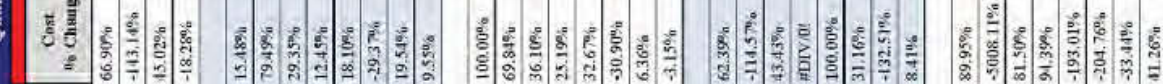

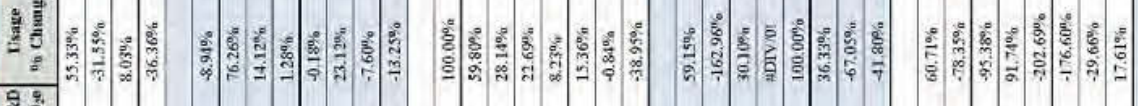

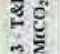

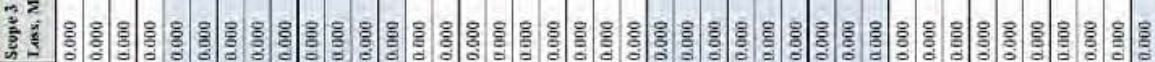

है:

흥

in

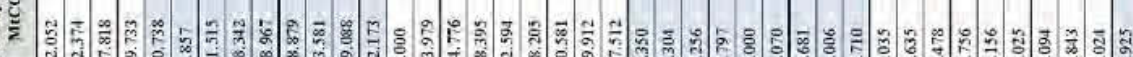

嘉

कै हैं

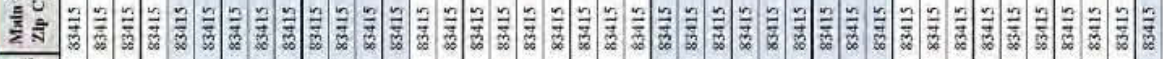

(

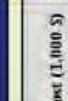

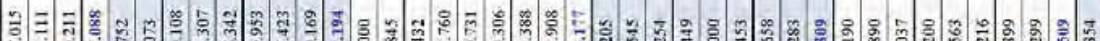

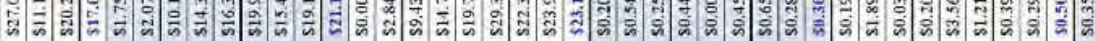

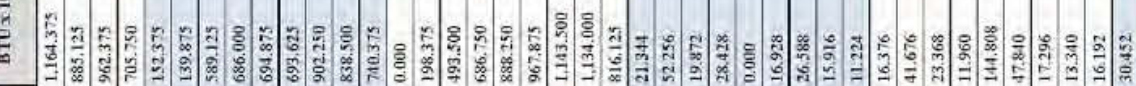

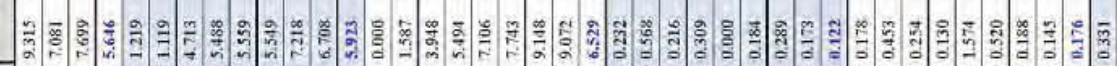
है

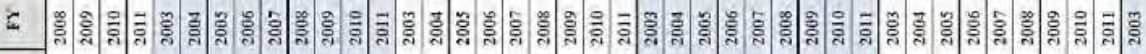

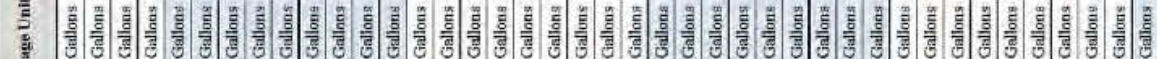
웅

恶

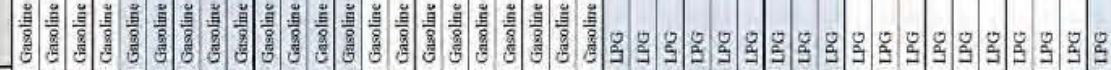

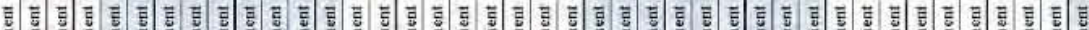
4 (n)

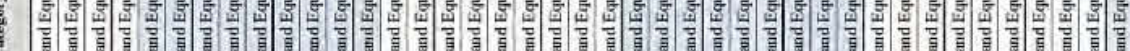



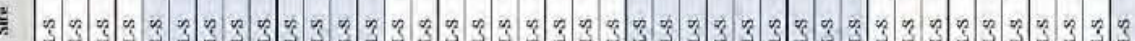

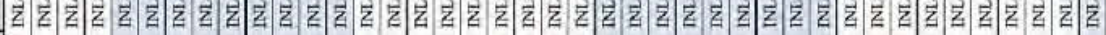
竞:

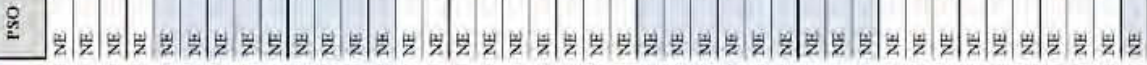




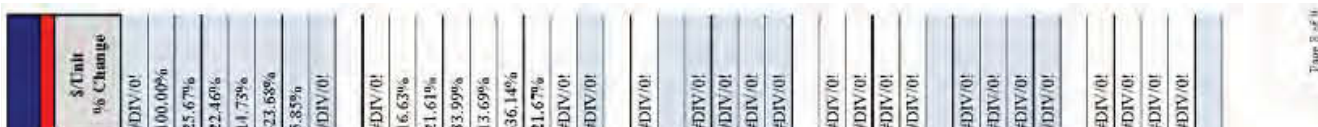

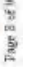

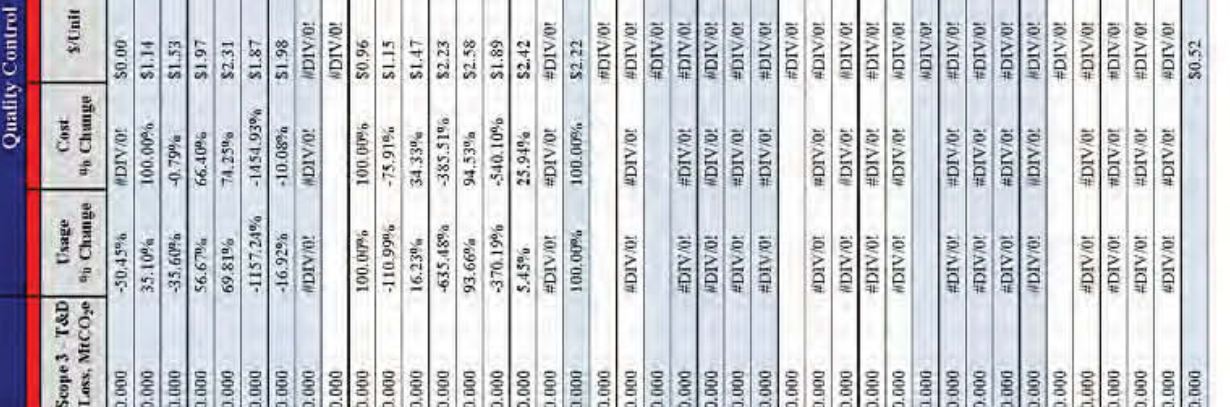

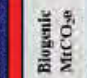
훙 훙 数

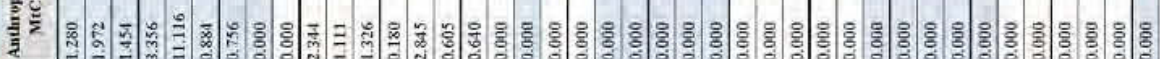
部

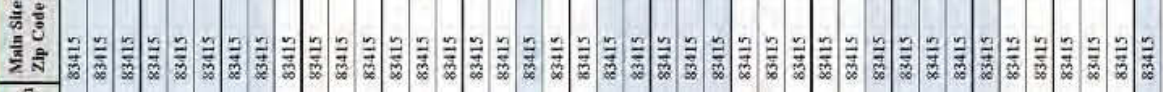
.

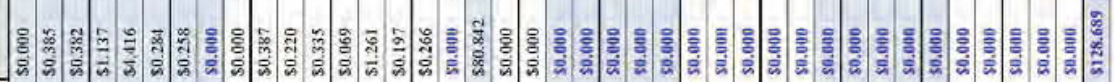

$\underline{-1}$

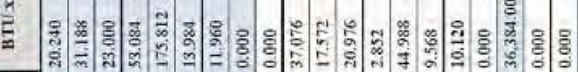

i

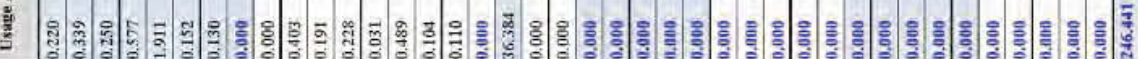
है

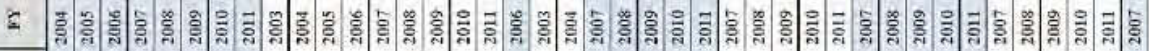

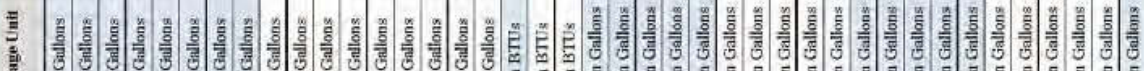
1

(1)

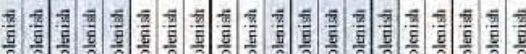

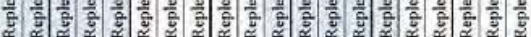

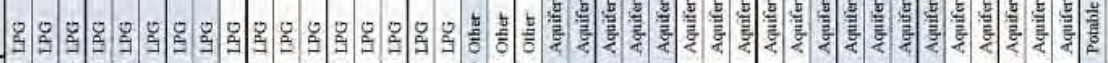

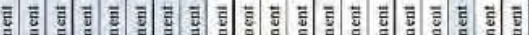

c.

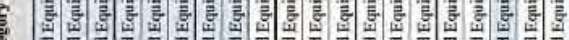

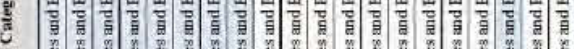

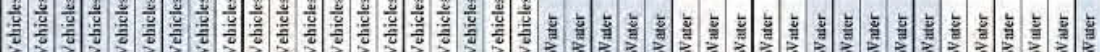

-

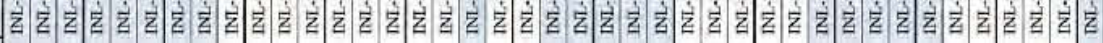
站

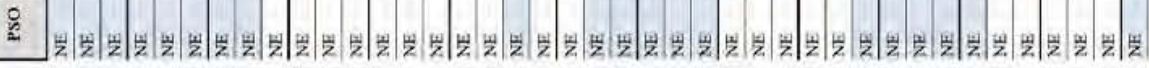









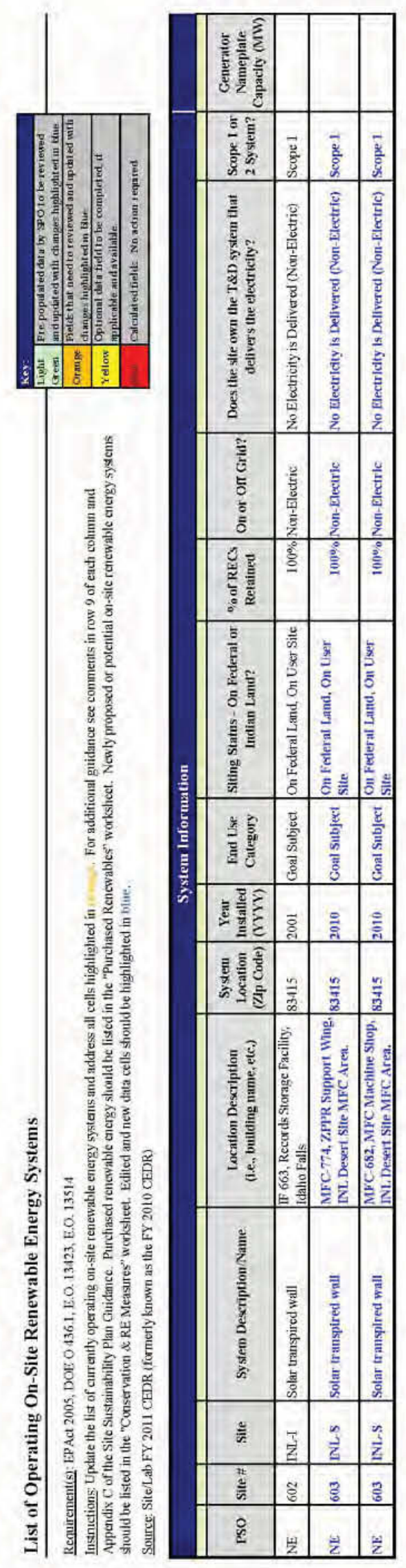

F 


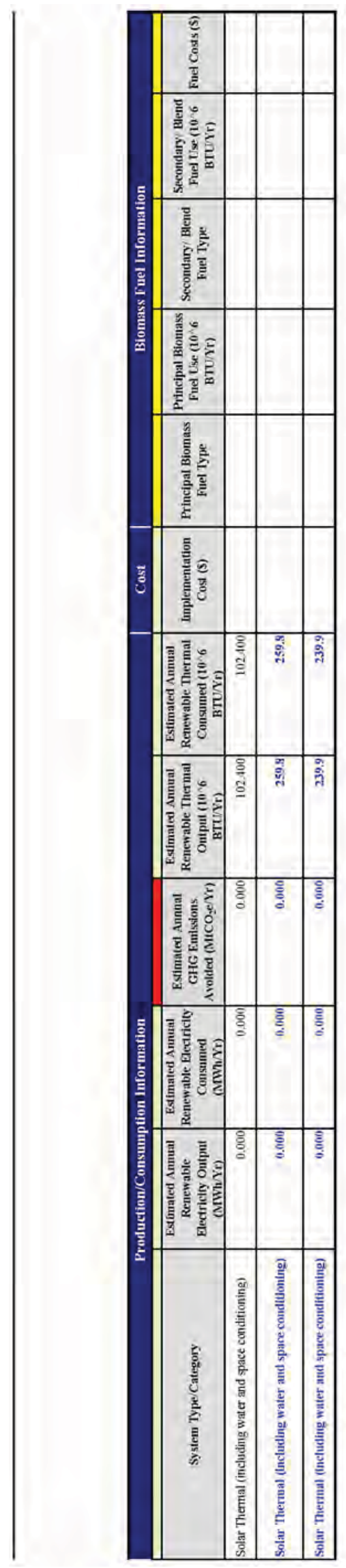




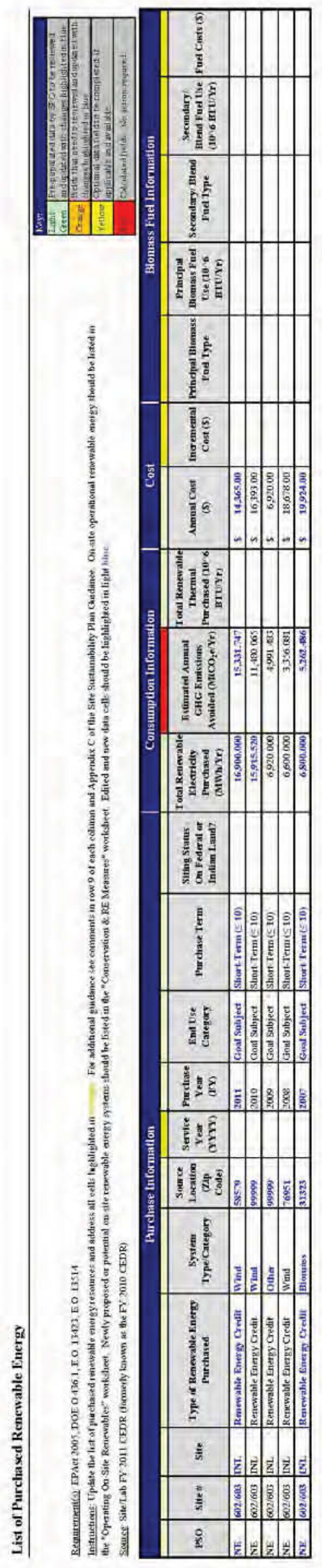




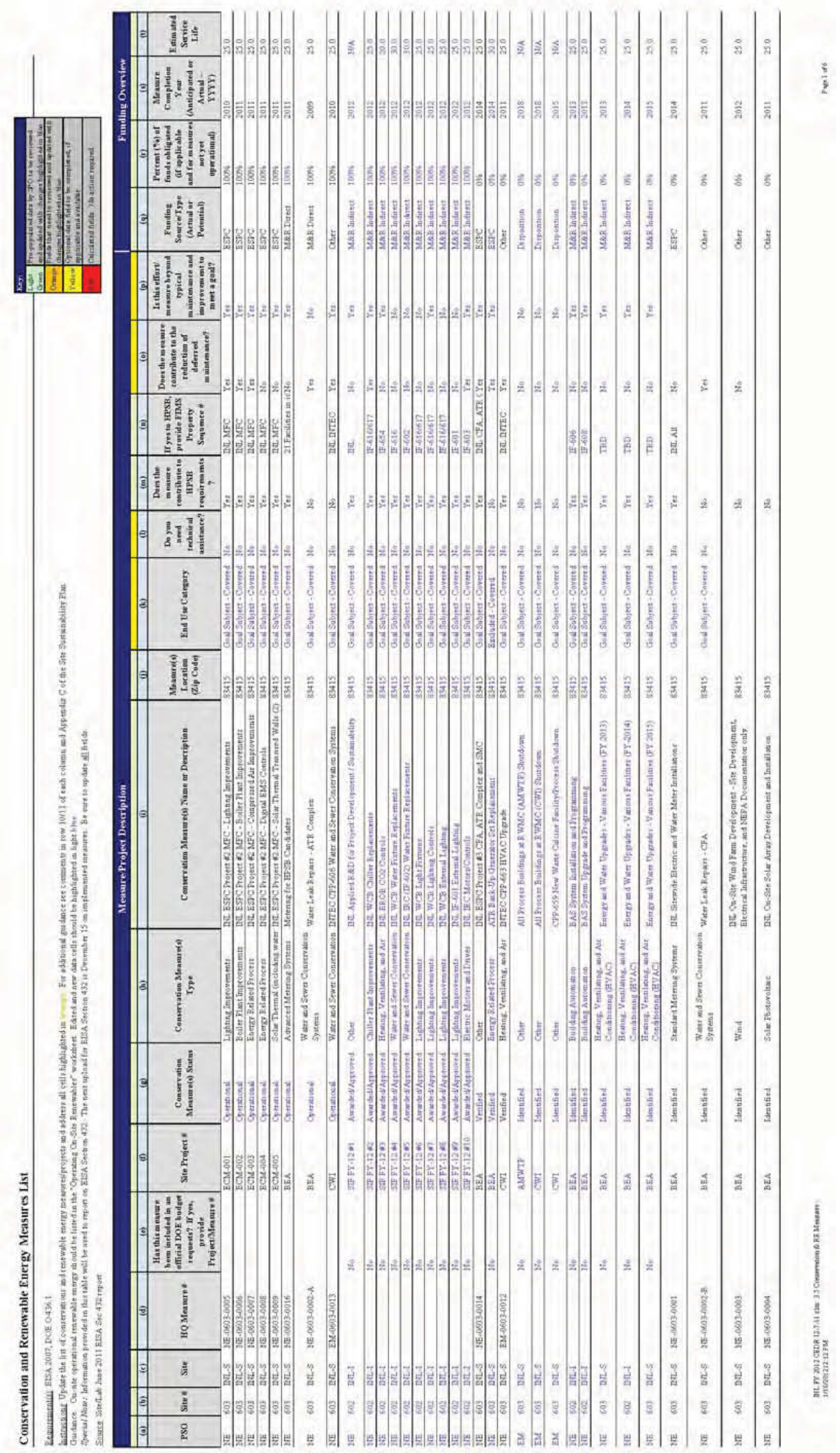




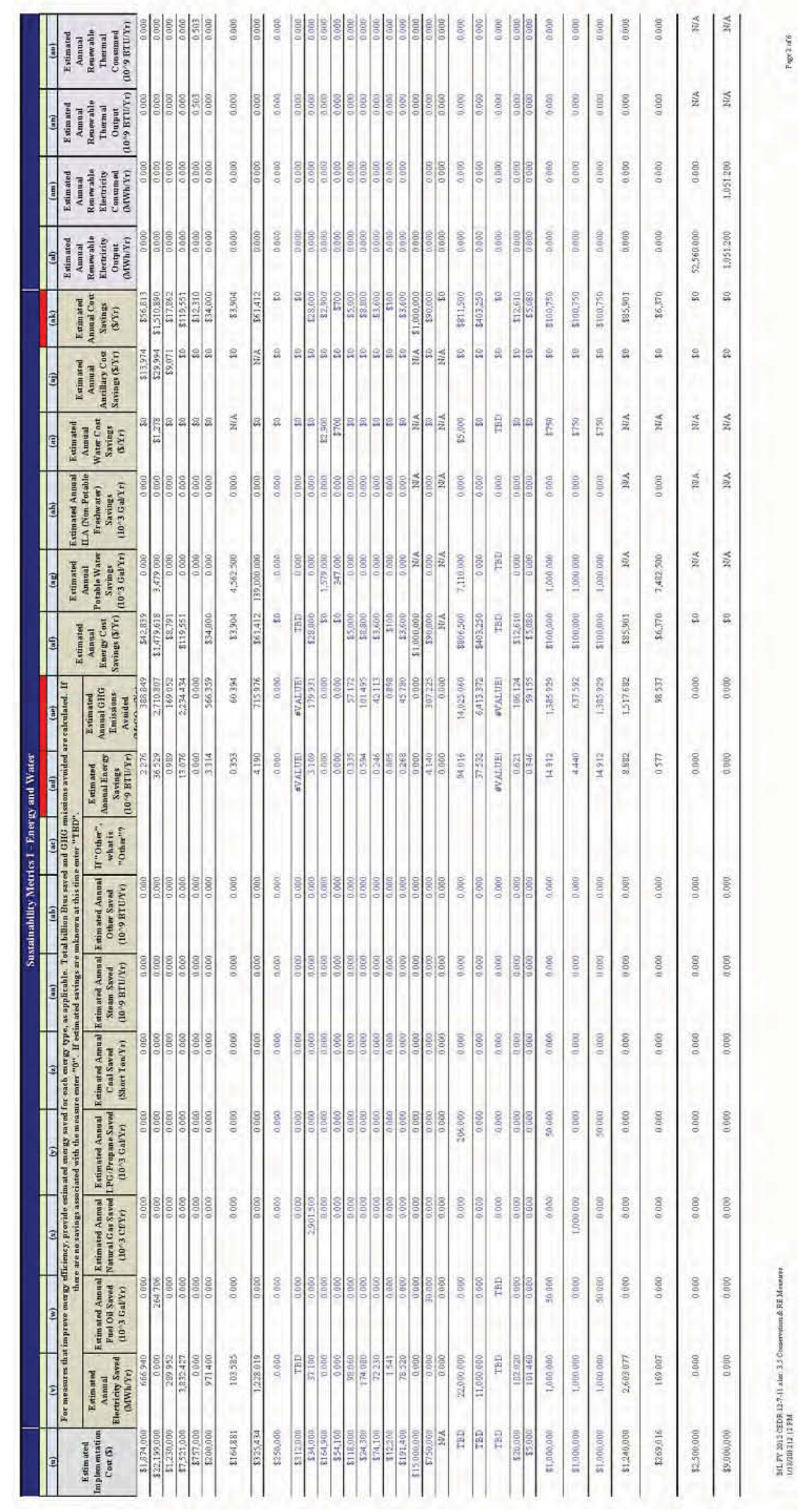




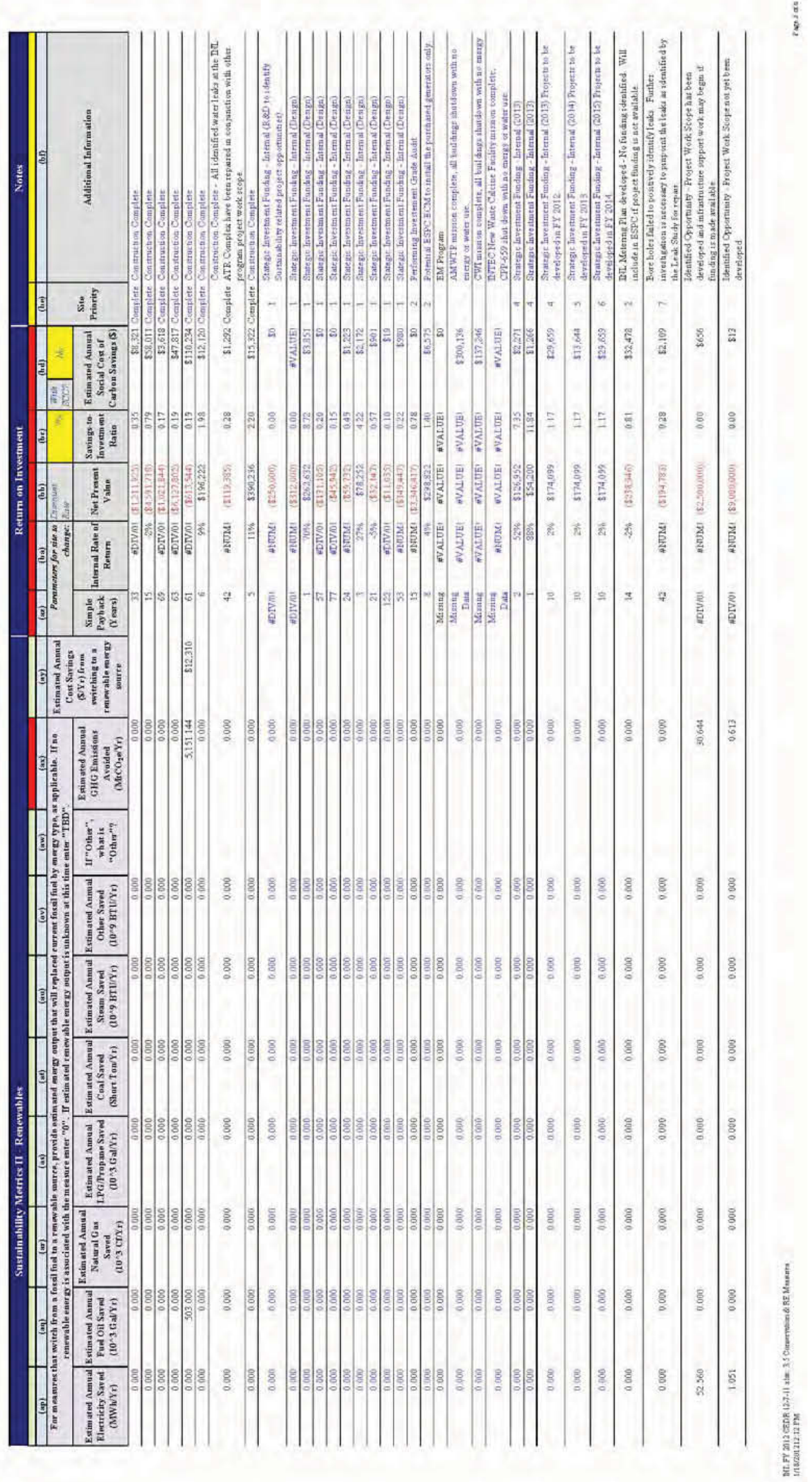




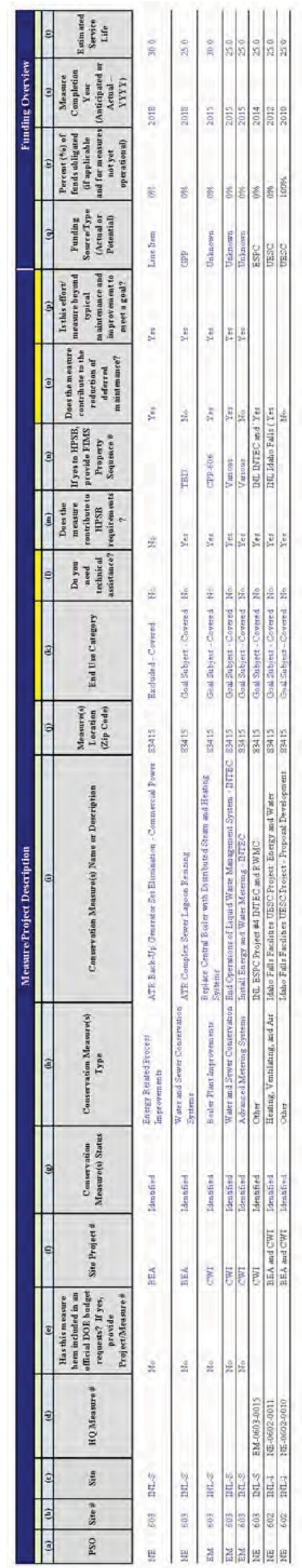









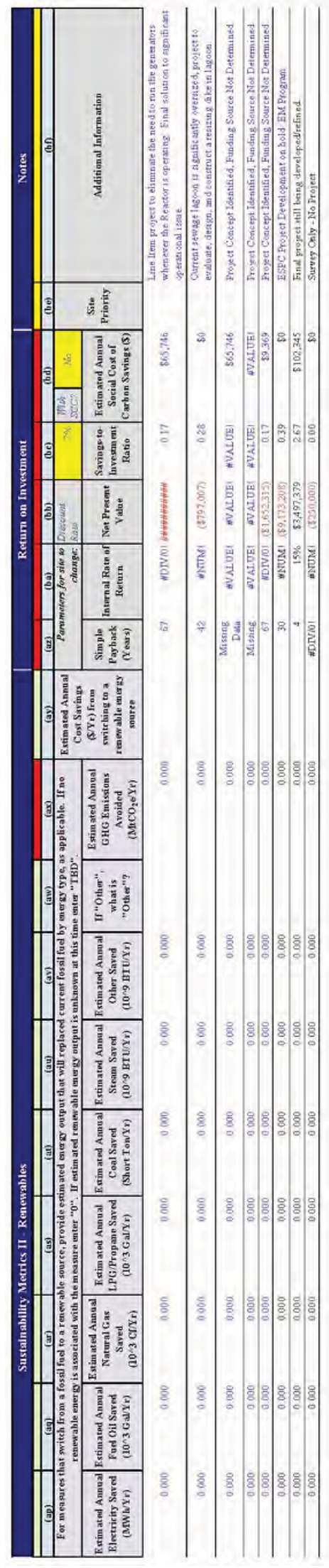




\section{Source Energy Savings Credit}

\section{Reoutrument(s)' F, S 13123}

Instructions: Optional ecmplete the tables below for projects that mucrease site encrgy use but save souroe energy. For additional guidance see hatp iwww eere energy gov/fenp pafs sec 562 f $v 20$ guidance pdf. Edited and new data cells should be hightighted in light blue.

Sounce: Sitelate

EPaC'T Goal Subject Buildings

\begin{tabular}{|c|c|c|c|}
\hline \multirow{2}{*}{$\begin{array}{l}\text { Naue of Project Suving Source Kuerzy } \\
\text { in FY } 2011 \text { (insert additional rows as } \\
\text { necessury) }\end{array}$} & $\begin{array}{c}\text { Anmual Site Energy } \\
\text { Inerease with the Project }\end{array}$ & $\begin{array}{l}\text { Annual Source Energy } \\
\text { Saved with the Projeet }\end{array}$ & $\begin{array}{c}\text { Adjustment to Annual } \\
\text { Site Energy }\end{array}$ \\
\hline & $\left(10^{4} 6\right.$ BTL/Yr) & $\left(10^{\circ} 6 \mathrm{BTU} / \mathrm{Yr}\right)$ & $(10 \times 6 \mathrm{BTU} / \mathrm{Yr})$ \\
\hline Project No: 1 & 0,0 & 10.0 & 0.0 \\
\hline Project No 2 & (0,0) & 0.0 & 12.0 \\
\hline Projact Xo 3 & 0.0 & 0.0 & 0.0 \\
\hline Tolals & 0,0 & 170 & $\overline{B 0}$ \\
\hline
\end{tabular}

EPACT Fxeluded Buildings

\begin{tabular}{|c|c|c|c|}
\hline \multirow{2}{*}{$\begin{array}{l}\text { Name of Project Saving Source Fnergy } \\
\text { in F } 2011 \text { (insert additional rows as } \\
\text { necessary) }\end{array}$} & $\begin{array}{c}\text { Nmual Site Energy } \\
\text { Increase with the Project }\end{array}$ & $\begin{array}{l}\text { Annual Source Energy } \\
\text { Saved with the Project }\end{array}$ & $\begin{array}{l}\text { Adjustmend to Anmual } \\
\text { Site Energy }\end{array}$ \\
\hline & $(10 \% 6 \mathrm{BT} U / \mathrm{Yr})$ & $(10 \% 6 \mathrm{BTU} / \mathrm{Yr})$ & (10/6 BTU/Yr) \\
\hline Project No, 1 & 0.0 & 0.0 & 0,0 \\
\hline Project No. 2 & 0,0 & 0.0 & 0.0 \\
\hline Project No, 3 & 0.0 & 0.0 & 0.0 \\
\hline Iotala & 0.0 & (0.5) & 90 \\
\hline
\end{tabular}




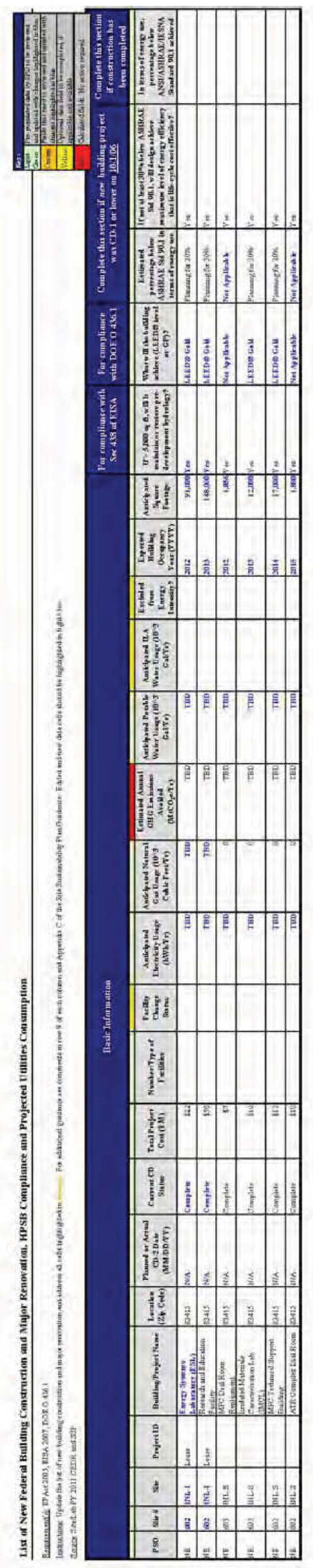




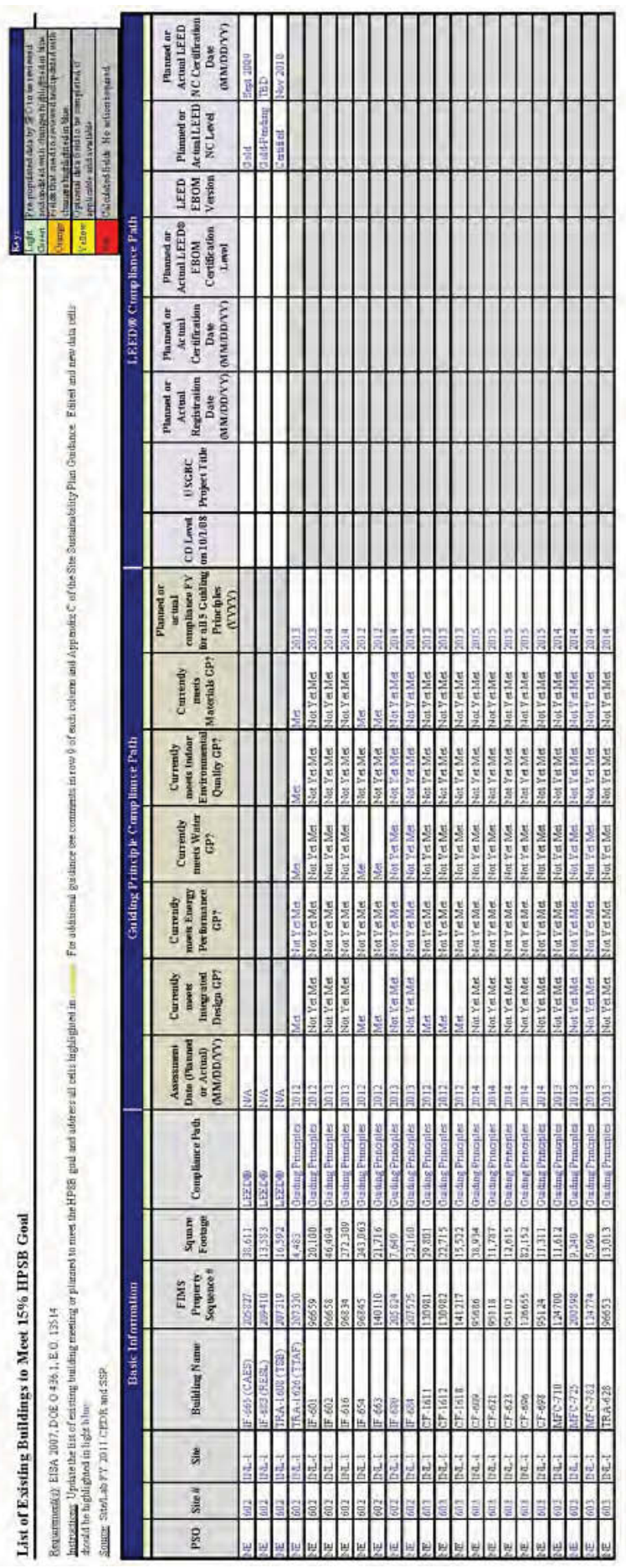

$\frac{5}{2}$ 


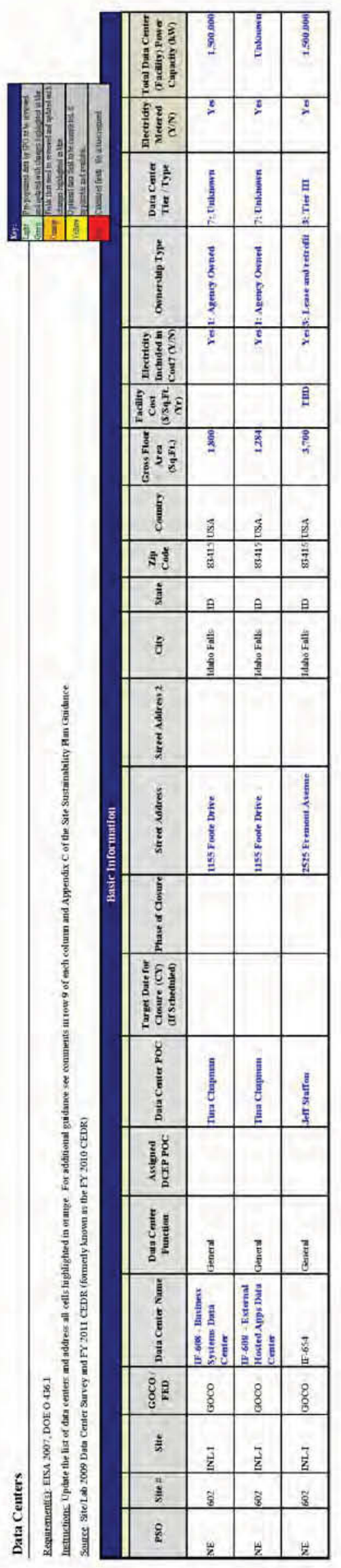




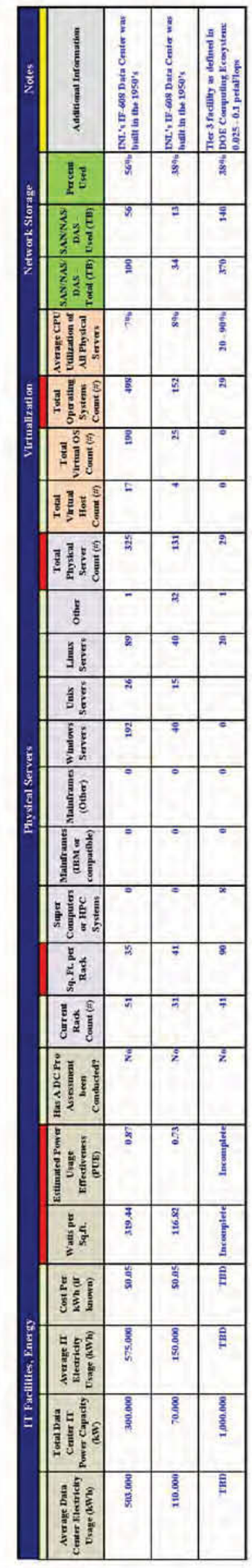




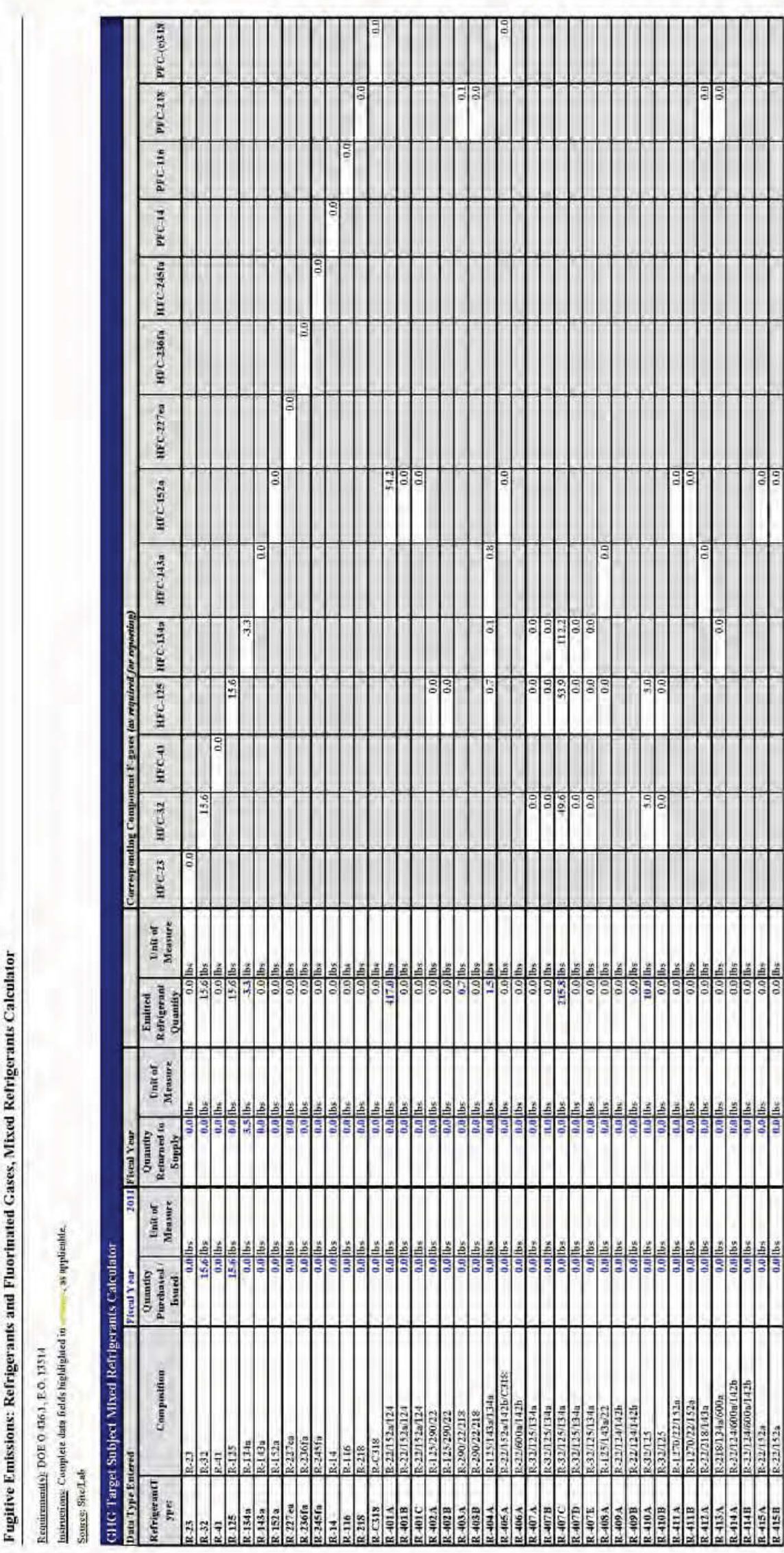

$\frac{5}{5}$ 

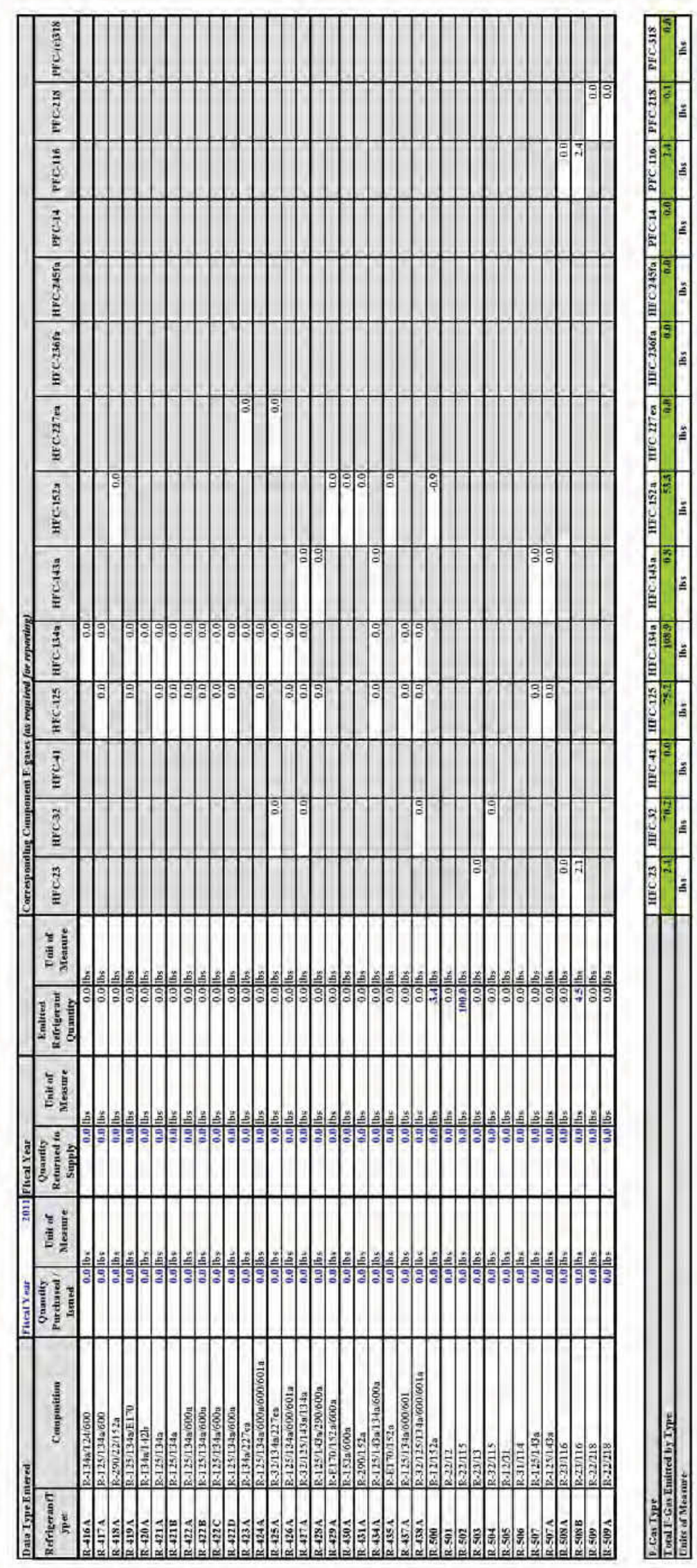

: 


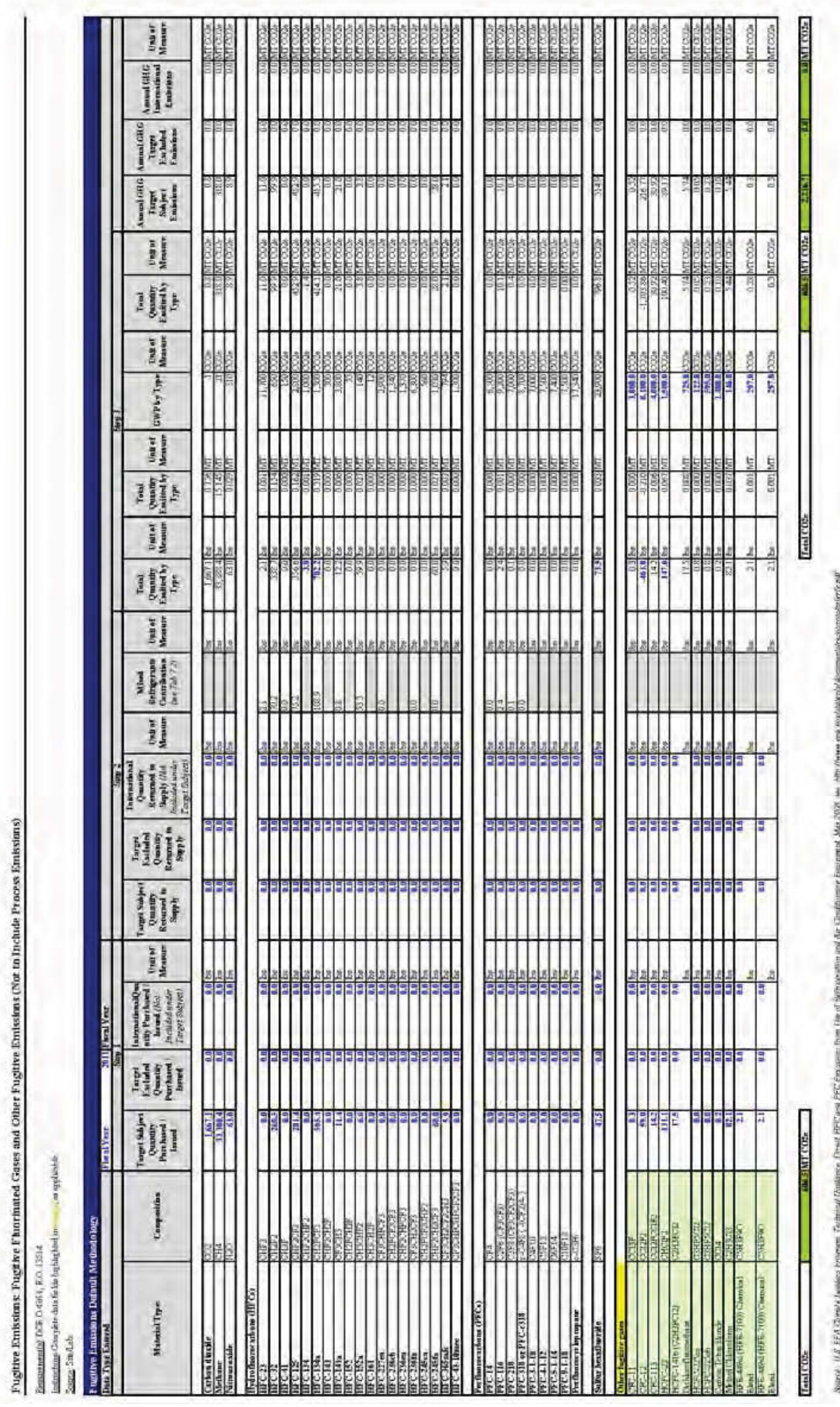




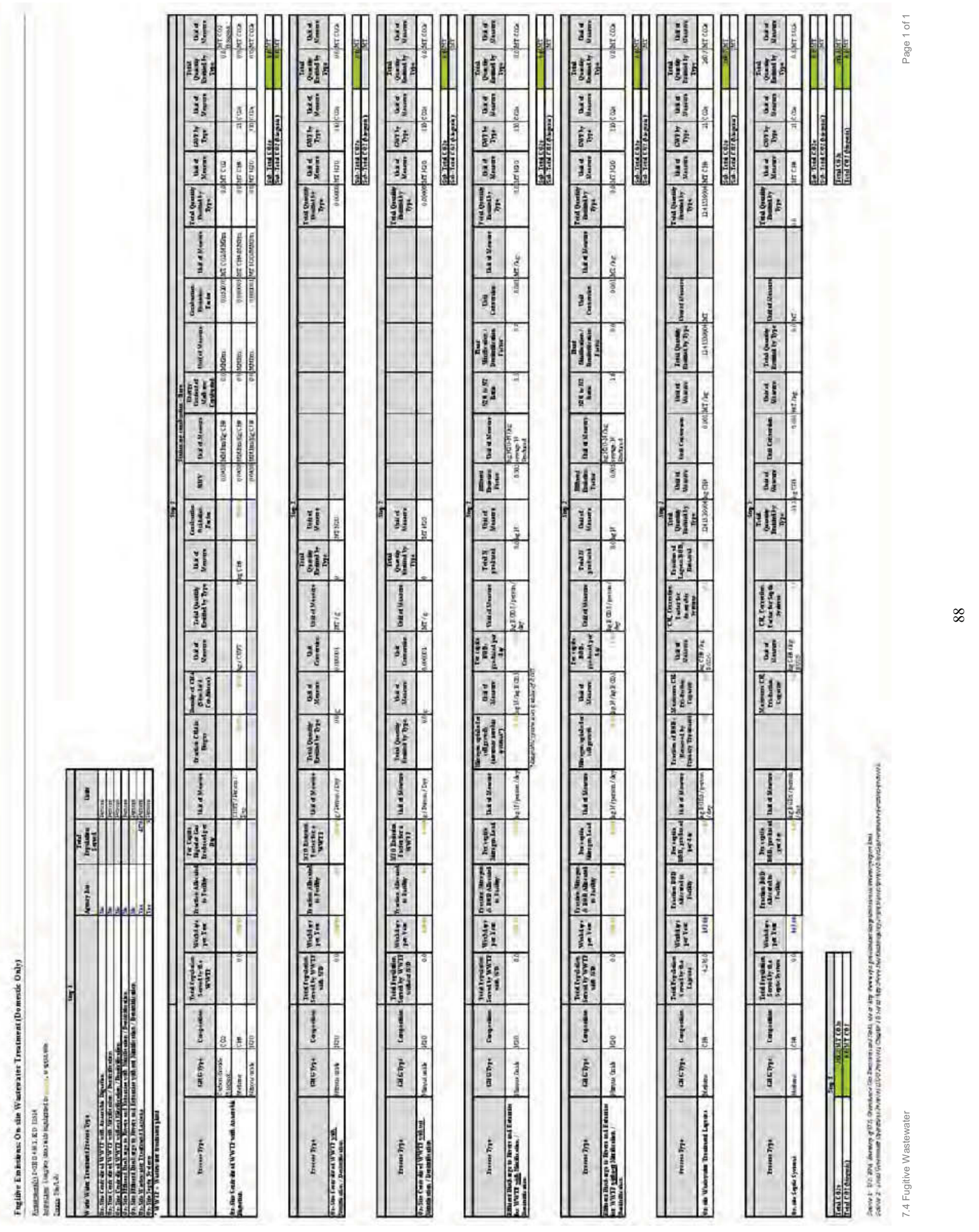









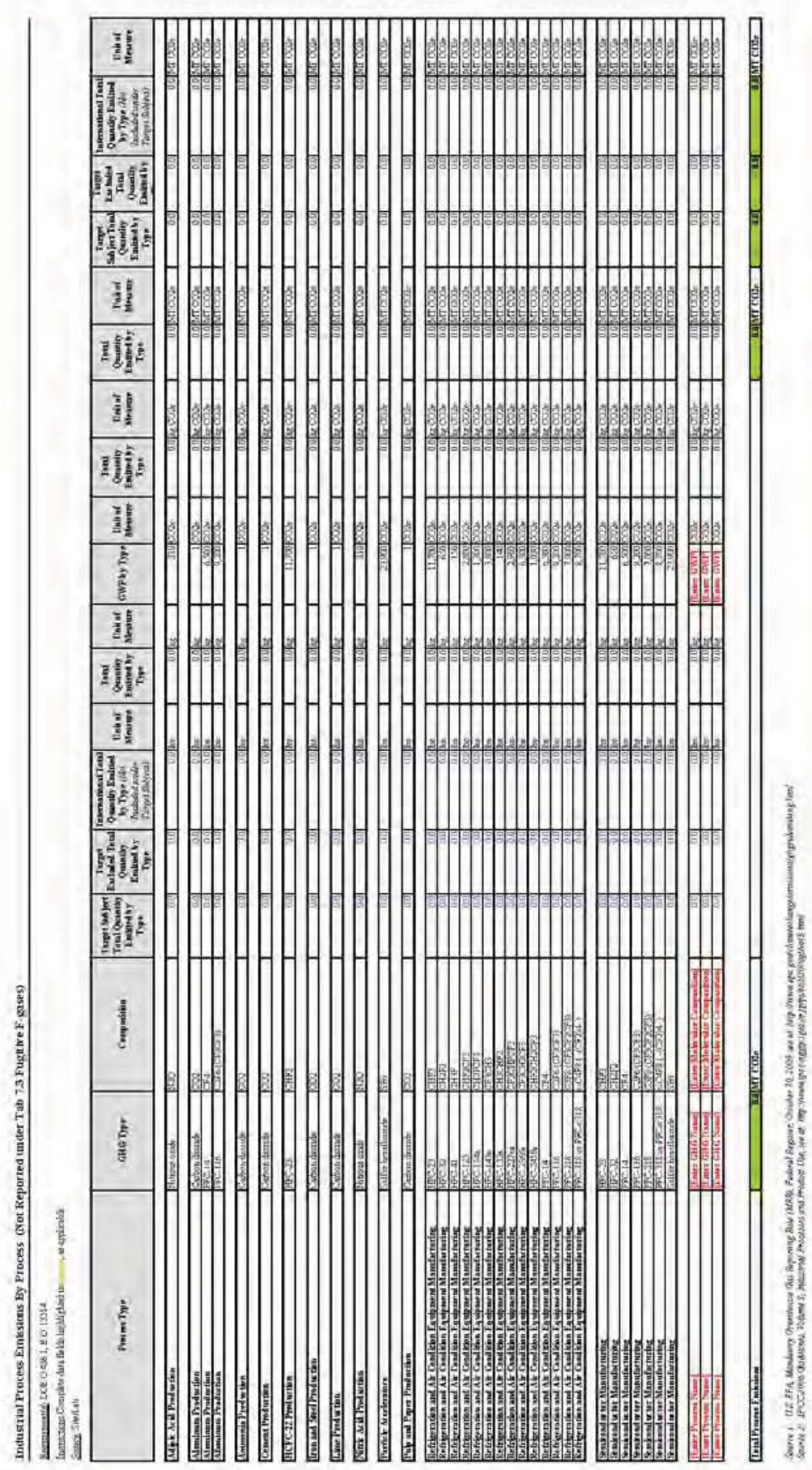



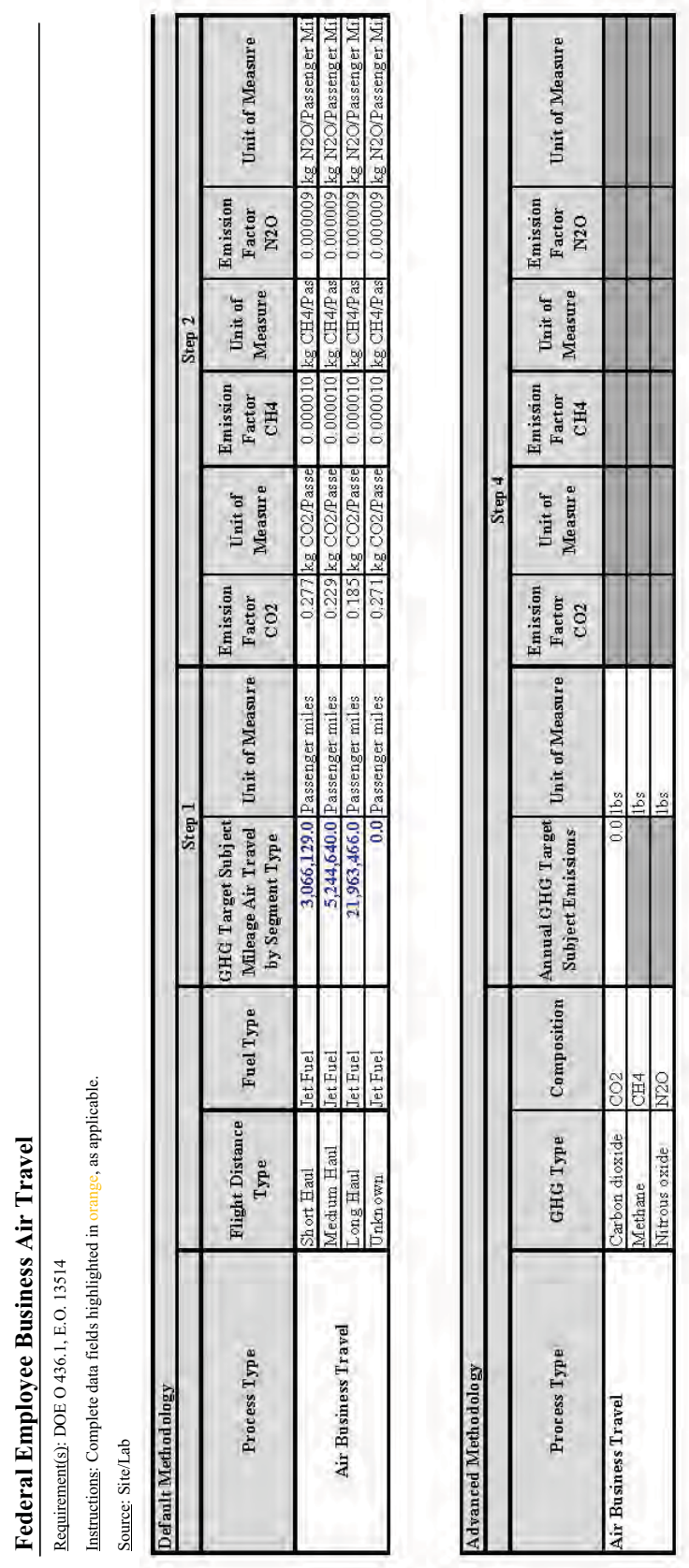

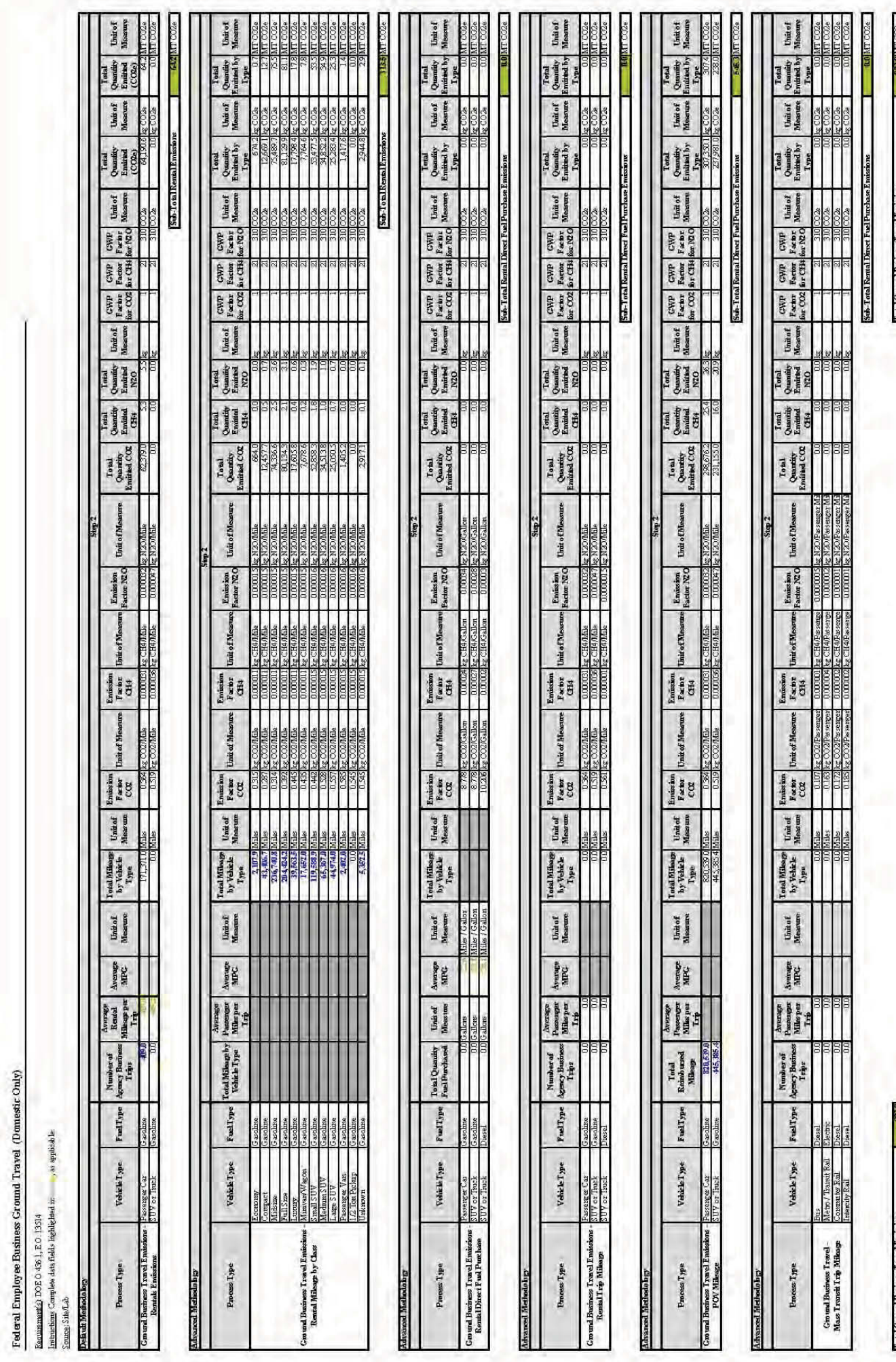

周 

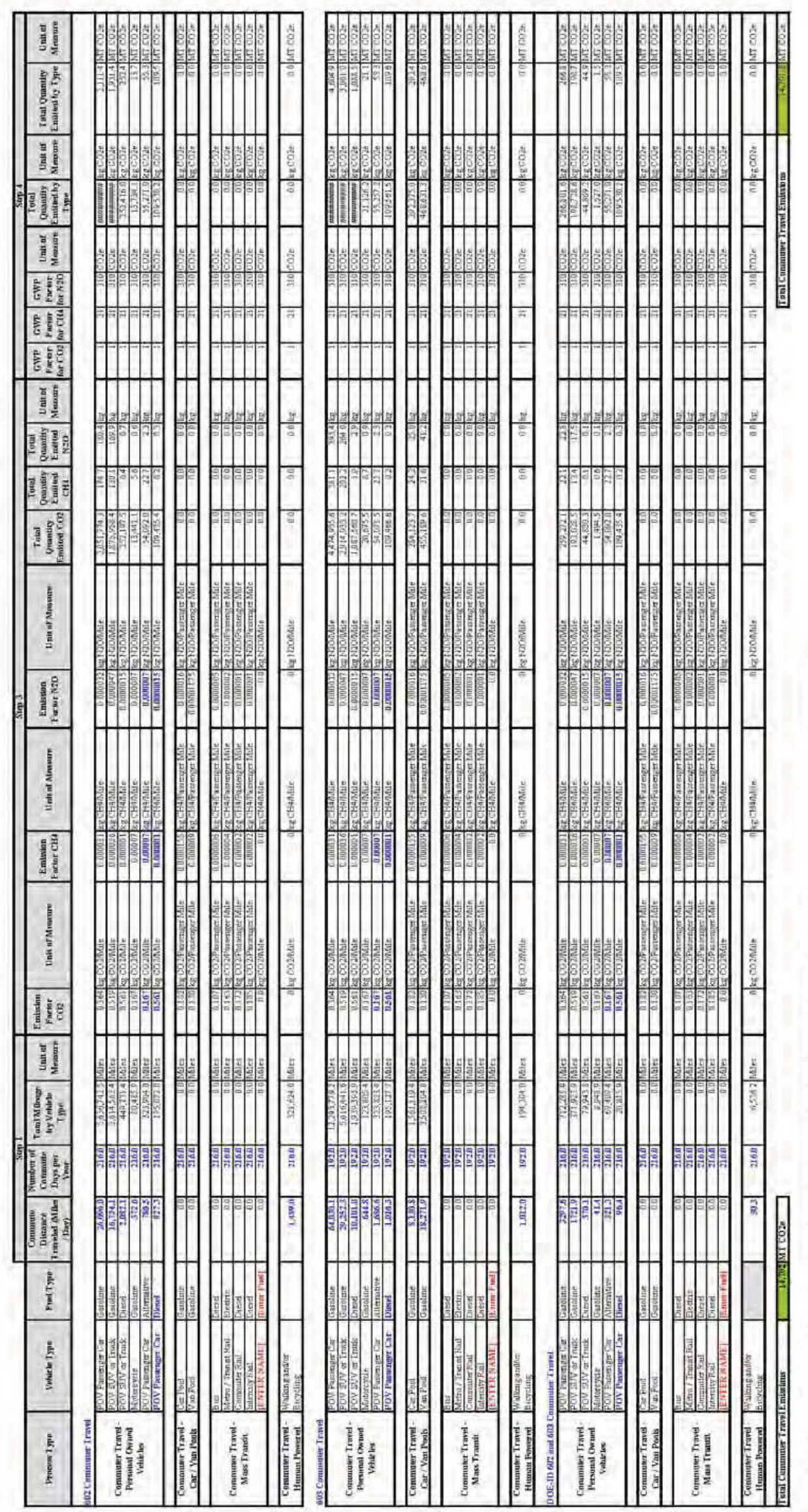


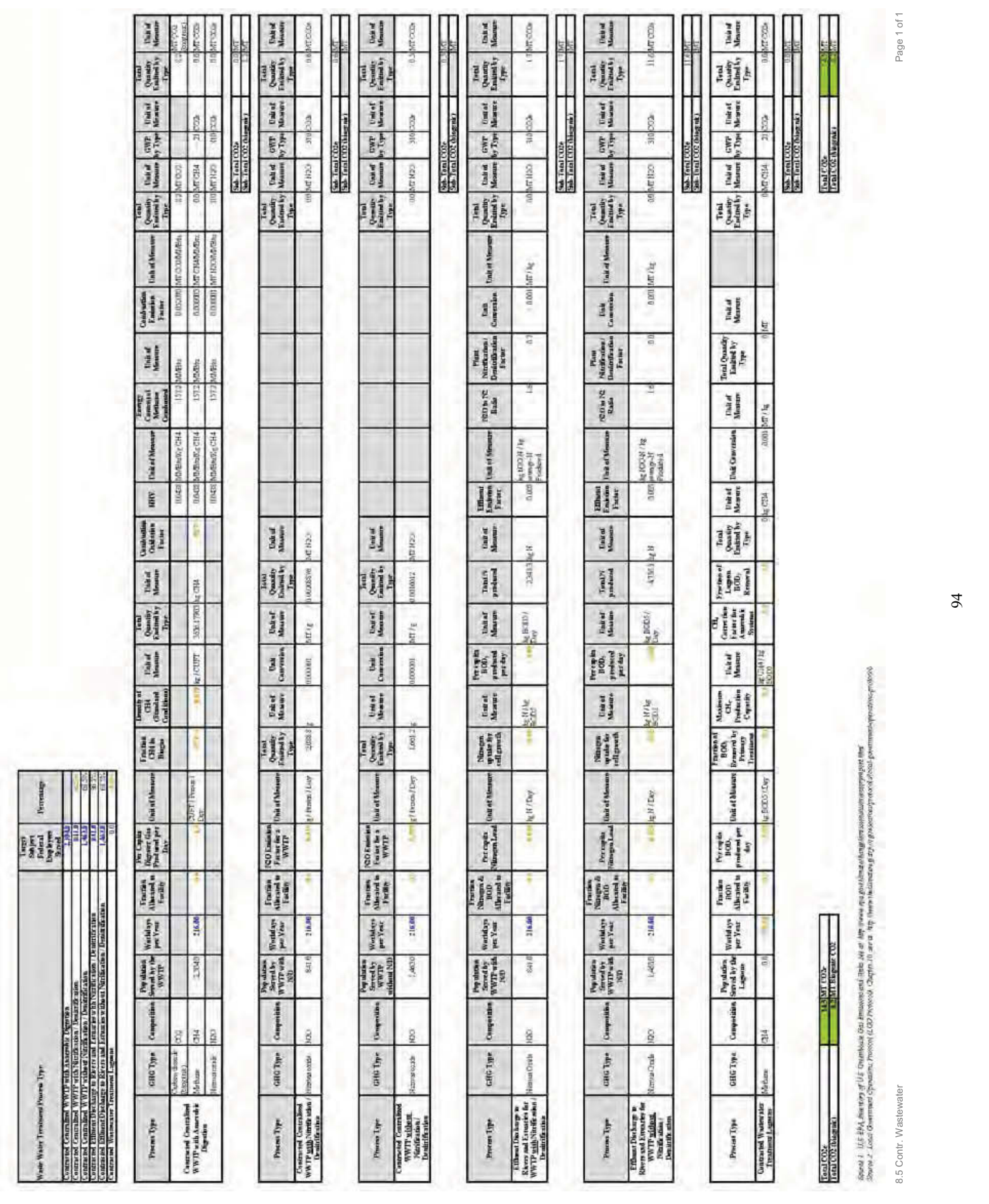




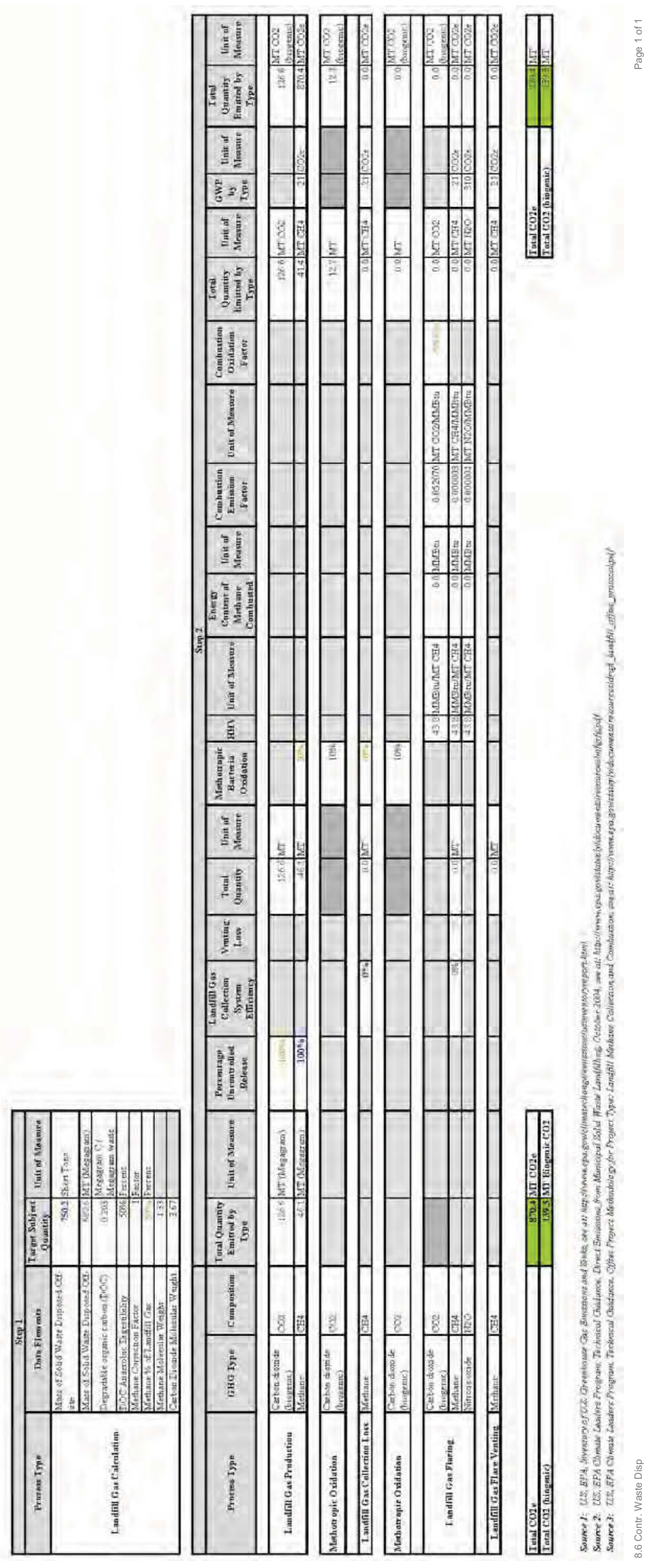




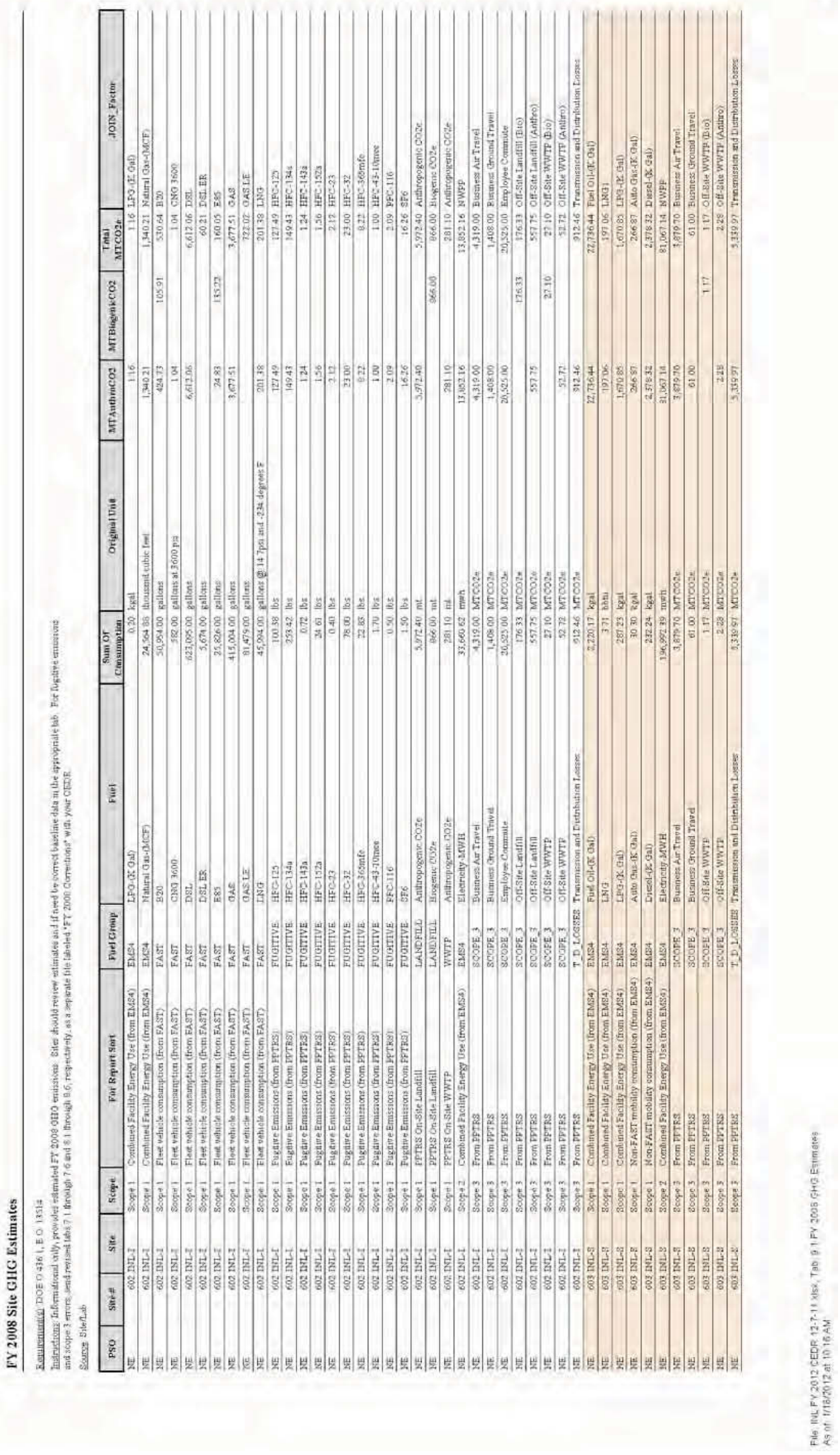

